Portland State University

PDXScholar

Fall 12-28-2017

\title{
The Downward Spiral: Postmodern Consciousness as Buddhist Metaphysics in the Dark Souls Video Game Series
}

Paolo Xavier Machado Menuez

Portland State University

Follow this and additional works at: https://pdxscholar.library.pdx.edu/open_access_etds

Part of the Japanese Studies Commons

Let us know how access to this document benefits you.

Recommended Citation

Menuez, Paolo Xavier Machado, "The Downward Spiral: Postmodern Consciousness as Buddhist Metaphysics in the Dark Souls Video Game Series" (2017). Dissertations and Theses. Paper 4161. https://doi.org/10.15760/etd.6049

This Thesis is brought to you for free and open access. It has been accepted for inclusion in Dissertations and Theses by an authorized administrator of PDXScholar. Please contact us if we can make this document more accessible: pdxscholar@pdx.edu. 
The Downward Spiral: Postmodern Consciousness as Buddhist Metaphysics in the Dark Souls Video Game Series

by

Paolo Xavier Machado Menuez

A thesis submitted in partial fulfillment of the requirements for the degree of

\author{
Master of Arts \\ in \\ World Languages and Literatures: Japanese
}

Thesis Committee:

Jon Holt, Chair

Laurence Kominz

Suwako Watanabe

Portland State University

2017 


\begin{abstract}
This paper is about locating the meaning of a series of games known as the Dark Souls series in relation to contemporary social conditions in Japan. I argue that the game should be thought of as an emblem of the current cultural zeitgeist, in a similar way one might identify something like Jack Kerouac's The Dharma Bums as an emblem of the counter cultural 60s. I argue that the Dark Souls series expresses in allegorical form an anxiety about living in a time where the meaning of our everyday actions and even society itself has become significantly destabilized. It does this through a fractured approach to story-telling, that is interspersed with Buddhist metaphysics and wrapped up in macabre, gothic aesthetic depicting the last gasping breath of a once great kingdom. This expression of contemporary social anxiety is connected to the discourse of postmodernity in Japan. Through looking at these games as a feedback loop between text, environment and ludic system, I connect the main conceptual motifs that structure the games as a whole with Osawa Masachi's concept of the post-fictional era and Hiroki Azuma's definition of the otaku.
\end{abstract}




\section{TABLE OF CONTENTS}

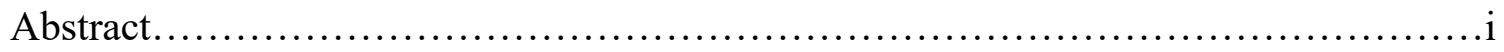

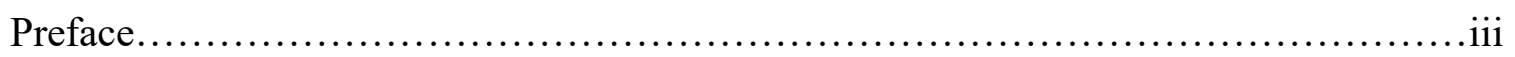

Chapter 1

Introduction................................................................

Chapter 2

Hard Work and the Magic Cycle of Play.........................................60

Chapter 3

Mappō, Dead Narratives, and Uncanny Others.................................. 72

Chapter 4

Postmodern Consciousness, Mappō Consciousness...................................89

Chapter 5

What's the Point of Being a Hero?

Conclusion........................................................... 132

References........................................................... 137

Appendix: Figures......... ............................................. 142 


\section{PREFACE}

As a field, the Humanities is predicated on the idea that there is more to art and literature then just art appreciation. When we read the works of Natsume Soseki or Mishima Yukio, professor and student do not merely read as fans swooning over the panache and grace of their prose, but as critics teasing out the deep kernels of thought that structure the text. Read enough of such works in this manner and something greater emerges: a great stream of ideas spanning eras and cultures where the bounty of life's mystery, beauty, terror and tragedy are encountered as eddies and flows of the human experience. Literature is the guide, as the old cliché goes, to the life well-lived: a mirror reflecting where we are and a map that gives clarity to where we wander. In short, great works are there to make us stronger. They give us clarity to face life's paradox's and the courage to bear its weight. We study literature to get at something common in the human experience and make it our own. This, at least, is the ideal and founding principle of the Humanities.

But if we take this to be true, can we really say that this encounter is something exclusive to literature? Is there something about the written word that has a special power to catalyze such reflection in a way that other mediums cannot? In the end, literature is merely a series of stories, but stories do not belong to one medium alone. Stories are transmedial. They can be told orally, in print, through dance, through images and perhaps in ways not yet conceived of. This is because stories live first and foremost in the deep structures of the human mind, and different mediums allow different aspects of these structures to reveal themselves to us. Stories are central to human life, they give coherence and meaning not only to our society but to the happenings of our personal life. 
Stories are the substrate of individual identity, and there is perhaps a sense that the human capacity to render our experiences as a story is connected to our ability to perceive time. After all, what is story but the organization and editing of time in a meaningful way? In short, by studying stories, and in particular the stories that have common purchase in societal imagination, we gain a small measure of access into the deepest recesses of the human psyche. When we approach this dark territory we come closer to ourselves, and perhaps there is a chance we might find something; something we forgot, something so absolutely necessary to our precarious existence it strikes tinder on a powder keg beneath our feet and our perception of the world is born anew in the conflagration.

New mediums tend to have a rough go at it in the university as each one must fight its way uphill past the arbiters of high-culture. It was true of film and photography at the outset of the twentieth century, and it is true of comics, television and video games today, but how impoverished would the Humanities be if we simply dismissed the works of Mizoguchi Kenji on the grounds that they belong to the wrong medium? What is there to gain by privileging the study of one medium over all others? This is prejudice of the worst sort, and we are all the poorer for such arbitrary judgements. We cut ourselves off from new perspectives on those deep structures that animate us. Stories live in the newer mediums as surely as any other, and furthermore, to those raised in a world dominated by these new mediums, the stories discovered therein are enthralling, moving and deeply meaningful. All that being said, the way stories are experienced in video games are profoundly different from any other medium, and it is precisely this radical difference that makes studying them so important. It reflects a new way of perceiving and valuing things in the world. We do not live in a world where technology is a tool; technology is 
an environment we dwell in. Where film and television were the mediums native to the industrial age, video games are the medium native to the digital age. Video games are not niche. The revenue generated by this industry globally outpaces film and print by a fair margin. There is something in them that resonates powerfully with literally billions of people. This alone makes their study a pressing matter.

That being said, it is important to recognize that video games are a medium in their infancy. Just like the early films were simply representations of basic phenomenatrains speeding at the screen or horses galloping in slow motion- there is undoubtedly an ocean of untapped potential in the medium of video games. Furthermore, we cannot yet appreciate this medium as whole endeavor the way we can literature. There is simply not enough hindsight to understand the role video games may play in our culture and the effect they will have in shaping our values and character. I will not argue here for the creation of a new canon of works. It is far too early for that, and moreover, a process of popular canonization has long been in the works. The games under investigation here, the Dark Souls series, has already been canonized in this fashion. It enjoys a status in which other games of its type are measured and those that share its design principles are referred to as "souls-like" perhaps in a fashion similar to the way many works of literature or film—regardless of whether it is appropriate — are described as "Kafka-esque." However, I will not attempt to assess the game as a great work in the sense that the study of this particular series should be institutionalized. I believe these games have been canonized not simply because they are "fun," but because they deal directly with the problems, anxieties and challenges that face contemporary Japan and its younger generations. This 
is the question we will ask: what is reflected in these games that resonates so deeply across cultures and with fans and critic alike?

I will limit the discussion here primarily to Japan, but I believe the lessons I gleaned while investigating this game have global implications. For the time beings, these implications will be left as just that. At its core, playing a game for its story is a paradoxical affair. The internal components of a game, as an embodied system of code and as a vehicle for different kinds of narrative (textual, visual, aural), place a swirling array of competing demands on the player. This paradox is as unresolved in Dark Souls as it is in almost all other games, but the series has achieved a rare level of consonance between these competing elements that perhaps speaks directly to the experience of the digital world in everyday life. It is my hope that my analysis here, if only in preliminary and incomplete fashion, can serve as opportunity to reflect on where society is going, what new value structures are emerging and what the business of literary interpretation, or in this case ludic interpretation, can do to shed light on these issues. 


\section{CHAPTER 1: INTRODUCTION}

This paper was written with the purpose of assessing the meaning of a series of games known as the Dark Souls series in relation to contemporary social conditions in Japan. I argue that the Dark Souls series expresses in allegorical form an anxiety about living in a time where the meaning of our everyday actions and even society itself has become significantly destabilized. It does this through a fractured approach to storytelling that is interspersed with Buddhist metaphysics and wrapped up in a macabre, gothic aesthetic depicting the last gasping breath of a once great kingdom. The anxiety expressed in this allegory is deeply connected with the discourse of postmodernity in Japan, specifically the notion that the project of modernity has failed and that the narrative of progress is corrupt. In my paper, I argue that this discourse is represented in Dark Souls through the simulation of a classic hero's journey that the game ultimately subverts by denying the player a sense of heroic accomplishment and replacing it with a deep sense of ambiguity and uncertainty.

The Dark Souls series is a third-person action RPG whose core mechanic is centered around the exploration of a ruined world. It was developed by the acclaimed Japanese video game company FromSoftware under the direction of its president Hidetaka Miyazaki. The first game was released in September of 2011 and the third in April of 2016. It is a game of unforgiving difficulty, set in an apocalyptic fantasy world that demands the player overcome many complex kinesthetic tasks. A key aspect of the game is its distinct lack of concrete narrative exposition. However, there is a core of conceptual motifs that bind the games together. There is always a kingdom ruined by a 
"curse of undeath" and there is always an injunction by mysterious figures for the player to kill the old gods and use their souls to "link the fire." This process is initially construed as a world revivification process in the first game, but it is revealed in the second and third game as simply a downward spiral of inevitable decay.

Millions of copies have sold worldwide and all three installments have enjoyed nearly-universal critical acclaim abroad, earning numerous "game of the year" distinctions and reams of other industry accolades. It has exerted such a heavy influence on contemporary game design that many games deploying similar design are often referred to as "souls-like" or "soulsian." This has become something of a cliché much in same way that works of literature sporting a trace of the surreal or existential can be described as "Kafka-esque." My explanation for this stature is not that the game is a lot of "fun," but because it has something powerful to communicate about the world we live in today that resonates with those whose view of society aligns with the postmodern critiques of modernity mentioned above.

The core argument of this paper is that the Dark Souls series embodies the experience of living with a postmodern consciousness of the world. This term "postmodern consciousness" is a general appellation I have appropriated to summarize postmodern thought. However, I specifically focus on the Japanese branch with the writings of sociologist Osawa Masachi, cultural critic Azumi Hiroki, literary scholar Motoko Tanaka and novelist Murakami Haruki. Starting with Francois Lyotard—who first coined the term "postmodern"- the central claim orienting the disparate branches of postmodern thought is that the "grand narratives" that once served to orient society have 
become hopelessly fractured and beyond repair. Osawa and other thinkers have picked up this line of reasoning and have applied it to a specifically Japanese context. They argue that the fracturing of the grand narratives of Japan's postwar period has instilled nihilistic behaviors in the younger generations that manifests in a turn away from political causes and community engagement to excessive consumerism and a kind of media-worship manifested in the figure of the otaku. In some extreme cases, this otaku-ism can lead to pathological behaviors such as the terrorism of the Aum Shinrikyō, but it is important to note that these thinkers consider such acts of violence as the outermost portion of a continuum of otaku-like behaviors and not as categorically different. From postmodern thinkers like Osawa and Azuma, I distill postmodern consciousness into two basic features: 1. a rejection or inability to accept grand narratives and ideologies as a source of meaning 2. an increasing sense of anxiety and hostility towards "the Other." The Other in this case refers to the classic philosophical binary between the Subject and the Other; in other words, the relation between the self and all other selves encountered in the world. The fracturing of grand narratives has weakened the communal bonds and fellow-feeling that depend on those narratives for their coherence and stability. It is this consciousness that is the main contemporary cultural element animating the Dark Souls series design and narrative.

However, it is by no means self-evident that postmodern consciousness is in fact a widespread cultural phenomenon in Japan. For this reason, I spend the first chapter tracing the precise manner in which grand narratives gradually broke down in Japanese history starting with post-war era and leading up to present. This makes it possible to see 
the development of postmodern consciousness and its expressions both in Japanese society and in the Dark Souls series. Without this crucial step, it is impossible to identify the postmodern consciousness that permeates this series.

In order to unearth the cultural roots of postmodern consciousness in Japan, I adopt Osawa's cultural zeitgeist theory that breaks the postwar period into three phases: the age of ideology (1945 - 1972), the age of fiction (1972 - 1995) and the post-fictional age (1995 -present). The basic point Osawa makes in his work is that the death of ideology—in essence, his term for "grand narrative"—stimulated new forms that ultimately alienated them from the ideological underpinnings of Japan's post-war society. Starting with the Red Army Coalition Incident (Rengō Akagun jiken ) ${ }^{1}$ in 1972, radical leftist politics gave way to an a-political, consumer hedonism. This resulted in the proliferation of sub-cultures oriented around conspicuous forms of consumption, especially with regard to fashion. However, for some, a desire for deeper meaning remained and this ultimately gave rise to new age cults, namely Aum Shinrikyō, that drew equally from traditional religions as they did from anime and manga to fill this need.

The Aum are important because they signify both the weakening of traditional faiths and ideologies as well as a growing intolerance to anything that they perceived as "other" to their hermetically sealed worldview. They also signify a kind paranoia about hostile others both impossibly far away, and right within their midst. For example, they believed that the Japanese government was controlled by a global Jewish-freemason

\footnotetext{
${ }^{1}$ Also known as the Asama Sansō incident
} 
conspiracy, and that their own lotus compound was filled with double agents. Their paranoid act of terrorism in 1995 was against this perceived Jewish other but ironically had the effect of spreading this very same paranoia in inverted form about Aum bogeymen lurking in schools, businesses and even the government. This notion of uncanny others is powerfully expressed in Dark Souls in the way it presents to the player a world of full of hostile individuals and groups - entities that are other to the player character-whose aims and practices are unintelligible. This also compounded through a system by which the player is always connected to the internet and open to invasion by other players.

Azuma adopts Osawa's zeitgeist, and posits a theory of "animalism". He states that because the postmodern age lacks grand narratives, people are left bereft of ideals and aspirations. They thus withdraw into a world centered on the fetishistic accumulation of signs which are added to a massive semiotic database and repurposed. His primary evidence for this is that the otaku of today are no longer interested in narrative. Instead, they merely enjoy identifying, re-mixing and expanding the components of the database. His prediction is that the activities of otaku, with their endless collecting of signs, are the vanguard of the culture at large and that succeeding generations will become increasingly more otaku-like in their own domains. The deeply ambiguous and sparse narrative present in Dark Souls reflects this trend in popular culture that Azuma identifies.

So how exactly does Dark Souls express postmodern consciousness through gameplay? I argue that it simulates a traditional heroes journey by furnishing us with a quest and a kingdom, but depriving us of any coherent way to understand the meaning of 
that quest. The game provides a world rich in visual detail, but utterly lacking in concrete exposition, putting the player in the role of archaeologist and forensic scientist. However, no solid interpretation is ever forthcoming; only more hints and fragments, some contradictory. This is referred to as "environmental story-telling," and it creates the most crucial point of contact between the game and postmodern thought; its rejection of a master narrative. There is the suggestion of "save the kingdom," but it is merely that: a suggestion primarily imparted by the conventions of the genre, not the narrative. It is never fully clear the meaning of what you are doing, and whose purpose it serves.

It is important to bear in mind that while a traditional lens of literary interpretation can be applied to the narrative of the Dark Souls series, there are numerous practical and theoretical problems encountered when one tries to interpret game mechanics as having an allegorical meaning. For this reason, I devote Chapter 2 to a literature review of contemporary critical theory regarding the study of games. Using the arguments of Espen Aarseth and other thinkers that have laid the foundations of the field, I argue that a "firstperson" phenomenological approach, combined with a more traditional literary analysis approach, is necessary to properly assess the potential meaning latent within a video game. This is done to establish a means by which to analyze the precise way the player is made to experience through grappling with the game's systems the two essential features of postmodern consciousness I have outlined above. I put this phenomenological approach into practice in chapter 3 where I explore a particularly potent fusion of textual narrative, environmental story-telling and gameplay that captures the essence of the game when looking at all its different elements as a unified experience. 
There is another stream of influence in the game besides postmodernism that informs the Dark Souls series and that is the Buddhist apocalyptic concept of mappō, or the end of the dharma. These two streams of influence overlap in intriguing ways and produce surprising parallels. Mappō was an extremely influential concept in the Kamakura period, which was like our own times a period of profound societal transformation. Mappō refers to the idea that the teachings of the buddha have lost their efficacy and people can no longer rely on their own efforts to attain enlightenment. What follows is that the clergy and monasteries become incontrovertibly corrupt and people subsequently become unable to leave samsara, trapped in a series of increasingly degraded reincarnations. I analyze the philosophical core of mappō in chapter 4 and demonstrate the way it aligns with postmodern discourse of Osawa and Azuma. Furthermore, I argue that, insofar as the Dark Souls series expresses postmodern consciousness, it is primarily expressed through the appropriation of this Buddhist eschatological concept. Both postmodern thought and mappō express the fear that things will only get worse, and that human efforts are incapable of changing the result.

In chapter 5, I return to a mix of phenomenological and literary analysis to demonstrate how the mappō concept, along with an eclectic mix of Buddhist metaphysics, function as the core components that structure the game as a fictional world despite the games' decidedly Western aesthetic. These Buddhist elements all work to reveal the game world as trapped in a cycle of increasingly degraded reincarnations, and the quest of the player as being fundamentally an act in futility that only serves to drive this cycle of suffering. I argue that the incorporation of Buddhist metaphysics ultimately 
works to express Azuma's conclusion that postmodern world with its dead narratives and uncanny others is inexorably leading to a general societal descent into "animalization." Even though Dark Souls is a game whose aesthetic is clearly derived from a medieval, European, fantasy palette, it is permeated with the logic of mappō and thus the game is deeply syncretic, expressing a postmodern sentiment by appropriating and refashioning Buddhist metaphysics, all under a veneer of gothic knights questing in ruined castles.

\section{NARRATIVES OF DECAY}

For the past few decades, Japan has become something of a byword for stagnation. This is in no small part due to the "miracle" Japanese experience from the 1970s into the 1980s, and their startling fall from grace that has left the country in a seemingly listless spin ever since. Here in America, when Japan is mentioned in publications like the New York Times or the Wall Street Journal, it is rarely positive and tends to circle around the same narrow band of topics: the population ages while the youth commit suicide; the currency deflates and corporate goliaths - Sony, Toyota and Toshiba — are felled by leaner competition; nuclear fuel is still seeping into the ground water in Fukushima but still no one is accountable, and so on and so forth, each prognosis more dire than the last. In the West, Japan as a crumbling empire has been a narrative long in circulation. The impression of decay is so strong, it seems only inertia keeps everything working, to the point where one forgets Japan is still one of the wealthiest, most affluent and technologically advanced nations in the world, still ahead of many of 
their Western European counterparts. This narrative of stagnation lives in Japan as well. As current Prime Minster Shinzo Abe's 2012 election slogan suggested: Nihon o torimodosu (Take back Japan). From whom and to where? With the "three arrows" of his "Abenomics" agenda of economic reform he will save Japan from its own "shrunken mindset" (Sharp). If the 1980s were represented by the salary-man—fanatically hardworking and starved for corporate ascendance—recent years have replaced this archetype with far more impotent ones: sōshoku danshi, ${ }^{2}$ NEETs (young adults Not Employed in Education or Training), hikikomori (social shut-in) and other deleterious monikers. To be sure, the economic and cultural problems of Japan are as a real as they are in any other nation, but the force of this narrative has taken on a life of its own beyond the reality. This "shrunken" mindset of a world gone wrong and its accompanying cultural expressions I will refer to as postmodern consciousness. This consciousness must be held distinct from postmodern philosophy proper, as the philosophy itself is merely one of many affective responses to the overall narrative of decay surrounding Japan.

At its core, postmodern consciousness is an anxiety born out the perceptionconscious or unconscious - that human society has reached a point of incontrovertible decay. Given the broad, cultural discourse surrounding Japan's economic and cultural degeneration as outlined above, postmodern consciousness has been enjoying a central place in the Japanese cultural psyche. It is therefore not surprising that these narratives of

\footnotetext{
${ }^{2}$ The term, sōshoku danshi (literally: herbivore men) refers to young men that have no interest in getting married or finding a girlfriend. They have been described by philosopher, Masahiro Morioka as "kind and gentle men who, without being bound by manliness, do not pursue romantic relationships voraciously and have no aptitude for being hurt or hurting others" (Morioka, 7). Their indifference toward the other sex is often cited as being a primary cause in the declining birth rate.
} 
stagnation arising from postmodern consciousness also find powerful and diverse expression in Japan's popular media. Although there are many examples from which to draw, the game Dark Souls (FromSoftware, 2010), and all its sequels, is the example par excellence of the "shrunken" mindset that animates this narrative of decay. To understand how it functions in this way, we must look not only at the narrative but also how Dark Souls exists relative to other video games of the same genre. Dark Souls belongs to the genre of video game known as the role-playing game (hereafter RPG). RPGs are usually open-ended simulations of a fantasy world where the player gets to explore territory, collect treasures and defeat monsters. Typically, a player creates a character-an avatar for themselves in the game world - with which they embark on quests whose ultimate object often involves saving something (kingdom, plane of existence, princess, etc.) from annihilation. Another essential feature of most RPGs is the concept of growth. Although there are many design schemas and metaphors employed to simulate the process of growth, typically a player's avatar accumulates experience points by defeating monsters, and through the accumulation of such points, "levels up." Through the leveling-up process, the player unlocks abilities and their avatar becomes more powerful. In general, RPGs tend to function as a simulation of the hero's journey pattern common amongst myths in many cultures: young, unformed person must leave the safe confines of their home, confront the danger of the unknown, overcome them, cultivate their latent potential and return, literally or figuratively, as a powerful and fully actualized person. In its basic design, Dark Souls is fairly traditional as an RPG. However, it has a number of narrative and ludic design choices that subvert numerous conventions of this 
decades-old genre. As a narrative, it can be read as both a political and cultural allegory that speaks directly to the experience of living in an ailing civilization whose ideological narratives have lost their appeal and coherence. It is also at the forefront of a burgeoning new genre: Post-Apocalyptic Fantasy. In this game, the kingdom is overrun, the heroes are all dead or corrupt, there is no one to save and the biggest threat to your existence are others who survive alongside you in the wreckage. Community is impossible. The fundamental ontological condition is interminable failure and the "hero" is merely doomed to endure it. Not even death can absolve the characters within this work from their burdens and the meaning and objective of the quest you've been tasked with are illdefined and ambiguous. Narrative is barely even present. When the game begins, the player is merely dropped in an abandoned kingdom overrun with monsters and the undead, with no clear reason why things are the way they are or what they ought to do about it. What little narrative there is exists as minute fragments of text that only dispense tantalizing, and ultimately incomplete or contradictory, bits of information about the world. All these narrative elements pose serious challenges to established genre conventions, and therefore link it to the discourse of decay.

On the side of game design, Dark Souls has two features that make it standout. The first is that the game has been intentionally designed to be punishingly difficult. This is actually one of the primary sources of its appeal. The advertising tagline associated with the series in the West is "Prepare To Die" (NamcoBandai; video clip), and in Japan, the series is considered the premier example of shini gee, ${ }^{3}$ alluding to the countless

${ }^{3}$ Shini gee: A term roughly translatable as "death game" 
deaths the player will surely experience as they struggle with enormous, terrifying monsters far more powerful than the avatar the player creates. The other is that even though the game is primarily designed as a single-player experience-also a wellestablished convention of the RPG genre- the player is always connected to the internet. This was widely lauded by video games critics as an important innovation in the genre. In practice, this creates a tense situation where the player is always exposed to the "invasion" of other players, who will attempt to kill that player. There is a complex risk/reward system built into this interaction where the invader has much to gain by killing the other player, but much to lose should they fail.

In effect, the constant connection to the internet suffuses the game world with paranoia and danger. Other players are the most dangerous and unpredictable monsters a player can face in this game. Oftentimes invading players will lay in wait, striking at an inopportune moment when the other player cannot defend themselves, thereby reversing the much hard-earned progress of their hapless victim. We will explore the narrative and game system in detail, however, this basic sketch of the games begs the question: how could a game in which there is no hope of saving the kingdom, and that is punishingly difficult often to the point of being unfair have such appeal? But the game indeed has immense appeal, not only in Japan, but across Europe and North America. This also points to the way the design and narrative resonate with the experiences of a younger generation living in listless times.

The narrative of stagnation in the Japanese cultural sphere requires some further clarification. I contend that Dark Souls can be read as a political and cultural allegory for 
contemporary conditions in Japan. It is a postmodern inversion of the hero's journey: a simulation of a contaminated mythological fragment. It speaks directly to the feeling of listlessness and futility experienced by many young Japanese today as they attempt to navigate hulking institutions in terrible disrepair that are at best indifferent to their existence, and at worst, outright hostile. However, this allegory is not merely an economic one about living in the years after the "miracle" of the 1980s. It is equally about the social and psychological costs of living in a society where national, political and cultural narratives of the post-war era that once served as a kind of psychic bedrockgiving stability to individual and communal identities—-has lost much of their meaning and coherence.

The events that catalyzed this deterioration have their origin in 1995, the year of the Kobe earthquake and the sarin gas attacks. There is typically not much discussion within Western media about the significance of these events either culturally or politically, but amongst many Japanese intelligentsia, these events seem to mark a definitive break with modernity. In his book, Underground: The Tokyo Gas Attack and The Japanese Psyche, the famed novelist Haruki Murakami conducted a series of interviews with survivors of the sarin gas attacks and concluded that the aftermath of this event had irrevocably laid bare all the contradictions, flaws and inherent instability of Japanese society:

The Kobe Earthquake and the Tokyo gas attack of January and March 1995 are two of the gravest tragedies in Japan's postwar history. It is no exaggeration to say that there was a marked change in the Japanese consciousness "before" and "after" these events. These twin catastrophes will remain embedded in our psyche as two milestones in our life as a people. 
That two such cataclysmic events should come in quick succession was as startling as it was coincidental. Yet, arriving as they did at the time when Japan's "Bubble economy" burst, marking the end of those times of rampant excess, they ushered in a period of critical inquiry into the very roots of the Japanese state. It was as if these events had been lying in wait to ambush us. Common to both was an element of overwhelming violence: the one an inescapable natural calamity, the other an avoidable man-made disaster. (Murakami, 237)

Through the work of many such intellectuals like Murakami, 1995 has taken on a monolithic and immutable status: the gateway to a broken and dysfunctional age. The primary theorists that will be analyzed here-Azuma Hiroki, Osawa Masachi and Motoko Tanaka — all take 1995 as the departure into a dystopian present. The tone of these thinkers has a subtle post-apocalyptic undertone in its own right, as if we are living in a contaminated age that is beyond salvation. This too is part of the discourse of decay. There is a certain eschatological conviction about these thinkers that connects them to this discourse.

In any case, it is perhaps these disasters, more so than any economic ones, that are responsible for the "shrunken" mindset that the current prime minister hopes to eradicate. Despite the intervening decades, the events of 1995 function as the touchstone from which the feelings of anxiety and helplessness animating the allegory within Dark Souls has its source. The continued floundering of the economy, the ageing population, dwindling professional prospects for the younger generation and disasters like Fukushima have only compounded these negative emotions that these disasters initially provoked in 1995. Events like Fukushima have only helped to create a kind of legacy in Japanese consciousness. In recent years, the re-emergence of ultra-nationalist right-wing politics on the one hand and the social withdrawal of NEETS and hikimori on the other, form the 
outermost extreme and opposite affective responses to this same underlying cultural malaise. The political right is trying to resurrect the vitality of an imperial "Yamato" narrative by engaging in public brinksmanship with its real and perceived rivals (South Korea, China, North Korea), attempting to efface the violence and moral repugnance of imperial Japan with historical revisionism, and attempting to restore war as a sovereign right by amending the constitution (article 9) to the state. For their part, the hikikomori surrender themselves to the pleasures of solitary diversions into the internet and other forms of private, digital gratification. There is no narrative for them to resurrect, no cause they can bear to join, not even a hobby group they can participate in. Communication with others is simply too difficult, and in their mind, too fraught with dangers.

My argument here is not that the Dark Souls series is the cause of these kinds of ills or even contributes to them, but rather it is a particularly potent expression of deep social anxieties circulating throughout the public awareness, especially younger generations for whom video games are a familiar medium. The continued popularity of the Dark Souls series functions as a kind of emblem of the societal turpitude that people feel in their everyday life. But what exactly are these anxieties present in Dark Souls and how do they manifest? Another way to ask this question is what are the basic elements of postmodern consciousness? There are two main elements that define the post 1995 era. 1. The rejection of political and social narratives that structured the post-war order and 2. A diffuse anxiety surrounding the Other that erodes trust and faith in social processes. The concept of the Other refers to one half of the binary between the self and all other selves encountered in the world. The extension of this concept is that of cultural otherness 
whereby one feels certain people to be akin to them and others to be alien. Japanese society is often viewed as having a very homogeneous national identity where fellow Japanese perceive each other as having the same culture, ethnicity and similar values. This in turn creates a strong sense of trust and community, but the inverse effect of this closeness is that outsiders are felt to be much more alien than they would be in more culturally diverse nations like the United States, Great Britain or France. What Osawa argues is that the terrorist activities of the Aum introduced into the general public the fear that lurking amongst their fellow Japanese was a potential threat. This fear is that of an uncanny Other who emerges suddenly to disrupt your life in a profound way, sometimes fatally. The rupture within this social fabric never truly mended and continues to be challenged up into the present. The element of paranoia regarding the uncanny Other is one of the main features that defines not only the atmosphere and narrative of Dark Souls, but also its mechanics as a game, especially its online component.

To understand how Dark Souls functions as an allegory that describes postmodern consciousness, we must trace the trajectory of decay within Japanese social conditions across the Post-war period. This is fundamentally a story where the modern narrative of progress - at root an inheritance from the West—-first gave rise to intense ideological struggles in the late 1960s, then dwindled into a kind of a-political hedonism in the 1980s, and finally, was well and truly shattered by a subtle nihilism that characterized the mentality of the Aum Shinrikyō in the years preceding the moments where five, righteous zealots of the faith punctured bags filled with Sarin gas with the sharp tips of their umbrellas. To do this, we will look at the work of the sociologist, Osawa Masachi. 
Masachi spent a good deal of his career attempting to answer the question of why the Aum did what they did. In his book, Kyoko no jidai no hate (The End of the Fictional Age) he argues the answer involves a fatal flaw within ideology itself: a dangerous and empty pattern of thought that leads to greater and greater levels of alienation within a world of one's personal design.

\section{$\underline{\text { IDEOLOGICAL AGE }}$}

Borrowing from the sociologist Mita Munesuke, Osawa Masachi divides the post-war era into two distinct phases. The first is what he terms risō no jidai (the age of ideology) and the second he calls kyokō no jidai (the age of fiction). The age of ideology begins in the 1960s and ends in 1972, and the age of fiction picks up there and ends in 1995. Osawa describes ideology and fiction as "potential worlds" (kanōsei no sekai) in that they both indicate our sense of the how the world is and how it ought to be.

However, although these two concepts are related at a fundamental level, they are different in a few important ways. Osawa argues that ideology is deeply involved with the world in its current state whereas fiction is totally divorced from it:

Ideology is a potential world within the future whose arrival can be expected, or hoped for, in the present. For this reason, ideology must exist as a causal extension of reality. By this definition, ideology is not a pure, potential world, rather it is one part of the real world in a broad sense. In contrast to this, fiction is a potential world that can exist without any relation to whether it will manifest within the real world, and so, is a pure anti-reality.

理想は、未来において現実に着地することが予期（期待）されているよう な可能世界である。だから、理想は、現実の因果的な延長上になくてなら ない。その意味では、理想は、純粋な可能世界ではなく、むしろ広義の現 実世界の一局面である。それにたいして、虚構は現実への着地ということ 
についてさしあたって無関連ありうる可能世界であり、それゆえ純粋な反 現実である。(Osawa, 41)

Leaving aside for the moment the exact way in which fiction alienates us from reality, the age of ideology in Japan is characterized in large part by the looming specter of the cold war. Where much of Asia existed under the Soviet umbrella, Japan existed under the auspices of the U.S. and thus was ideologically committed to democracy and economic liberalism. During the 1960s, Japan flourished in nearly every regard under these conditions: scientifically, infrastructurally, economically, culturally, etc. Osawa calls the 1960s the golden age of ideology, and points to home appliances as popular ideology given physical form:

In the popular sphere, the golden age of the ideological age was the 1960s. Of course, this coincides with a period of accelerated growth in Japan. During this time, the electrical appliances that were in overwhelming demand by the general populace gave physical expression to popular ideals...These ideals were not embraced because there was such progress in technology, science and economic growth, but just the opposite: it is precisely because people were so widely taken in by ideals that presented themselves as a potential reality that the economy was able to grow and science and technology advanced.

理想の時代の、大衆的な水準で黄金期は、1960 年代である。もちろん、 これは、高度成長期にあたる。この時期、たとえば、国民の圧倒的な大多 数によって広範に欲求された家電製品が、大衆的理想に物質的な表現を与 えた...経済成長や科学・技術の進歩があったから理想が抱かれたのではな く、逆に、理想が可能的現実として広く（世界規模で）信憑されたが党 に、経済が成長することができ、また科学や技術進歩していると感受され たのである。(Osawa, 44)

Optimism and desire for a better (materially enriched) future was the guidepost of the era and this very optimism itself reflected an ideological embrace of the American model that 
fueled the transition from a devastated Japan to a flourishing one. Osawa grounds this development in the obsession for a potential world. In his book Embracing Defeat, John Dower powerfully illustrates an acute manifestation of this embrace in the years immediately following the surrender with his analysis of the panpan girl-young women who willingly courted and engaged American GIs during the occupation:

In those years of acute hunger and scarcity, the material comforts of the Americans was simply staggering to behold. What made America "great" was that it was so rich; and, for many what made "democracy" appealing was that it apparently was the way to become prosperous. Among ordinary people, no group tapped the material treasures of conquerors as blatantly as the panpan. They were the recipients of goods from the U.S. military exchange posts that in those impoverished days truly seemed like treasure houses from a magic land: crammed not only with basic foodstuffs, but with liquor and cigarettes, sweets and delicacies, voluptuously decadent feminine things such as lipstick and nylon stockings. (Dower, 136)

By the late 1960s, the ideological vision presented by the American occupation force had largely lived up to its promise in a very tangible way and ordinary Japanese were beginning to reap the benefits of economic development in the form of amenities, consumer electronics, conveniences and all the trappings that go with a modern, industrialized nation. Osawa argues that this was when ideology was functioning at its smoothest within society. Despite whatever ideological conflict there may have been, people wholly embraced ideology as their ideal "potential world" and worked towards that future, whether they be Marxists or Capitalists. ${ }^{4}$ It is crucial to note, however, that despite the growth of the 1960s, it was still a time of deprivation for many Japanese. What made the 1960s the ideological age is not the relative prosperity itself, but the

\footnotetext{
${ }^{4}$ Osawa points to Sakamoto Kyû's "Ue ni muite arukō" as the song most emblematic of this optimism, he notes that the pop music of the day eschewed the quasi-modern yona-nuki scale and became fully westernized.
} 
promise of that prosperity, and a general faith that the post-war order was indeed heading in that direction. Ordinary Japanese tenaciously clung to this vision. This was the popular ideology of the time: the promise of cars, radios, pop music, easy access to food and all the comforts and material pleasures that were absent in the total despair, suffering, and devastation of the years immediately following the surrender.

However, Osawa argues that this embrace of ideology eventually led to a transformation of ideology into what he terms "fiction." This has to do with an inherent instability within the structure of ideology itself and not necessarily with the particulars of Japan's ideological establishment. Osawa speaks of ideology in the broadest possible terms, but he boils down the motivation that drives ideology to a single principle that he borrows from Buddhism: hinbyōsō. This term can be loosely translated as "worldly troubles" which are identified as poverty, sickness, and strife. He divides ideology from fiction primarily on the basis that ideology is oriented in a struggle against hinbyōsō. In other words, most ideologies have some promise of salvation from worldly troubles. This salvation is always necessarily in the future, but a conviction in its attainment keeps it stable and prompts concrete actions in the world taken towards it. This is true of most world religions, especially the confessional ones, but it is also true of secular concepts like Capitalism (free-market $=$ prosperity and liberty for all) and Marxism (abolition of property $/$ class $=$ salvation from inequity). However, there is a paradox at work in the relation between ideals and hinbyōsō:

The ideological age was a period where the entirety of society was alienated into ideals. In such a time, the worst one could suffer was to be indefinitely alienated from those ideals. In other words, people experienced a double alienation in their relation to ideology. Hinbyōsō represents an inescapable condition where the 
realization and contact with our ideals is severely problematized and we are unavoidably alienated from them in perpetuity. The suffering that arises from this alienation can only be resolved by renewed faith in our ideals insofar as the probability of their realization seems sufficiently probable to us. This is only possible as long as we are already alienated into ideology.

理想の時代とは、社会が全体として理想へと疎外されている時代である。 このような時代において、最大の不幸とは、理想から永続的に踈外される こと、つまり理想との関係において二重に疎外されることである。「貧病 争」は、理想への到達・接近が著しく困難になりうるような一理想からの 永続的な疎外を余儀なくするような一宿命的な環境条件を代表している。 不幸は、一すでに理想への疎外によって条件づけられている以上は一、到 達の蓋然性が十分に高い現実性として理想を回復することによってしか、 解消されない。(Osawa, 45)

What Osawa points out here is that there is an interpretive loop between the experience of suffering and the promise of salvation that is mutually reinforcing. Hinbyōsō, by definition, alienates people from the salvational promises of their respective ideologies, but that suffering can only be eliminated through revivification of ideals. Suffering tends not to cause people of faith to lose their faith, but rather stimulates them to interpret their suffering in terms of the narrative they already subscribe to. Making suffering meaningful is a coping mechanism often deployed to deal with tragic events in our lives. Paradoxically, this means that hinbyōsō can strengthen ideological conviction even when we are extremely distant from the potential world promised within ideology. Taken to an extreme, when our faith in the potential world is very strong we become "alienated" within that ideology and view the world only through the narrow lens of the interpretation afforded therein. This reflects the drive towards dogmatism and orthodoxy, and in such a state, hinbyōsō only serves as fuel for the ideological engine. However, the crucial 
component to this loop lies somewhat beyond it; somehow we must continue to believe that the potential world is possible. Osawa's fictional age sketches the collapse of this belief as a general occurrence amongst the mass of ordinary Japanese. However, this collapse is not to be confused with the kind of loss of faith where a devout Catholic becomes an advocate of atheism or a committed capitalist is reformed and born-again as a Marxist revolutionary. This is merely the swapping of one ideology for another. The underlying structure and orientation remain the same. The turn from ideology to fiction represents a new sort of alienation that is one step away from the loop between hinbyōso and ideology. It is a step away from the world itself.

Osawa brings up numerous examples to show how during the 1980s the ideological map of Japan became increasingly detached from large-scale narratives (Capitalism versus Communism) and gave rise to the shinjinrui, the otaku and ultimately, the Aum Shinrikyō cult and the sarin gas attacks of 1994-1995. What is crucial to note, however, is that in all these cases, whether it be Islam or Marxism, ideologies are intimately intertwined with the practical problems of the world in its current state. The projected potential world is only intelligible by virtue of this contrast. It is in this vital relation to hinbyōsō that ideology and fiction part ways. For Osawa, the movement from ideology to fiction was catalyzed by the profound disappointment in the wake of the political activism of the 1960s. Though Osawa argues that the 1960s were the time when ideology functioned at its smoothest, this does not mean that this era was a time free of ideological strife. On the contrary, in political terms, the late 1960s in Japan were marked by civil unrest. The idea of ideology functioning smoothly during the 1960s is not meant 
to signify political harmony, but rather the capacity of individuals to give themselves wholly and completely over to the narratives that structured their particular ideological position.

The 1960s was marked by numerous student movements that reflected the widespread political galvanization in Japan at the time. Many these movements were largely directed at protesting the Japanese government's support of the Vietnam War among other issues, but indirectly they amounted to a kind of resistance toward American influence over Japanese foreign policy. Anti-imperialist and anti-American sentiments were primarily stimulated by the Japanese Communist party. They created the Zengakuren (National Federation of Student Self-Government), an organization that was critical in creating a widespread culture of the far-left amongst university students (Hane, 465). Ultimately, these movements degenerated into violent scuffles with the police where protesters and police alike were maimed, injured and sometimes killed:

Student demonstrations started with protests against tuition increase in the mid1960s in a number of Tokyo universities. All in all, 115 universities were confronted with student protests, demonstrations, and riots in 1968. Massive strikes were staged, barricades were built, and key buildings were occupied. Often professors were given the hotbox treatment and subjected to kangaroo courts run by militant students, who yelled and screamed at them to confess their sins. (Hane, 465)

The descent into violence also precipitated a decline in the coherence of the originally peaceful political agenda. Theses protest were cobbled together from a patchwork of leftist groups with very differing agendas, and some were far more radical than others. The combination of violence without a specific or coherent political demand ultimately led to these student movements sputtering out and collapsing, leaving a lasting sense of 
political disillusionment. Motoko Tanaka, building on Osawa's zeitgeists, sees the failure of two specific student movements, the Anpo and Zenkyoto movements, as a major component in bringing to a close the ideological age. The Zenkyoto movement was a particularly protracted incident that created a pattern of essentially siege warfare that was adopted by other student uprisings. This struggle began at the University of Tokyo when medical students demanded the abolition of the intern system. The oppressive attitude of the administration then evoked a university-wide controversy. In July 1968, students formed Zenkyoto, short for Zengaku Kyoto Kaigi (All-Campus Joint Struggle League). As the struggle wore on, the Zenkyoto gradually radicalized and began to question the foundations of Japanese society. They occupied the entire university for six months before being forced out by the police. Tanaka writes:

The failures of political movements such as the Anpo and Zenkyoto movements underscored America's continuing influence on Japanese politics even after the Occupation. Young males, who grew up after the failures of these political movements, consciously or unconsciously absorbed the difficulty of dealing with the power of the United States and the trauma of defeat. (Tanaka, 46)

Osawa himself points to the Red Army Coalition incident (Rengō Akagun jiken) in 1972 as the main turning point from the ideological to the fictional age. The Red Army Coalition was a merger of several different radical Marxist groups intent on the violent overthrow of the Japanese government. The Red Army was one such group that had declared war on the Japanese government and began a series of terrorist attacks that included the hijacking of a plane and an attack on the Lod Airport in Tel Aviv that left 26 dead and 80 injured. The government cracked down on this group, arresting the majority of its members and forcing its remainder to merge with other groups and eventually go 
into hiding. This new merger of radical leftists created a secret base of operations in the Nagano mountains where they conducted military training drills. What occurred there was the purge of its own ranks: 14 members of the coalition were brutally murderedsome lynched and some butchered with knives - for being insufficiently possessed of revolutionary fervor. The police discovered their whereabouts and moved to arrest them prompting the remaining members to take hostages and barricade themselves within a mountain lodge. The ensuing day-long siege was the first live marathon television broadcast in Japan, lasting 10 hours and 40 minutes. This event led to a precipitous decline in the radical leftist politics that had characterized the era.

Of course, the decline in ideological fervor was not merely on the left, but also on the right. In a different, but related, work entitled Fukanosei no Jidai (The Age of Impossibility), Osawa identifies Mishima's failed coup d'etat as another emblem of a general ideological implosion (Osawa, 13). In of all these cases, the high visibility of these ideological failures all pointed to a certain impotence within ideology itself, and the excesses of its fiercest proponents were rendered into televised spectacles that left most people feeling that these were not inspiring acts of defiance by high-mind revolutionaries, but the excesses of degenerate sociopaths. In lieu of such ideological fervor, what remained for most people was simply to enjoy the fruits of economic prosperity.

\section{THE FICTIONAL AGE}

Osawa's fictional age spans from 1972 to 1995 , but the metaphor that perhaps best captures Osawa's definition of fiction versus ideology is without a doubt the idea of 
the "bubble." Of course, the 1980s of Japan are commonly described as "Bubble era" Japan in allusion to the meteoric rise of the economy and its staggering crash shortly thereafter. It also conveys a sense of insulation. The 1980s were a time of extreme prosperity and peace for Japan, and the metaphor of bubble conveys the sense in which ordinary Japanese were trapped within a false sense of security, comfortable as they were within the warm, hyper-modern glow of a society fully resurrected from the ravages of war. There is a fundamental ambiguity at work in what might otherwise be considered a time of optimism and faith in the status quo. Prosperity brought material enrichment, but not necessarily personal or spiritual enrichment. Osawa argues that, as previously mentioned, fiction attempts to restructure ideology apart from the world, and reflects an overwhelming disappointment with the prospects of that potential world manifesting in the real world. In short, political and revolutionary activity is abandoned, but the inclination towards ideals itself is not.

It is important to recognize that there is no hard line that divides these two. Rather, the distinction reflects a continuum of attitudes that govern the perception of reality and social activity. The closer we get to the spectrum of the continuum labeled fiction, the more alienated and unconcerned with reality, often leading to an outright rejection of the current state of reality. Furthermore, the further along the fiction spectrum we get, the more inclined we become to reject the established order outright and abandon the project of adjusting or changing it. Osawa argues that what begins to take its place is an apocalyptic rhetoric, in which the world becomes beyond salvation, and ideals totally untenable without wiping the slate clean. He defines fiction as the impulse towards 
ideology preserved and expanded in fiction (Osawa, 56). This can be construed literally in the sense that popular media such as manga and anime serve as a space for exploring and satisfying ideological impulses, but also figuratively in new forms of consumerism and the esoteric religious cosmologies of the new age cults that began to flourish during this time.

The three emblems that Osawa holds up to personify fiction are the construction of Disneyland, the development of Shibuya as Tokyo's primary sakariba in the place of Shinjuku, and the emergence of the shinjinrui as the native inhabitants of this new, "fictional" era (Osawa, 46-49). The term shinjinrui can be translated as "the new human" or the "the new breed." The term first appeared in 1985 when the Asahi Journal ran a series of interviews with young Japanese entitled Shinjinrui no Kishutachi or "standard bearers of the new breed" (Herbig). It generally refers to people that came of age during the 1970s and afterwards. The generations that grew up in the 1970s and 1980s had no experience of the hardships associated with post-war reconstruction. Instead, they grew up in a wealthy, influential, technologically advanced nation that encouraged them to style themselves as members of an affluent society. Quite unlike the youth of the 1950s and 1960s, the shinjinrui had no interest in leftist politics, and in fact, practically no political inclinations of any kind, leading them to be dubbed the shirake sedai, i.e. the reactionless generation (Herbig). ${ }^{5}$ The difference was not merely cultural, but physical. Where previous generations had endured food shortages, the new generation had enough

\footnotetext{
${ }^{5}$ While the word shirakeru can mean apathetic, it has the nuance of being unamused or bored by a situation. It also has the connotation of being spoiled.
} 
to over-indulge on a regular basis from the time they were young. Between 1965 and 1985, the average height for Japanese men increased over 7 centimeters and the average weight increased by 5 kilograms while the average height for Japanese women increased by 6 centimeters and the average weight by 1.4 kilograms. In lieu of ideological or political aspirations, this generation was more interested either in personal advancement in the corporate superstructure or in a personal agenda focusing on how they might engage in new lifestyles of their own design. If these lifestyles presented new values that posed a challenge to the authority of the previous generation, the affluence and wealth available to the shinjinrui allowed them to wriggle out from underneath the weight of these older social structures. For example, many young people during this time were empowered to move out of their family home and live alone, giving rise to yet another moniker: Dokushin Kizoku, the aristocratic singles (Herbig).

Each item under consideration here-Disneyland, Shibuya and the shinjinruireflects a certain alienation, insulation or disinterest with the ideological struggle that defined the recent past. Disneyland functions as a good metaphor here because it signifies not only the great success of Japan's rising bubble economy, but also a literal, physical sense of alienation from the world. Disneyland was intentionally built with great care so that once customers entered the establishment, they could not see beyond its borders. This was done with the idea that patrons (children especially) could fully immerse themselves in an autonomous fantasy world without the intrusion of the mundane. In this sense, Disneyland as a consumer experience bills itself entirely on being able to purchase a temporary escape from ordinary life. To bring political or explicitly ideological activity 
into Disneyland would be a transgression of its autonomy as a fantasy space. But this absolute separation between politics and leisure made manifest quite literally in a space apart from the ordinary is itself a kind of ideology. This is where the line separating ideology and fiction starts to gain definition.

However, Tokyo's urban heart itself was experiencing a kind of "Disney-fication" at the hands of real estate developers that were allowed to proceed largely unregulated by the government. What ultimately made Shibuya the new representative of Tokyo's premier entertainment district was the total conversion of the borough into a primarily consumer space:

Shibuya's success can be largely attributed to the investments of the Seibu Group. Through these investments the entire borough was developed into a trendy, "hyper-real" space - in other words a cutting-edge space overflowing with semiotic différance — adapted to consumer society.

渋谷が成功したのは、とりわけ西武系資本の投入によって、街の全体が、 消費会社に適合した、「ハイパーリアル」でオシャレなーつまり先進的な 記号的差異に満ちた一空間へと仕立てあげられたからである。要するに、 渋谷は虚構の時代に適合した盛り場だったのだ。(Osawa, 47)

We can corroborate Osawa's assertions with contemporary depictions of Japan today. Shibuya's famous crosswalk —often show to us in time-lapse with its mass of daily commuters pulsating as a rapidly shifting mass - remains a potent symbol of not only Tokyo, but Japan as an ultra-modern nation. Beyond this, Shibuya was thus transformed into a signifier of Japan's future not only to the Japanese, but also the world at large as a signifier of the future itself. 
Osawa's use of the term haipaa riaru refers to a new level of urban immersion. It is an ultra-high definition vision of the future grounded squarely in an unequivocal celebration of consumerism. He does not explain precisely what he means by this word, but his use of the term is undoubtedly drawn from Jean Baudrillard's conception of it in his work Simulation and Simulacra. In his book, Baudrillard sketches contemporary society as a massive carnival of signs that no longer contains any reference to reality. The meaning of a given sign can only ever be another sign in an endless series of other mutating signs. In this schema, signs have attained their own autonomy and have come to exert a powerful influence over our perception of reality. Using Borges' On Exactitude in Science as an allegory, he asserts that the map as a representation usurps the territory, and eventually becomes the territory itself to which a new map is created (Baudrillard, 1). A sign without reference to anything beyond a closed system of signs he calls a simulacra. In Baudrillard's view, what distinguishes modern society from postmodern society is that where modern society is focused on production by means of greater and greater levels of industrialization, postmodern society is organized around producing "simulations" by which he means television, the internet, movies, advertising, virtual reality, etc

This new media ecology is essentially an engine for creating simulacra. For example, reality shows feature at their core the unscripted interactions of their subjects, but are in fact highly staged, produced and edited so that these interactions fit into a coherent narrative structure that resembles what we might expect from drama. This new vision of "reality" is thus adopted by consumers as a new model to interpret themselves and their experiences. In Baudrillard's society of simulation, identities are constructed by 
the appropriation of such images, and models derived from the simulations determine how individuals perceive themselves and relate to other people. By extension, a hyperreal space is a space designed to intersect with and reflect this world of simulations. It draws upon the various intertwining systems of simulacra living within "simulations" to structure its aesthetic.

Disneyland is the best example of a hyper-real space because it represents an earnest attempt to make the map (the matrix of signs that constitutes Disney) a literal territory, and in this instance, the map is unequivocally prior. It is less obvious with Shibuya, but when we start to think of the fundamental motivations behind transforming this territory into a space meant to facilitate consumption of all kinds—-love hotels, nightclubs, shopping malls, department stores, entertainment centers-it is clear that this world cannot exist without the language of signs constructed over the decades within modern advertising and branding. Advertising itself is a field wholly devoted towards altering perceptions of products through the calculated merging of signs. These signs are merged into the image of the product so that it may be read in a certain manner. In this way, entirely novel devices or services are transmuted into absolute necessities, and luxury items do not merely confer status but are irrevocably conflated with specific "lifestyle" identities. Not unlike an American megamall, Shibuya is this world of advertising, marketing and branding rendered into a physical form. It is an attempt to hermetically seal an urban space within this territory of new and constantly shifting signs. Within this space, he asserts:

The real is produced from miniaturized units, from matrices, memory banks and command models - and with these it can be reproduced an indefinite number of 
times. It no longer has to be rational, since it is no longer measured against some ideal or negative instance. It is nothing more than operational. In fact, since it is no longer enveloped by an imaginary, it is no longer real at all. It is a hyperreal, the product of an irradiating synthesis of combinatory models in a hyperspace without atmosphere。(Baudrillard, 2)

The generation that evolved in, and were served by, this new hermetically sealed territory of images were the shinjinrui:

The youth cultures that most closely correspond with the fictional age are the shinjinrui in the first half of the 1980s and then the otaku in the latter half. The shinjinrui were not taken in by any ideology or concept, but rather asserted their identity through a "semiotic fooling about" that expressed itself at the level of their consumption of fashion and their interests. This was an attitude that expressed their liberation from the weight of the ideals that ruled the ideological age.

「虚構」の時代の若者風俗の上での対応物がまずは「新人類」（八○年代 前半）であり、ついで「オタク」(八十年代後半）である。新人類は特定 の理念や思想にとらわれることなく、ファッションや興味などの消費の水 準における「記号的な戯れ」によって自己を提示する若者である。これは 「理想」の時代を支配していた重い「理想」からの解放を前提した態度で あろう。(Osawa, 48)

For a diverse spectrum of youth-cultures emerging during the fictional age (1972 -1995) kigō teki na tawamure (semiotically fooling about) itself became its own source of ideals. There are countless subcultures and fashion trends spanning these decades - most arising out of the street culture of Shibuya and Harajuku — that perfectly demonstrate this "fooling about." What these plethora of subcultures tend to have in common is a devotion to a lifestyle that is primarily defined by aesthetics more than anything else. The various permutations of the kogyaru subculture provide a vivid and a particularly literal example 
of the frenzied semiotic mix and match embraced by the numerous permutations of the shinjinrui generation.

Kogyaru (high school girl) fashion began roughly in the 1990s, but its practices and aesthetics can be linked to earlier subcultural phenomena. The moniker gyaru (gal) had been in the use since the late 1970s to refer to the edgier, risqué styles of younger female generations, and in contemporary times, functions as suffix to denote subdivisions within a gyaru continuum. Originally, the kogyaru style was a riff on a school-girl aesthetic — blazers, skirts and long socks — that was modified for sexiness and mixed with brazen touches like dyed hair, exaggerated make-up, and occasionally cosmetic surgery. As time went on, kogyaru syle became more varied and extreme, spawning countless different variations. The term kogyaru came to be associated with juvenile delinquency and even prostitution, and was the target of much criticism from older generations. Critics saw these young women as narcissists living parasitically off their parents and undermining traditional values and feminine identity. In an article discussing youth fashion in the 1990s, cultural anthropologist Laura Miller employs the term mukokuseki (no nationality) to explain the cultural logic underpinning the kogyaru aesthetic. She uses this term to make the case that Japanese fashion trends are not driven by a desire to emulate specific trends abroad, but rather a desire to hybridize as many appealing signifiers as possible into a single ensemble:

The mukokuseki aesthetic of statelessness deliberately invokes images from somewhere or some historical time - Vietnamese peasant trousers, Native American fringe and beads, 1960s paisleys - yet combines or juxtaposes these with Converse running shoes or Japanese geta, baseball caps or Rastafarian knit beret...The suprahistorical and cultural amalgamation found in Japan's youth fashions are not simply evidence of American cultural imperialism. Closer 
attention reveals that, in many cases, appropriated items are intentionally "misused" or warped. For instance, some kogals playfully incorporated chintzy Hawaiian imagery, using fake plastic leis, orchids, koa seed necklaces, and Polynesian print sarongs, but not in an effort to look authentically Hawaiian. Those who adopted these accouterments were occasionally labeled "Local Gals" or "Pareo Daughters" (pareo musume)...Kogals and others play up the artificiality of their appearance. The results straddle sincerity, mockery, and kitsch, making it impossible to tell if or to what degree they are being done tongue-in-cheek. Miller (83-84)

A common feature of this aesthetic involves matching common or familiar items with unusual ones to create highly exotic, sometimes deliberately bizarre, new contexts: A kimono in a bright red, plaid print, 8-inch platform shoes and a wild swathe of hot-pink hair. These signifiers do not refer to the West or even the Edo period, they belong only to a network of signs bound up within kogyaru fashion culture. Hyper-real urban spaces such as Shibuya and Harajuku facilitate the play of signifiers as both a place to purchase clothing, but also as a space in which to flaunt them.

This shinjinrui generation that defined itself through fashion and personal taste found meaning through embracing the fruits of this new hyper-modernity. They were not expressing themselves through political views, but creating identity through conspicuous forms of consumption. In this sense, they fully inhabited the bubble of Japan. However, the shinjinrui is still a broad category, reflecting a broad range of beliefs and social activities. For Osawa, the subculture that fully embodies the main aspects of the fictional age is the otaku. The otaku has its origins in the shinjinrui generation, but evolved into something distinct:

The term otaku refers to a type of youth culture that developed out of the shinjinrui. If the shinjinrui are marked by behaviors that liberated them from the obsessions that ruled the previous era, then by contrast, the otaku are marked by a new, obsessive behaviors. An Otaku is a person, previously categorizable simply 
by interest in a specific area - animation, video games, computers, pop idols, etc. - that indulges themselves within that area with an excessive passion up to a point approaching irrationality. I define this irrational passion as the apparent loss of balance between the size of the "meaning" (which here we can think of as that area's social necessity, or like art, the value it has in itself) and the density of the "data" gathered by the otaku regarding that interest. The density of the data gathered overwhelms the meaning. For example, in most cases, such as the archetypal case of anime, story [monogatari] is merely the accumulation of fiction [kyoko]. Therefore, to the otaku, their beloved fictional world is something more important than ordinary reality.

オタクは、この新人類から分化・発展してきた若者の類型である。新人類 が、過去の時代を支配していた執着からの解放の身振りによって特徴付け られるのだとすれば、逆にオタクは、新たな拘泥の身振りによって特徽付 けられる。オタクとは、かつてだったら興味として片付けられるような一 見頊末なさまざまな領域一アニメーション、テレビゲーム、コンピュー タ、アイドル歌手等々ーに、不合理なまでに過㮃に熱狂的に耽溺する人々 である。「不合理なまで過剰」というのは、その領域の社会的な必要とか （芸術のような）それ自身として有すると考えられている価值といったよ うな「意味」の大きさと、その領域に関してオタクが集積する「情報」の 濃度との間に、バランスが失われているように見えるということ、「意 味」の大きさを「情報」の濃度が圧倒しているように見えるということ、 である。たとえばアニメーションの場合が典型であるように、多くの場 合、物語＝虚構の集合である。それゆえ、オタクにとっては、まるで、通 常の現実よりも、彼らが愛する虚構の世界の方がより重要なものになって いるように見えるのである。(Osawa, 48)

The concept of the Otaku that Osawa lays out here is extremely familiar, but he draws a greater significance out of their fervor for popular media then is commonly attributed. If the members of the Red Army Coalition gave themselves over to a total passion for the ideals enshrined in Marxist revolution, the otaku is characterized by a devotion to their niche interest. The difference here in terms of the structure and general orientation of 
these beliefs on a categorical level is that Marxist revolution seeks to change the conditions around it in service of its vision whereas the conditions that surround the otaku are largely a matter of indifference. They simply seek to immerse themselves ever deeper in their favorite television series, or a put another way, deeper within a particular cosmology of signs. The balance between imi (meaning) and jōhō (information) that he posits above signifies a growing preference for the voluptuous pleasure of the signs themselves over their content. The ideals represented in fiction gradually become insulated in the fiction itself, to the point where the ideals cannot live outside the boundaries of fiction. This, in essence, constitutes the key difference for Osawa between ideology and fiction. However, it would be a mistake to single out the otaku as some kind of aberration in the Japanese social fabric. What Osawa is trying to point out is the inclination of the otaku towards fiction is shared in the culture at large, and is perhaps only distinguishable by the degree of intensity.

\section{OTAKU AND HYPER-REALITY}

The story Osawa has laid out here amounts to the gradual death of grand narratives and people's struggle to cope with it. These narratives, were social structures that coordinated and gave meaning to actions both private and public, and provided stability for certain types of communal engagement. What the hyper-real and the shinjinrui signify is a perverse mutation of ideology; the rechanneling of activists energies into a new ideology of individualism. 
The death of the grand narrative, or perhaps the death of meaning, is a common thread that runs through the writings of many influential philosophers and scholars since the 1970s and into the present. This idea was first introduced by the French literary critic, Francois Lyotard, and has since become one of the main hallmarks of what is typically referred to as postmodern philosophy. In general, the term "grand narrative" refers to a variety of social constructs that emerged from eighteenth century Europe as a radical new means of social organization. The overall purpose of these constructs was to consolidate the feudal patchwork of Europe's various kingdoms into unified entities with a single, cohesive identity. This was the precondition for large, nation-states whose individual members identified themselves as "French" or "English" rather than local entities from a particular village or territory. Intellectually, grand narratives were expressed in the ideas of humanity and reason, revolutionary narratives such as Marxism, and economically as the primacy of production as the raison d'etre of the state. Osawa's argument is essentially the specific case of how grand narratives died in Japan. The zeitgeists-ideology and fiction — are the stages in a death process. In this sense, his argument is firmly located in the tradition of postmodern philosophy.

Viewed in this way, the emergence of shinjinrui subcultures and the otaku are simply affective responses to the death of these narratives. In his work Otaku: Japan's Database Animals, cultural critic Azuma Hiroki furnishes us with an image of the otaku as a restless survivor, struggling to keep their sanity in a postmodern world:

The reason the otaku, "no matter where they go, cart around tons of books, magazines, fanzines, and scraps stuffed into huge paper bags like hermit crabs" is that, if they do not ferry around "the shell of their selves"- namely their fantasies of group affiliation - they cannot be mentally stable...Modernity is ruled by the 
grand narrative. In contrast, in post-modernity the grand narratives break down and the cohesion of the social entirety rapidly weakens. In Japan that weakening was accelerated in 1970s when both high-speed economic growth and "the season of politics" end and when Japan experienced the Oil Shocks and the United Red Army Incident. From this vantage point, we can view the otaku's neurotic construction of "shells of themselves" out of materials from junk subcultures as a behavior pattern that arose to fill the void from the loss of grand narrative. (Azuma, 27)

Certainly this "hermit crab" image of gathering together the signifiers of their beloved fictions is not unlike the kogyaru who drapes herself in all a manner of bizarre trinkets and accessories, sometimes to the point they are literally plastered in them. Consumerism taken to its natural extreme is a kind of fiction: an ideology without interest in the world, only in signs. It is a giddy submersion into the hyper-real. The otaku is merely a clear representative of an extreme form of consumerism. This consumerism resembles ideological fervor, but applied to some niche interest. Osawa and Azuma are telling us that, whether we consume manga or not, we are all hermit crabs salvaging for our identities amidst the bones of the grand narratives. Viewed in this way, for all its glitz and glamour a hyper-real space like Shibuya is actually a spiritual abyss.

The zeitgeist of the fictional age simply points to the tendency within late capitalist societies to engender a type of consumer that has an almost religious attitude towards their hobbies, favorites TV shows, type of music, etc. The democratic, industrialized nations of the West (I include Japan provisionally here) have enabled this behavior precisely by virtue of the great wealth and highly developed infrastructure that allows us to live our lives largely insulated from hinbyōsō; starvation is non-existent, modern medicine can cure many diseases, the impact of flooding and earthquakes is significantly attenuated by technological advances, etc. This is, in turn, alienates us from 
reality as it simultaneously immerses us further within an increasingly technologized environment utterly distinct from the natural world.

Cities, of course, have always provided a certain measure of alienation from hinbyōsō. However, advanced technology as manifested in infrastructure has increasingly allowed us to purge death, disease, and violence from the urban environment in a way that was never previously possible. The hyper-real is like an analog prototype of virtual reality; a plane of existence insulated even from the harsher environs of the city itself, dedicated to consumption and mechanized gratification. This is what connects Shibuya with Disneyland and makes these hyper-real spaces distinct from the infamous Sanyo neighborhood in Tokyo or the Kamigasaki district in Osaka, where the experience of poverty is achingly visible. The alienation that the city provides makes the intrusion of the natural world or the possibility of sudden death that much more traumatic. It is for this reason that the Sarin gas attacks and the 1995 Kobe earthquake had such a profound effect on the national psyche. These two events have a special importance for Osawa, as they disrupted the hyper-real environs of the city and bring to a close the fictional age.

Alienation into the hyper-real is essentially a privilege of the modernized West, and arguably the desire to create hyper-real spaces reflects ideology in its purest form as defined by Osawa: the struggle to eliminate hinbyōsō. The ironic twist is that it undermines our relation to ideology by pushing hinbyōsō onto a nebulous periphery. However, the hyper-real never fully insulates us; we are always vulnerable to disaster, injury or sudden death that punctures our perception of the world as being safe or stable. 
The hyper-real works simply to obscure the possibility of such disasters from our awareness until it arrives as a cataclysmic event in our lives.

The highly visible failures of ideological activity on both the right and the left in Japan during the seventies - the violence of the red army, Mishima's suicide, the chaos and political impotence of the student movements and even the collapse of the Soviet Union in the distant background-led to a general collapse of the grand narratives that structured Japan's post-war society. From this perspective, Osawa's fictional age was brought about by a dual movement fueling the transition from the ideological age to the fictional age: alienation into the hyper-real and political disillusionment. Against this backdrop, the shinjinrui did not find classical ideological struggle compelling or convincing. They turned inward into fiction and the pleasures of the hyper-real as a space for new ideals. For otaku of the 1980s, they literally devoted themselves to fiction as the space where their new ideals could thrive. The hyper-real is the space in which the impulse towards fiction is emboldened and empowered. Spaces like Shibuya were built up by developers to function as a natural substrate for this passionate devotion toward the consumption of signs. As Motoko Tanaka astutely points out:

...Contemporary Japan [has been] standardized and media-ized with a meticulously well-kept distribution management system. Consumer need in Japan can be immediately and mechanically satisfied without the intervention of the Other. Objects of desire that previously could only be had with social communication, such as food and sexual release, can now be obtained both readily or with little or no communication. (Tanaka, 57)

This, of course, is not just true of Japan, but the post-industrial West as a whole. The fruits of modernity have led to systems where many of our most basic needs are met automatically, instantaneously, and even invisibly, beyond our awareness. Fundamentally, 
what the hyper-real represents is a desire for virtual reality. Shinjuku and Disneyland are like proto-types; virtual space in an analogue form. But what exactly is the desire for the virtual? Slovenian philosopher Slavoj Zizek provides an interesting account of this term:

[Virtual reality] provides reality itself divested of its substance...in the same way decaffeinated coffee smells and tastes like real coffee without being the real thing...Everything is permitted, you can enjoy everything - on the condition that it is stripped of the substance that makes it dangerous. (Zizek, 38)

This concept of the virtual as a desire for pleasure without consequence or the desire to decontaminate objects of their full being is at the core of the concepts of the hyper-real and fiction that we have explored thus far. Where the movement towards fiction reflects a desire to immerse oneself in an attractive world of signs in which ideals can survive untrammeled, so too does the hyper-real urban space reflect a desire for the urban stripped of anything that makes it unpleasant or dangerous. However, the hyper-real tends toward systems that also alienate us not only from the reality beyond the hyper-real, but also indirectly, from the Other. This leads to the weakening to communal perceptions of reality. Those hyper-real spaces that were developed during the late 1970s and 1980s functioned as a prototype for the proliferation of the virtual space of contemporary times. Virtual reality and hyper-reality still maintain their separate spheres, but the overall trends of technology point towards an active effort by both private and government sectors to integrate digital utility with physical space (the interaction between smartphone and the city is a good example; think of Uber and even dating services like tindr). The desire for the virtual as it is reflected in the hyper-real is intimately related to the accelerated growth and popularity of videogames from the late 70 's up to the present. However, if these spaces enable a certain type of behavior or certain relation to consumption that Osawa 
would characterize as a turn to fiction, they do not necessarily determine it. What Osawa's argument about otaku reveals is how the desire to immerse oneself into the hyper-real can reflect a happy hedonism, but it can also reflect a deep-seated resentment towards the world that can rapidly transform into a pathological nihilism.

\section{FICTION'S NEGATIVE INVERSION}

The main problem of the hyper-real is that while it is rich in signs and material pleasure it is impoverished in meaning. Irony, cynicism and studied indifference are common affective responses to the overall contemporary situation. Another common response is the formulation of elaborate and highly syncretic new age belief systems. New age belief systems encourage believers to totally submit themselves to a radically alternative view of the world that often appears as contrived as any work of science fiction or fantasy. In this sense, it is the most potent emblem of the fictional age. These belief systems often stress the falsity and meaninglessness of the world. As an extension of this, cults organized around new age belief systems often have at their core an apocalyptic narrative that either seeks escape from, or destruction of, the world in its current form. In his famous study on the motivations and socio-economic background of new age cult members, the sociologist Shimazono Susumu noted two key points: 1 . members were overwhelmingly from relatively affluent or middle-class backgrounds 2 . the primary reason cited for joining a cult was the falsity, illusory or meaninglessness of the world (Tanaka, 48). These two points seem to outline the core of the issue. In spite of being comfortable, well-fed with various forms of gratification easily at their fingertips, 
this alone does not seem able to fill a certain kind of void of meaning at the root of contemporary conditions.

For Osawa, the main emblem of the fictional age (1972-1995) is the Aum Shinrikyō. He argues that this group was merely the outermost extreme manifestation of the otaku. This is partially true in a literal sense. It is well known that Asahara Shoko and his adherents were avid consumers of manga and anime, and inspiration from these fictional sources was directly incorporated into the syncretic blend of Gnostic Christianity, Vedic mysticism, conspiracy theory and paranormal pseudo-science that defined their world view. One small example of this was a device known as the "Cosmo Cleaner," a large air-conditioning unit that Asahara claimed purified the air from the toxins of the outside world (Osawa, 50). The name "Cosmo Cleaner" was taken directly from the popular anime Space Battleship Yamato, whose narrative revolves around a desperate attempt by humans on the brink of extinction to repair an Earth that was irreversibly irradiated by hostile aliens. Furthermore, the cult made a point of retreating both physically and mentally further and further from the outside world. This was the Lotus Village, a commune established as a kind of Noah's ark for a new utopian age that they referred to as Shambala, a notion of paradise appropriated from Tibetan Buddhism. This seclusion from the scrutiny of the outside world was what allowed them to fully seal themselves away within a world of their devising. In their way, the Lotus Village was their attempt to create their own hyper-real space, a space where they could wrap themselves sensuously with the signifiers of their new fiction. A full exploration of all their religious practices is not possible here, but in brief, relics like the Cosmo Cleaner, 
Shoko's esoteric sermons and energy transference rituals like shakti pat, and extreme forms of religious training including shock therapy and days spent locked in a lightless room all contributed to this immersion in their own hyper-real.

Asahara Shoko, the leader of this group, entertained numerous conspiracy theories as part of their mythos. They viewed the Japanese government as a puppet of a malevolent, worldwide Jewish conspiracy (Freemasons) that essentially ran the world. They believed that the American government, under the influence of the Freemasons, had developed an earthquake machine that caused the 1995 Kobe Earthquake. In their eyes, the world as it was was irredeemably corrupt and in the clutches of malevolent forces. They even came to see their own commune, the Lotus Village, as being full of Freemason spies, which lead to the creation of a secret inner circle that was ultimately responsible for the gas attacks. After the Aum's failure to gain political office in 1990, Osawa notes that the rhetoric of Shoko within the group's internal publications became increasingly apocalyptic in tenor and hostile toward the Japanese government. There is even evidence to suggest that there were several failed gas attacks prior to 1995 (Olson, 413 - 416). In effect, the failure to be elected amounted to a rejection by the outside world of their fiction. This was an intolerable affront that prompted further esoteric revelations and more conspiracy theories in an effort to shore up their beliefs.

The Aum also mark the first point of contact between Japan's social circumstances and the Dark Souls series. In each game, there is always the presence of hostile, esoteric undead cults still operating in the ruins of the fallen kingdom. This is especially true in the third installment where evidence of a cult of undeath is highly 
visible throughout nearly the entire experience. Practitioners of this unintelligible faith represent the last scraps of organized society and they are wholly committed to your eradication the moment they see you. Just as the practices and aims of the Aum were obscure even to some of its own members, so too are the practices and aims of the undead cults of Dark Souls. Only their existence as a threat to player is clear. This recreates the fear and anxiety many felt towards the Aum as simply a threatening and esoteric entity.

Osawa argues that what makes new religions like Aum Shinrikyō distinct from older millenarian traditions like Christianity, is precisely their deliberate detachment from the struggle with hinbyōsō through withdrawal. Corroborating Shimazono's argument, he identifies the primary motive for this withdrawal as "the emptiness of life" (sei no munashisa) (Osawa, 35). He contrasts new faiths with old ones. For example, Christianity has enshrined within the Bible an apocalyptic narrative that involves a final, perfect union between the material and the divine (The Book of Revelation was actually a major source of inspiration for Shoko). However, most forms of Christianity take an active role in combatting hinbyōso through charity and other efforts. In other words, they do not reject the harshness of reality by withdrawing from it, but proactively struggle to eliminate it through whatever avenues available. This distinction makes them ideological in the classic sense. It is perhaps unsurprising that many people who struggle with poverty and sickness in their everyday life are often religious. If we look at an institution like the Catholic Church, the majority of parishioners come from the third world such as South America, Africa and even Asia where poverty levels are high. By contrast, religions that belong to the fictional age like Aum Shinrikyō explicitly reject the world and often yearn 
for the end of the world or some other form of annihilation. In our own culture, The People's Temple (Jones Town Massacre) and Heaven's Gate are two good examples of religions that are fictional in orientation rather than ideological.

Shimazono's study of the motivations to join groups like Aum Shinrikyō seems to indicate that there is a desire to fill a certain lack that emerges out of modern experience. This is at the root of the turn from ideology to fiction, an earnest desire for meaning in the face of the ambiguity, chaos and ideological vacuity of contemporary times. Fiction is like the life-line within this turbulence, but the deeper one insulates themselves within this territory, the higher the potential for pathological behavior. If the otaku happily spending his days completely obsessed with the mythos of his favorite franchise is a "positive" alienation into fiction and the hyper-real, then the doomsday cult that practices terrorism is a negative alienation that cannot tolerate the world beyond the boundaries of their fiction. The obsession of the Aum with the fiction of their own devising, and their complete withdrawal into the lotus village - their attempt at a hyper-real space of their own design — rendered them incapable of accepting anything existing in contradiction to their fiction. This is the point in which attachment to fiction can lead to a nihilistic rejection of the world. In the context of postmodernity - that is to say a world in which grand narratives cease to function - the inability for reality to sustain the ideals latent within this fiction will often lead to the conclusion that reality itself is somehow tainted.

\section{POST-FICTIONAL WORLD}


The Sarin gas attacks of 1995 demolished the illusion of stability created in the fictional age. This happened in tandem with the Kobe earthquake three months prior which left 6,000 dead, 44,000 injured, 300,000 homeless, produced ten trillion yen in damage (2.5 percent of Japan's GDP), and created widespread and severe destruction of infrastructure. Ensconced as they were in increasingly hyper-real environs, ordinary Japanese felt safe in the knowledge that their technology-driven society with its advanced city planning, well-maintained infrastructure, and efficient social systems, including the police and Self Defense Forces, could protect them from the natural disasters and social unrest of previous decades. This event shattered a certain measure of faith in the stability of their lives and the government, and had a powerful effect on the national psyche. It reintroduced into urban life the prospect of a sudden and meaningless death. In his diary, psychiatrist An Katsumasa described his feeling towards the Kobe earthquake as reality syndrome:

As I experienced the earthquake and continued to live in the disaster area...I realized that my sense of value and my way of feeling has gradually changed. Let me temporarily term it "reality syndrome." ...The overwhelming experience of the earthquake and visions of devastated landscapes deprived me of words - even though various emotions arose, I could not put them into words - I felt like such emotions would become lies if I verbalized them. I realized that reality [riaru na mono] is merciless and deprives us of words. In my case, as I am deeply caught by real events, I begin to refuse empty words and theories. I cannot stop thinking, "such empty things will be destroyed once another earthquake comes. (Tanaka, 49)

Katsumasa's comment demonstrates the overwhelming power of the real when it intrudes upon what seems to be an impermeable fictive environment. It signifies the way increasing isolation from the prospect of such devastation makes their impact all the more 
devastating. Insulation into the hyper-real can create a state of psychic fragility-the atrophy of certain coping mechanism is the source of this "reality syndrome."

Haruki Murakami gives us a similar picture of psychological disturbance with regard to the Aum cult. After the Sarin gas attacks, he recounted in Underground: The Tokyo Gas Attack and the Japanese Psyche his uncanny feelings and hatred when he first encountered Aum believers during the 1990 election campaign. These recollections are extremely insightful and help us understand the anxiety produced by these events in a concrete way so I will quote him at length here:

Day after day strange music played from big trucks with sound systems, while white-robed young men and women in over-size Asahara masks and elephants heads lined the sidewalk outside my local train station, waving and dancing some incomprehensible jig.

When I saw this election campaign, my first reaction was to look away. It was one of the last things I wanted to see. Others around me showed the same response: they simply walked by pretending not to see the cultists. I felt an unnameable dread, a disgust beyond my understanding. I didn't bother to consider very deeply where this dread came from, or why it was "one of the last things I wanted to see." I didn't think it was all that important at the time. I simply put the image out of my mind as "nothing to do with me"

Faced by the same scene, no doubt 90 percent of people would have felt and behaved the same way...Very Likely German intellectuals during the Weimar period behaved in a similar fashion when they first saw Hitler...

The Aum "phenomenon" disturbs precisely because it is not someone else's affair. It shows us a distorted image of ourselves in a manner none of us could have foreseen. The Hare Krishnas and all the other new religions can be dismissed at the outset (before they can even enter into our rational mind) as having no bearing on us. But not Aum, for some reason. Their presence- their appearance, their song — had to be actively rejected by an effort of will, and that is why they disturb us...these subconscious shadows are an "underground" that we carry around within us, and the bitter aftertaste that continues to plague us long after the Tokyo gas attack comes seeping out from below. (Murakami, 228)

Murakami's conclusion is that ordinary people have something "Aum-ish" within them that they actively repress, the "underground" of our psyches where all sorts of monstrous 
ideas and emotions live. It is precisely the way they reflect the dark murk of our own unconscious that makes the Aum itself so frightening. We do not want to identify in even the smallest way, but there exists a capacity for terrible actions in all of us. Those who are so nakedly beholden to the worst of humanity's impulses force us in a small way to recognize the darkness that dwells in the inner selves we keep hidden. What the Aum signifies is the capacity that human beings have towards self-deception and a desire forsake the burden of thinking for ourselves. Life is much a simpler when give over our agency over to another. In a later passage, Murakami expresses a sentiment that helps to link his own disgust with the Aum with Katsumasa's reality syndrome:

Common to [the Tokyo gas attacks and the Kobe earthquake] was an element of overwhelming violence: the one an inescapable natural calamity, the other an avoidable man-made disaster. A tenuous parallel perhaps, yet to those most affected the suffering was frighteningly familiar. The source and nature of the violence may have differed, but the shock in both cases was equally devastating. That was the impression I got, talking to the survivors of the gas attack.

Many of them remarked how intensely they "hated those Aum thugs," yet they found themselves deprived of any outlet for their "intense hatred." Where could they go? Where to turn? Their confusion was compounded by the fact that no one could pinpoint the sources of the violence. In this sense- having nowhere to direct their anger and hatred — the gas attack and the earthquake bear a striking formal resemblance. (237)

Both events in 1995 signaled a fundamental instability in both the social and physical realms: Ordinary people were still at the mercy of nature in spite of modern, urban infrastructure and uncanny others lurking in plain sight might suddenly release random and arbitrary death. These two sources of anxiety have created a diffuse miasma of doubt that has eroded Japan's old value structures, particularly in the eyes of recent generations. It is important to remember that members of the Aum cult themselves also felt that they were victims of an uncanny other, that the government was controlled by a cabal, the 
Kobe earthquake was manufactured and their very own organization filled with spies. It was almost as if the whole Aum cult was gripped by "reality syndrome." With this view in mind, the post-fictional world is not merely a world in which grand narratives have ceased to function, but is also populated by hostile others that are either hidden in plain view or somewhere impossibly far away.

\section{THE ANIMAL AGE}

Taking into consideration the arguments of Osawa, Tanaka and Azuma, the Postfictional age has two basic features: 1. Grand narratives (ideologies) and fiction no longer function 2. Awareness of an uncanny other-whether it be impossibly near (terrorist) or impossibly far (government/corporations - has become diffuse within contemporary consciousness. But if even fiction has ceased to function, what lays beyond it? After all, new age cults are still abundant, kogyaru of every stripe continue to adorn themselves in increasingly outlandish attire, and the otaku continue their cosplaying, convention going, anime-watching, etc. Azuma Hiroki argues that beyond fiction lies animalization.

Fiction and ideology may have fundamentally different orientations towards the world, but they both function as narratives that orient collective and individual action, even pathological action in the case of the Red Army Coalition or The Aum Shinrikyō. Animalization refers to a process where even the limited communities made possible in fiction are undermined. Azuma takes Osawa's notion of a post-fictional age and re-labels it the Animal Age. Azuma gets the name for his zeitgeist from the famed French philosopher and statesman Alexander Kojeve's conception of desire. In particular, Kojeve located the difference between animal and human on the basis that animals merely have 
appetites where human beings are driven by insatiable desires that are always aimed towards the Other (Kojeve, 1-4). This idea emerged out of a series of lectures Kojeve gave on Hegel in 1947. These lectures were attended by many who would become leading lights in the French intellectual scene in the decade following WWII. In particular, his idiosyncratic interpretation of Hegel's concept of the Lord and Bondsman dialectic (more famously known — and in fact popularized by Kojeve—as the Masterslave dialectic) would become a key idea adopted by many thinkers. The basic premise of this idea is that human beings desire recognition from the Other as autonomous, selfconscious beings. This brings individuals into conflict, and ultimately, leads to a contest of superiority. The "master" is the one that emerges victorious and renders the loser a "slave" to their will. However, the conquest of the master is a pyrrhic victory; his desire was for recognition, but in rendering the Other into a slave, he finds that the recognition given by a slave does not have value and cannot sate his original desire. Instead, he craves the recognition of a social equal. In other words, in pursuing his desire, he negated that which he sought. Other conflicts would simply bring about the same results. Furthermore, the slave is fundamentally in the same position. The main difference is that the slave seeks to alter the status quo through labor and resistance, but should they overthrow the master, the positions will change but the dilemma will remain. For Kojeve, only a society of social equals bound by mutual respect could end this cycle and bring about Hegel's so-called End of History. However, from the traditional Hegelian perspective, this cycle of desire and conflict itself was the main engine of change in society toward human freedom. Fundamentally, it is the idea that the dialectic movements 
of history, i.e. the master-slave dialectic, is not a pointless loop of violence or oppression, but an upward spiral towards a final destination. Azuma does not adopt this view. Instead, he shares Kojeve's view that the current age is an age where the fuel powering the dialectic, human desire, is missing.

There are two important points to consider here. The first is that the position favored in this binary is not master, but the slave. The slave is the agent of history, pushing society forward and developing themselves as they struggle to serve the whims and appetites of the master. The other point is that this dialectic is catalyzed and driven by a mutual desire for recognition by the other. This points to the inter-subjective nature of desire. Animals, Kojeve asserts, merely have appetites; when an animal is hungry, their appetite is aimed at an object. Consuming the object nullifies the appetite. It is a unilateral relationship, and essentially a closed circuit between subject and object. The example Kojeve uses to contrast the inter-subjective quality of desire with appetite is how a man desires a woman. When a man pursues a woman, he does not merely desire sexual gratification alone. He desires that she desire him, and if he attains her, this only gives birth to more desires (Kojeve, 8). Perhaps he wants an attractive mate so that he may flaunt her in public as a symbol of his worth and masculinity, in which case he desires that others desire what he has. As the relationship deepens, he may feel insecure and desire her jealousy. He may flirt with other women in front of her to provoke jealousy to confirm his desirability in her eyes. It is easy to see how the permutations of this could go on indefinitely. Whatever the specifics may be, certainly where romance is concerned, desire begets more desire, and insofar as this desire is linked to the others and their 
desires, it reflects Kojeve's fundamental ontological distinction between human and animal. To be sure, humans have appetites just as animals do, but our self-awareness as individuated subjects is dominated by these abstract, socially-oriented desires.

Borrowing this definition of desire, Azuma picks up from Kojeve's formulation and argues that Japan's hyper-real, consumer society has undermined this human desire and pushed the youngest generation to pursue "animal" appetites instead:

The logic of American-style consumer society has grown steadily since the $1950 \mathrm{~s}$ and has now spread throughout the world. Today's consumer society has been standardized, media-ized, and it has developed a meticulously well-kept distribution system. In it, improvements accumulate day after day so that consumer needs are satisfied immediately and mechanically, without the intervention of the other. The objects of desire that previously could not be had without social communication, such as everyday meals and sexual partners, can now be obtained very easily without all that troublesome communication through fast food or the sex industry. So it can be said that in this way our society has truly been stepping down the path of animalization for several decades.

消費者のニーズは、できるだけ他者の介在なしに、瞬間に機械的に満たす ように日々改良が積み重ねられている。従来ならば社会的なコミュニケー ションなしに得られなかった対象、たとえば毎日の食事や性的なパートナ 一も、いまではファーストフードや性産業で、きわめて簡単に、いっさい の面倒なコミュニケーションなしで手に入れることができる。そしてこの かぎりで、私たちの社会は、数十年間、確実に動物化の道を歩夕続けてき たと言える。(Azuma, 127)

If automaticity and convenience have eliminated, and continue to eliminate, the need to interact with others, then the collapse of narrative further deprives the otaku of an inclination to participate in the wider society at either a political or social level. In the most extreme cases, they are thus perfectly enabled - wrapped in a cocoon of fast food delivery and instant access to media - to withdraw entirely. A key difference between 
Osawa's otaku of the fictional age and Azuma's otaku of the animal age is that even the larger narratives that structure the multi-media iterations of a given franchise (Gundam is a meta-fictional territory supporting an ecology of games, light novels, manga, etc.) have lost their appeal. Instead, Azuma argues, otaku of the animal age are more interested in consuming data. What he means by data is that instead of consuming media in order to immerse themselves in a fictional world, they are really only interested in the surface features that constitute the form of the media. If a traditional otaku reads a Gundam manga because it represents certain ideals or merely so they can learn more about that universe, this newer breed is only truly interested in the design of the robots. Furthermore, this newer breeder is highly cognizant of the design language deployed in creating the robots. Everything from the shape of eyes, the width, length and shape of protrusions from the visor, the smoothness or blockiness of the limbs or any number of minute, visual details are categorized, named and shared on websites such as Tinami, where they are consumed, rearranged and fed into new designs that are re-posted on the internet in an endless loop of reproduction and mutation.

Even in the above example, the design language of the robots may still be grounded in expectations set by the meta-fiction. Azuma asserts that the otaku of the animal age have pushed into territory far more abstract. He takes a character known as Dejiko as an example. Dejiko is not a character from a specific anime or manga series but the mascot (or "image character") for a game and anime shop called "Gamers." This mascot became so popular that eventually anime and games were constructed around the character. Azuma argues that Dejiko, having no real substance or narrative context, is 
essentially reducible to a list of "affective features" (moe yōsō) that have simply been culled from a larger database: Cat ears, maid uniform, bells, tail, etc. Azuma argues that the popularity of the character, and others like it, point to the decline of narrative itself. Only this database of affective features is what matters.

Although Azuma does not directly condemn "animalism" as database consumption, his assessment of the motivations surrounding this type of consumption create a very nihilistic image of the otaku:

The principle motivations of otaku, if we allow ourselves to make the association, is distinct from that of the knowledgeable appraiser who makes level-headed judgements (conscious subject) or even the sexual agent that indulges in fetishism (unconscious subject), it is something far simpler and matter-of-fact that seems closer to the motivations of a drug addict. Upon encountering a certain character's design or the voice of a particular voice actor, the same image or voice continues to swirl about in the otaku's mind as if the hard-wiring in their brain had been altered, as if they were possessed. More than a few otaku have spoken passionately about this experience in these terms. This resembles drug addiction more than it does an interest.

...オタクの行動原理は、あえて連想を働かせれば、冷静な判断力に基づく 知的な鑑賞者（意識的な人間）とも、フェティシュに耽溺する性的な主体 （無意識的な人間）とも異なり、もっと単純かつ即物的に、薬物依存者の 行動原理に近いようにも思われる。あるキャラクタ・デザインやある声優 の声に出会って以来、脳の結線が変わってしまったかのように同じ絵や声 が頭のなかで回り続け、あたかも取りつれたようにだ、というのは、少な からぬオタクたちが実感を込めて語る話である。それは趣味よりも薬物依 存に似ている。(Azuma,129)

However, it is vital to understand, that Azuma, much like Osawa, does not think of otaku or database consumption as the activity of a marginalized, subculture. Rather, it is simply a particularly powerful manifestation in a plurality of affective responses to what he 
views as a post-modern condition. What binds them together is an inability to satiate oneself on traditional forms of meaning or social engagement. He continues:

Postmodern human beings cannot satiate their craving for meaning through social exchange and instead, being reduced to animalistic demands, fulfill this need on their own in their own way.

...ポストモダンの人間は「意味」への渴望を社交性を通しては満たすこと ができず、むしろ動物的な要求に還元することで独特に満たしている。 (Azuma, 141)

The overall picture that seems to emerge from his account is that the collapse of narrative, whether it be ideological or fictional, has pushed the Japanese cultural world towards "animalism"- essentially a kind of solitary media addiction.

However, on this point, Azuma's argument becomes overly reductive and begins to contradict some of his own arguments concerning the importance of second-hand markets in the production of this database culture. Azuma puts a great deal of emphasis on the idea that the collapse of narrative has shifted the site of popular media production away from a centralized system of professionals creating products to be consumed in markets. Instead, the animal age has ushered in the reign of amateurs producing fanfiction and other spin-offs that he claims are of equal validity, and in some cases, more important than the source material. There is thus a radical flattening of hierarchy in the process of production. He points to the importance of the second-hand market (conventions, dōjin groups, internet forums, cosplay, etc.) as the main arena of production (Azuma, 40). Given these elements, even if we take for granted this notion that narrative no longer matters, when we look at the activities of the culture itself, we do not see withdrawal from the Other, but new forms of community oriented around a different 
paradigm of meanings. It is hard to fully account for the nature and meaning of such activities given their newness, but they nonetheless severely complicate the notion of animality as the absence of inter-subjective desire.

Rather than reject Azuma's argument wholesale, I would like to offer a slightly more nuanced interpretation. Perhaps the true representative of Azuma's animal age is not so much the otaku but the hikikomori (social shut-in). The hikikomori is distinct from the otaku simply in the way they withdraw not only from the world, but even from those that may share their interests. On the whole, Azuma's assessment of otaku culture as affective response to the overall weakening of large-scale narratives is insightful and accurate, but it cannot function as a totalizing concept that encompasses all affective responses of contemporary times. We will bracket these concerns since Azuma and Osawa's zeitgeists offers a gateway into interpreting the Dark Souls series, and countless other works that deal in apocalyptic themes, as part of the overall tapestry of postmodern consciousness. In many ways, the apocalyptic tone of these thinkers is itself a kind reaction. Both of them paint a picture of contemporary Japan that does not afford an exit from the state of decay. The only future they point towards is a post-ideological wasteland populated with otaku carting their fanzines around the block. This prognosis is largely implicit, but both are adamant about the inability of modernity to give to people a meaningful life: otakuism is merely a symptom.

The problem of modernity from its inception has always been the problem of meaning in the absence of the transcendental narratives that structured the premodern world. This problem was initially identified by Nietzsche when he declared the death of 
God, and he even predicted this would lead to things like fascism and Soviet-style communism overrunning Europe. It is easy to see how the Aum Shinrikyō can be considered an evolution of that disturbing historical process. The problem of "God," which is to say the problem of meaning, has become a legacy inherited by successive generations and its weight continues to be felt. However, perhaps all this amounts to is nothing more than an overreaction to a disappointed promise supposedly latent in modernity. We will not tackle this issue here, but it is by analyzing artifacts of culture with this view toward history and society mind that we can begin to make, albeit in a limited manner, a general diagnosis of what is at stake in terms of the values that drive the culture forward.

What we can take away from Azuma, Osawa, Murakami, Aum Shinrikyō, hikikomori and all the rest is that they all express in their manner postmodern consciousness. It is this consciousness that animates the narratives of decay. The Kobe earthquake played a major part in catalyzing this mentality, and Sarin attacks compounded it. Of course, we cannot say that these two events are wholly responsible for the emergence of postmodern consciousness, but it cannot be debated that they brought certain social problems into stark relief. They were also shocking for everyone involved. The Dark Souls series is a potent expression of this problem in postmodern consciousness in virtual form —arguably the medium that best personifies the present—and speaks to the particularly keen feelings of disillusionment and anxiety of Japan's contemporary situation. Dark Souls communicates directly to problems of meaning within a decaying social order and dealing with feelings of fear associated with sudden death wrought by 
uncanny others and the catastrophes latent within the infrastructure of our cities. It presents a vision of a world that cannot be saved, and moreover, that the attempt to save it merely compounds the degradation. These aspects of the game cannot be overlooked when trying to make sense of its great success. Our assessment thus far of postmodern consciousness will serve as our interpretive frame as we unpack the game's systems and narrative content. 


\section{CHAPTER 2: HARD WORK AND THE MAGIC CYCLE OF PLAY}

\section{$\underline{\text { PATHS NOT TAKEN }}$}

The business of literary interpretation is fraught with ambiguity due to the simple fact that an almost unending number of readings can be extracted from a single text. This is doubly the case with video games as there exist a fundamental tension between its “gameness,” or ludic qualities, and its narrative structure. Traditional literary interpretation depends on a certain level of stability within the text in order for a "reading" to be extracted. In The Great Gatsby, there is only one "path" that the reader can take through the narrative. Wilson will always shoot Gatsby and the prose description of this narrative event will remain the same for all readers. Many interpretations are possible - perhaps we can read this as a Marxist critique of the way capitalist ideology turns the proletarian class againstd itself — but such interpretation is only valid insofar as it is derived from the canonical version of The Great Gatsby. Urtexts and differing editions of a work notwithstanding, the literary critic must always deal with the original product of F. Scott Fitzgerald if they are to extract an interpretation from the work defined as The Great Gatsby. If video games, and in particular the RPG genre which will be our sole focus here, are to be thought of as a kind of text they would seem to resemble a choose-your-own-adventure novel, where reader agency determines the course of events. From a narrative perspective, thinking in this way is helpful to the analysis of Dark Souls insofar that its narrative has a roughly linear structure. There is a beginning and several narrative choices that constitute the end, and there is a finite amount of 
narrative content in between these points which is set in place by the "author" (designers). However, even here there is a problem since games as aesthetic artifacts do not primarily consist in working one's way through a narrative, egged on by a desire to know what happens next. The experience of a game consists in play, and the form this play takes can have a loose if not altogether insubstantial connection to the narrative or the fictional world that emerges therein. Imagine, for instance, you could only proceed from chapter 9 to chapter 10 of a book only on the condition that you complete a five kilometer foot race in under six minutes. In literature, there is no connection between these activities, but in a video game, the experience of the "foot race" is of enormous importance and directly influences our interpretation of the narrative. In a game like Dark Souls, which takes roughly 40 hours to complete, the overall time spent reading, watching cinematic sequences (cutscenes) or listening to dialogue probably amounts to 30 minutes if we are being generous in our estimate. Most of the game consists of the "foot race" and it is here that we experience many problems when we try to examine the meaning that emerges from games with the tools of literary interpretation.

Most video games are difficult, demanding, and laborious even for those wellversed in the medium. For people without the requisite digital literacy and basic motorskills involved without operating various game apparatus, they are simply impossible. It is this laborious and challenging aspect of games that leads video game scholar, Espen Aarseth, to term video games as "ergodic literature" where "...non-trivial effort is required to allow the reader to traverse the text"(Aarseth, 2). The word "ergodic" is derived from the Greek terms ergon and hodos, meaning "work" and "path" respectively. 
This concept, which appeared in Aarseth's seminal work, Cybertext: Perspectives on Ergodic Literature, has become a core theoretical tool in this new field. Central to this concept is the idea that the player of a game has a degree of agency not available to the reader of a book or the viewer of a movie:

A reader, however, strongly engaged in the unfolding of a narrative, is powerless. Like a spectator at a soccer game, he may speculate, conjecture, extrapolate, even shout abuse, but he is not a player. Like a passenger on a train, he can study and interpret the shifting landscape, he may rest his eyes wherever he pleases, even release the emergency brake and step off, but he is not free to move the tracks in a different direction. He cannot have the player's pleasure of influence: "Let's see what happens when I do this." The reader's pleasure is the pleasure of the voyeur. Safe but impotent. (Aarseth, 2)

However, beyond the "pleasure of influence"—which is to say the pleasure of choosing one's own "path" through the game system — lies its negative inversion of unexplored possibilities. In another article titled "Define Real," he writes:

...players are aware of the partial nature of their experience, the numerous strategies and paths not taken, and the fact that the game may contain mysteries they will never encounter, solutions outside their reach, tactics beyond their skill level...you may never know the exact results of your choices; that is, exactly what you missed (Aarseth, 3).

In literature, there are no secret chapters of the text that only reveal themselves under certain conditions. When we read The Great Gatsby from start to finish, we are confident we have read the whole work. Of course, multiple readings reveal multiple interpretations, but we are never haunted by the anxiety that there is still a vast sea of undiscovered content. From both a formal, game-design perspective as well as a textual/cinematic one, Dark Souls is a game that promotes this sensation, sometimes in a way that is unnerving, exhausting and alienating. Grappling with this sensation is a crucial aspect of how the work operates as a system of contingencies. In his analysis of 
the first Dark Souls game, Daniel Vella identifies this anxiety as "ergodic irony" (Vella, 16) to signify the way in which our own autonomy can undermine our drive towards "completion" or "mastery" of the game.

On top of the anxiety latent within ergodic irony, there is also the problem of unstable psychological modalities that emerge out the act of play. Despite the moniker of "game," there is still significant debate within the field as to whether video games should be thought of as games at all. This is not difficult to understand when we consider that video games are often both a story and game with rules and procedures at the same time. When we step on the basketball court, we enter a specific psychological frame; all actions are understood through the fundamental objective of getting the ball in the hoop given an arbitrary set of internalized restrictions (i.e. no carrying the ball, no hitting other players, etc.)

It is in fact this frame that allows one to become a basketball player. This is what Johan Huizinga, a Dutch sociologist who was the first to seriously examine the phenomenon of play in society, refers to as "the magic circle of play"(Huizinga, 32). It is the idea that games delineate a space where only a certain psychological frame may be adopted. A basketball court is a "magic circle"; it allows basketball to happen but it can only be used as such given the psychological frame of the game basketball itself. To do otherwise would be to preclude the possibility of play. A basketball court can also be used as a space for a high school prom, at which point the "magic" of the circle lays dormant. A novel, as well, is a type of magic circle in the sense that it is created with a certain psychological frame in mind. When we read a novel, typically we suspend many 
other modes of reading so that we may appreciate the story. A literary critic, a historian and a fan of literature do not read a novel in the same way, even though they may be the same person. However, all these frames are allowed and do not undermine the basic existence of the work.

Furthermore, the act of reading a novel is not typically oriented around the accomplishment of an arbitrary objective and the "rules" of reading are not grounded in a hermetically sealed set of rational axioms. A video game will stop the narrative dead in its tracks if you cannot comprehend or negotiate the game as a system of rules and procedures. Video games, and in particular the RPG genre, demand that the player shift through multiple psychological modalities in order to participate at the most basic level. One must be ready at any moment to be a cinema-viewer, a reader, an interpreter of statistical data and an executor of complex kinesthetic tasks all within the space of a few minutes.

In this sense, the magic-circle concept begins to break down as it is clear that video games are a space where numerous circles, all demanding different psychological frames, can exist together without undermining the functioning of a video game as an interactive artifact. A better way to think about video games is that they are simulations in which games in the traditional sense are either directly incorporated or can spontaneously emerge independently of the designers' intentions. Furthermore, though video games often feature fiction as a core aspect of the experience, properly speaking, they are not identical with fiction. Games are, to borrow an expression from ludologist Jesper Juul, "Half-real": 
Video games are real in that they consist of real rules with which players actually interact, and in that winning or losing a game is a real event. However, when winning a game by slaying a dragon, the dragon is not a real dragon but a fictional one. To play a video game is therefore to interact with real rules while imagining a fictional world, and a video game is a set of rules as well as a fictional world. (Juul, 1)

However, on this issue of "real" versus "fictional" dragons there is another important point to be made. Espen Aarseth contends that the dragons found in works of fantasy like The Lord of Rings, and the dragons found in fantasy-RPG games like Everquest (Sony Online Entertainment, 1999), have profoundly different ontological qualities. This is true even when it is literally the same dragon like when we consider Smaug from the novel, The Hobbit, and Smaug from the video game adaptation of The Hobbit (Inevitable Entertainment, 2003). The difference lies precisely in the difference between fiction and simulation. In an article titled "Doors and Perceptions: Fiction vs Simulation in Games," Aarseth writes:

One dragon is clearly fictional, but the other is simulated. One is there to read about, or watch on a TV or movie screen, the other is there to be played with. One is made solely of signs, the other signs and a dynamic model, that will specify its behavior and respond to our input. It is this model behavior that makes it different from a fiction, since we can get to know the simulation much more intimately than we come to know the fiction. A fiction is rarely, if ever, personal, a simulation can become so through experience. Simulations allow us to test their limits, comprehend causalities, establish strategies, and effect changes, in ways clearly denied us by fictions, but quite like in reality. (Aarseth, 35)

However, if we think of games as simulations what exactly are they simulations of? The answer to this question is straightforward if the simulation is of some worldly activity like flying a plane or driving a car. In the video game industry itself, the word "simulator" refers to a genre of game that attempts to recreate an actual, and sometimes 
painfully mundane, experience in the world. Simulations can either be of low or high fidelity but their referent is obvious.

Games that are oriented around fiction are in essence the simulation of that fiction as a digital world. This is most evident when we think of video games in their relation to established genres in traditional fiction. The sci-fi video game Halo: Combat Evolved (Bungie, 2001) seems to draw directly from several works of science fiction and cobble them together. The giant, ring-shaped space habitat (the "halo" referred to in the title) upon which the game takes place is reminiscent of Larry Niven's Ringworld series and the "Mjolnir Powered Assault Armor" that the protagonist, Master Chief, wears appears to allude to John Steakley's book Armor, which also features a plot revolving around soldiers in powered exo-skeletons combatting alien threats. It is possible to go on and on almost indefinitely in this fashion isolating certain aspects of the Halo mythos and attempting to unearth the influences from different works of the science fiction canon. This sort of bricolage is an essential feature of genre-fiction. What is different is when these elements are reconstituted as a virtual "actuality."

Designers, unlike writers, have to answer difficult questions such as how does a plasma rifle feel and sound? How fast can it shoot? Is it able to penetrate the hull of a tank? A writer is allowed to simply rely on the reader to imagine these experiential details for themselves. In this way, a game like Halo is like a simulation of the aggregate of signifiers that constitute the genre: a simulation of the simulacra. However, video games are not defined by the fictional genres that influence there aesthetic, but by gameplay conventions. Halo's fiction may be derived from science fiction, but it is first 
and foremost a first-person shooter. ${ }^{6}$ It thus has more in common as an experience with Far Cry Primal (Ubisoft Montreal, 2016) - a "shooting" game (spears, bow and arrows, etc.) which takes place in man's primeval, caveman past - than with $X$-Com, a science fiction game that also features humans in conflict with aliens, but is a strategy game with principles more akin to board games like chess or Risk.

However, video games do not merely simulate genres as aesthetic aggregates, or even the fantasy of being a space marine fighting aliens, though they do these things quite convincingly. They also simulate patterns of human existence, or to put it another way, they simulate cultural archetypes. They simulate these archetypes almost as the logical extension of the representation of these archetypes as they are found in fiction both ancient and modern.

In his work, The Hero with a Thousand Faces, the American mythologist Joseph Campbell first introduced the idea of the "hero's journey" as a story-telling pattern that is visible across many different cultures and many different ages. He describes the basic pattern as follows:

A hero ventures forth from the world of common day into a region of supernatural wonder: fabulous forces are there encountered and a decisive victory is won: the hero comes back from this mysterious adventure with the power to bestow boons on his fellow man. (Campbell, 23)

It is the recognition of this pattern that allows us to see how Luke Skywalker in Star Wars performs almost the exact same cultural function as Odysseus in The Iliad. The genre of RPG as a whole is almost entirely structured around this pattern both in narrative

\footnotetext{
${ }^{6}$ A genre of games that involve looking down the barrel of a "gun" from a first-person perspective, aiming at targets and eliminating them.
} 
and in game-design. In these games, there is almost always a quest, a journey across many lands, a process of growth (i.e. leveling up, unlocking abilities, and obtaining powerful items) and a heroic conclusion where a kingdom, or the very universe itself, is saved. Dark Souls is no different from its RPG forebears except in one, crucial category: the heroic conclusion. Not only is the heroic aspect obscured and left deliberately ambiguous, it does not even provide a genuine conclusion in the fashion where Luke selfactualizes as a Jedi and topples the evil empire. This is a crucial aspect that makes Dark Souls distinct as a work, as it simulates the hero's journey while it simultaneously subverts the core values that structure it.

\section{PHENOMENOLOGY OF VIDEO GAMES}

If video games are a simulation of fictional genres and literary/cultural archetypes rather than a fictional representation how can their meaning be interpreted? The radical open-endedness of games, their "ergodic" quality, creates problems when trying to create a rigorous understanding of a given work. This issue is something widely debated amongst game scholars, but one solution in wide-circulation is to deploy phenomenological methods as outlined by thinkers such as Edmund Husserl and Martin Heidegger when investigating the essential features of a gameplay experience. In brief, phenomenology refers to the practice of investigating reality as it comes to us in experience, rather than deferring purely to an externalized, rational set of (largely unspoken) axioms to justify our knowledge claims. 
Fundamentally, a phenomenology of games is a "first-person" analysis that does not omit the scholar's own shifting, interpretive frameworks as they interface with the game as a material system. This does not preclude other traditional methods of literary interpretation, nor other modes of inquiry such as sociology, anthropology or history, but subsumes these modes into the psychic totality of the investigator. What this allows a critic to do is to attend to the multiple psychological modalities that emerge out of play from moment to moment relative to the concrete textual and cinematic elements that provide a unifying logic to the experience. After all, video games are not just a narrative nor an abstract set of procedures and rules. They are both at the same time. These elements are usually experienced as a totality by the player, and to look at either the narrative or the gameplay alone would be to efface something absolutely essential. It is only through a rigorous, self-reflective process that the game critic can develop a coherent argument around the types of meaning that emerge out of this radically new medium.

Previously, I mentioned Johan Huizinga's definition of a game as a “magiccircle" wherein a space is delineated that requires a certain psychological frame in order for a game to exist. Since games elicit multiple psychological modalities from moment to moment, video game theorists Dominic Arsenault and Bernard Perron took Huizinga's notion and re-fashioned the magic-circle as a "magic-cycle" (Arsenault, Perron 109). This term refers to the feedback loop between player and game system where the player proceeds by probing the system which yields new game states and elicits a different understanding of the game world that prompts the player to take further actions. In the 
Dark Souls series, the player explores the world to acquire materials, which they can use to upgrade weapons that allows them to defeat stronger enemies, which allows them to explore more of the world, which will lead them to acquire more weapons and materials and so on and so forth. In the process, they will see, read and experience things that alter their perception of their activities and stimulate new courses of action.

Arsenault and Perron's concept of the magic-cycle has become a term in widecirculation throughout games studies but game designers have been aware of the centrality of feedback cycles to their medium for a long time. As Jaime Griesmer, lead designer of Halo — an essentially canonical work in the first-person shooter genre-once famously said in an interview:

In Halo 1, there was maybe 30 seconds of fun that happened over and over and over and over again. And so, if you can get 30 seconds of fun, you can pretty much stretch that out to be an entire game. (Kietzmann, web)

This quote has become a design mantra in the commercial space due to the immense status Halo enjoys in the history of games. However, later on, Griesmer would make an important addendum to this statement in another interview several years later:

There was a whole second half of the quote that got cut out of the Vidoc [video documentary] where I talked about taking that 30 seconds of fun and playing it in different environments, with different weapons, different vehicles, against different enemies, against different combinations of enemies, sometimes against enemies that are fighting each other. No 30 -second stretch of Halo is ever repeated; the missions are constantly changing the context on you. (Kietzman)

This reveals an important aspect of the magic cycle that Arsenault and Perron are well aware of, but does not come through in the term itself. Gameplay is not so much a loop but an ever-widening spiral with narrative and ludic elements inter-weaving to create a 
constantly evolving understanding of the game world as both a fictional space and a system.

In the following chapter, I will deploy a phenomenological description of a hidden area of the game I encountered very late (after approximately 30 hours of play) in Dark Souls III. Names of characters and places will be given in both the English localization and Japanese original. These localizations are relatively faithful, but can have significant deviations from the original. This is because the localization process prioritizes the marketability and sales of a game over textual fidelity. Where there is significant difference between the original Japanese and the localization, I will offer my own translation. This will be noted in the in-text citation. I will deploy phenomenological methods in order to convey the shifting psychological modalities found within the magiccycle that is particular to the series as a whole, but condensable within any particular section of the game. Although from a narrative perspective there will be much about the description that seems opaque, there is much of this opacity that is deliberately built-in to the experience. Only when we examine the contours of the magic-cycle will we be able to properly contextualize the narrative fragments that are littered throughout this potent, but brief, encounter. The interpretation of the Dark Souls series provided here will demonstrate how narrative frames play and play infuses the narrative with personal weight. 


\section{CHAPTER 3: MAPPŌ, DEAD NARRATIVES, AND UNCANNY OTHERS}

\section{GUNDA THE JUDGE, GUNDA THE FAILED HERO}

Deep in the catacombs of Lothric's castle is a long-abandoned mausoleum with a room that seems like it was once used for worship. In the middle of the room is an enormous stone chalice with a shape reminiscent of a baptismal font. Beneath it, wearing a full set of $16^{\text {th }}$ century Maximillian style plate armor, sits a knight with legs crossed in the lotus position. Is he meditating? No, he is long dead, but one wonders if he has escaped this transitory world of delusion, desire and rebirth. Perhaps he achieved that illustrious state of pari-nirvana here within a cool and lonely corner of this forsaken world.

Gazing at his peaceful form, I cannot help but think of the humorous mitate found in ukiyo-e prints. I recall an image made by Suzuki Harunobu (1725-1770) of a courtesan sailing across the sea atop a giant leaf, swaddled in bright red robes. It is a humorous reference to Bodhidharma's arrival to Japan from India (Jenkins, 100; APPX. Fig. 1). The educated and affluent of the Edo world would have been titillated to see so eminent a sage conflated with something so ribald as a girl from the Yoshiwara. Isn't our knightresting so peacefully beneath this baptismal font in an image of sublime repose- not unlike a mitate of Siddhartha when he attained enlightenment sitting beneath the Bodhi tree? Is this a clever joke by the developer to the player? It is impossible to know, but there is no reason to linger or dwell upon unsolvable mysteries. The curiosity and 
reflection ceases as the gaming instinct takes over and the room becomes a place that must be scoured for treasure.

Towards the back of the room is a chest. Popping it open, I discover a dragonscale (there is a rush of pleasure; I now have enough scales to upgrade a special weapon), but there is something quite odd about the wall behind the chest. Its color is mismatched with its surroundings. It seems too dark, as if there were some flaw with the graphical texture applied to this one segment. There is something unmistakably awkward about it, and moreover there are messages from other players emblazoned upon the floor. I do not particularly need to read them to intuit that there is something beyond this wall. I strike my sword against it and the wall fades away—nothing but an illusion. In its place is an entrance to a cave. Taking a step toward the cave bold text flashes upon the screen: Untended Graves (muen bochi). I feel a rush of excitement. Chills run through my body and my hairs stand on end. I have discovered a secret area. With trepidation, I make my way through the narrow passage, but after a few yards, I find that I am outdoors somehow. In place of the ceiling there is an endless expanse of dark, as if the roof of the cave was hundreds of feet above me. I navigate through this narrow canyon, slaying horrific creatures as I go, their tortured bodies lurch with horrifying speed, each mutilated and gone mad.

But there is something off here that has nothing to do with the horror of these abominations. A certain creeping sense of déjà vu begins to seep into my mind. As I make my way through the canyon, a path adjoining a cliff appears. The déjà vu intensifies. There are more monsters here, and I quickly dispatch them, but as I round the 
bend a great stone gate comes into view, and that nagging feeling that had been dogging me is transformed into a revelation. I have been here before, this is the way to the Firelink Shrine (hitsugi no saishiba), the same place I started at the beginning of the game. Is this some kind dark inversion of the normal game world? Is it a part of the fictional world of the game? Are we still in a diegetic space? Or is it some kind of an easter-egg hidden by the developer within the folds of this sprawling work: a fourth-wallbreaking wink to the players just to let you know that, after all, you are just playing a game.

But the feeling this place inspires is something more like dread than an inside joke. The world above beyond this secret zone is tortured and broken as it is, but this place is darker, more fearsome, more degraded and utterly devoid of hope. It is undoubtedly a recycled area, utilizing the same digital art assets, but somehow it doesn't seem inconsistent with the world that I have experienced thus far across these games. Am I stuck in a time-loop? Another dimension? An alternate world? Beyond the arches of the stone gate, I can see the crouching form of Iudex Gundyr (hai no shinpansha gunda) within the courtyard. It is exactly like it was at the beginning of the game at the Cemetery of Ash (hai no hakaba) (APPX. Fig 2). I step with trepidation past the gate, and he lifts his massive bulk, three times the size of my avatar, to its full height. He picks up his massive halberd and rushes to confront me, leaping dozens of feet into the air ground before letting his full weight smash into the stone. I just barely manage to roll out of the 
way. The boss encounter ${ }^{7}$ has begun and his life bar appears at the bottom the screen, but the name that appears just above it is different this time. It reads: Champion Gundyr (eiyû gunda) (APPX. Fig. 3). His appearance has also changed. His eyes glow red, his movements are more ferocious and wild, the attack pattern more varied, unpredictable and un-relenting.

There is something unmistakably darker and more vicious about this encounter from the first one. It also an order of magnitude more difficult. After about a minute of running around, desperately trying to get my bearings as he hounds me throughout the courtyard, I make a fatal misread of his attack patterns and he crushes my avatar under the brutal weight of his halberd. The message "YOU DIED" appears across the screen. My avatar reincarnates at the closest bonfire, far away from the site of my grisly death. I can sense that this is going to be an ordeal. The boss encounters in the Dark Souls series are hard, and typically require eight or nine deaths before I can surmount the challenge. Their difficulty is in identifying the attack patterns of the boss, allowing a player to avoid blows and exploit openings systematically. Patience, observation, and planning is rewarded, hastiness and greed severely punished. A zen-like remove from the situation is necessary. I prepare myself mentally to die many times before I have mastered Gundyr's patterns.

I do not want to waste time defeating all the monsters that stand between Gundyr and I. It is too much of a hassle. I sprint past the horrors and abominations with shield up

\footnotetext{
${ }^{7}$ Boss encounters, or boss battles, refer to special enemies that the player must defeat in order to progress. These special enemies are not only more difficult to overcome, but they tend to have more narrative importance then the generic enemies that populate a given game world
} 
like a human battering ram, only killing the ones I cannot run past. The excitement of the mode of exploration is now gone. I am not interested in where I am or why or what it means to be here. I am completely focused on the task of defeating Gundyr. This space, which was once a place of dread and wonder is now just a space to traverse as quickly as possible. Returning to the gate, there is now a shroud of fog swirling in the entryway. This is a barrier, a sealed off area only I can pass through where no other monster may follow. It is an intimate space. The fog signifies to me that the courtyard is now delineated from the rest of the game world, and beyond it only the challenge of Gundyr awaits. When Gundyr is defeated, the fog will vanish. Stepping through the fog, the encounter begins and I am summarily eviscerated after a series of ill-timed dodges. This begins a cycle of dying, reviving and rushing my way back to the courtyard.

At first I am dispassionate amidst the unrelenting death. Each death is simply a trial, an exploratory mission to further my understanding of my opponent. Each attempt, I am able to recognize his movements a little bit better, avoid his attacks more consistently, and sneak in blows without getting punished for it. I get slightly closer to defeating him each time, but after around the twentieth death, frustration begins to set in. Every slip-up I make draws out curses and angry grunts. My frustration makes me play poorly, and my gains start reversing. At the nadir of this drudgery, a malicious player from another world invades my game on one of my trips back to Grundyr and stabs me in the back as I struggle with vicious, undead attack dogs. This causes me to lose something precious, a little man-shaped cinder (nokoribi) that is used to restore my character to its full potential after a death. The frustration mounts. 
In the end, Gundyr's attacks are too wild, too varied in direction with tempos equally too slow and too fast. I am experienced with this series, and I expect it to be difficult and relish the challenge, but I have hit a wall. I feel a small pang of wounded pride at this recognition, but I reach for my laptop and consult the internet for a strategy from wiser players to solve my problem. After watching a few videos, I have gained insight into Gundyr's attack patterns: the weapon I ought to use, the times I should wait, the times I should attack, the times I should dodge and any number of infinitesimal details that will aid me. The encounter is still difficult, and the deaths do not relent, but I can see the way forward clearly now. It is simply a matter of training my fingers and eyes to perform what my mind understands in theory. After around the fortieth attempt, I enter a mode of complete absorption in the task. It is a feeling of focus and clarity, free of abstraction. There is no clumsy separation between vision, hands and controller, just the execution of the task. The solution to this encounter is now transparent, and after a short while, Gundyr falls to his knees and collapses to the floor, his body dispersing into a cloud of cinders as he does so. A message appears across the screen: "HEIR OF FIRE DESTROYED.”

Another message pops up indicating that Gundyr's soul has been automatically added to my inventory. A profound sense of calm and relaxation falls over me as my body releases the accumulated tension of countless failures. I put the controller down and luxuriate in the sensation. Using the left joystick of the controller, I swirl the camera around my avatar and admire this digital artifact I have lavished my attention and energies. I admire the white robes that drape softly over her steel plate, and the reflection 
cast by some impossible light on the blade of the silvery katana she clutches in both hands. In this state of repose, I notice all the graves clustered together like mushroom colonies ringing the courtyard, and what appears to be a massive sarcophagus shooting out from beneath the roots of an equally massive tree. Its covering is slightly ajar. I remember this sarcophagus from the Cemetery of Ash, but I had never given it any thought. Now I wonder if this is where Gundyr arose from in the same manner that I also entered this world arising from a grave. It certainly seems his size. What is Gundyr exactly and why does he guard this passage? My curiosity piqued, I open up the menu and search my inventory for his soul. Moving the cursor over its shining, golden icon, I read the item description:

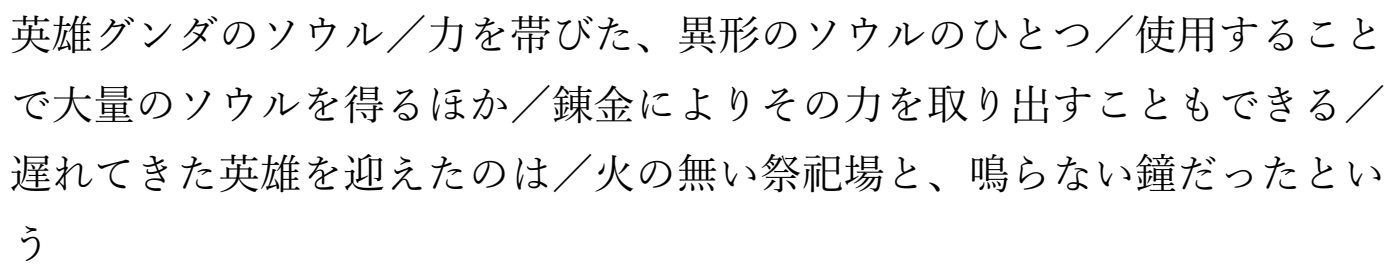

The soul of the Hero Gundyr / One of the warped souls suffused with power / By using it you can obtain a large amount of souls or / draw out its power with alchemy / A hero that came late was greeted by / a shrine without fire and a bell that would not toll. (FromSoftware, Dark Souls III; my translation)

The first part is simply a perfunctory bit of ludic information. The souls of all bosses may be transmuted into weapons and spells or consumed for a hefty portion of souls that can be used to augment my powers. But the last sentence resonates strangely with the premise upon which my journey began. I, too, was summoned by a bell into this world. In the introductory cinematic, it awoke me from my death slumber. 
When I first encountered Gundyr it was not as a champion, but as a judge. What can explain this strange transition? Is there a connection between Gundyr and I? Will I too end up as some demonic sentinel in this empty place, a failed hero rendered judge of other would-be saviors? More unresolvable questions. I make my way up the hill towards where I assume the Firelink Shrine of this dark, mirror realm will be. But unlike my shrine in the world above which is a haven full of my allies - the firekeeper who shapes

my growing powers and the glowing bonfire that dimly illuminates its stony eaves - there is nothing here but darkness and silence. In place of where the bonfire would be there is nothing but a pile of ash. Where the shrine above is the beginning point of my adventure, the shrine below is merely a dead end. It seems like the silent vestige of a failed quest, of Gundyr's quest, and maybe the ultimate meaning of my quest. I do not have a concrete way of knowing this, but I feel it to be true. Things are not really adding up in any tangible way. What is this place?

\section{FRACTURED NARRATIVE}

The phenomenological description above demonstrates the shifting psychological modes that emerge from play. These modes span from treasure hunting to awed exploration, from textual analysis to visual interpretation, from gameplay theorist to executor of motor-skill tasks, from frustration to elation and everything in between. The general flow of the game moves between a mode of embodied engagement with the concrete challenges of the world, and a sense of curiosity about the meaning of what you see and read. In general, the push and pull of the game system works to constantly keep 
the player in a state of suspense, not only in terms of the challenges of the environment, but also in the way the truth of the world is never disclosed in a coherent manner. It is extremely rich and suggestive in its presentation, but always leaves the player with more questions than it answers. To understand how this series of games operates as a totality, it is necessary to sketch out the basic game mechanics in relation to the narrative motifs that re-appear consistently, granting the gameplay a unifying logic to the overall experience.

The Dark Souls series is unique amongst other game series of the RPG genre in that it provides almost nothing to the player in terms of narrative exposition. In addition, it does not give the player a sense of certainty that the sequels bear any relationship to each other. What ties the series together and allows them to be recognized as sequels is the continuity of the game design, conceptual motifs with the limited narrative and certain affective features that are hallmarks of the series. In this sense, the series is very much aligned with Azuma's database theory as narrative in the traditional sense of the term is almost completely absent. What explicit narrative exposition that does existwhether it be cinematic "cut scenes," dialogue or scraps of text found along the wayfunctions in an abstract and mythopoeic way that can easily be ignored by players. Explicit understanding of the game world is ultimately not a necessary part of enjoying the game, however compelling it may be for some players, and therefore is reduced to a peripheral aspect of the experience.

Each game takes place in a kingdom, each with a different name that is in a postapocalyptic state of disrepair. The reason for this state of disrepair is opaque, but it 
always connected to a "curse of undeath" that prevents its inhabitants from permanently dying (they are continually reincarnated) and this eventually turns them into insane and monstrous version of their former selves. This is referred to as becoming a "hollow" (mōja), and the avatar that the player creates for themselves within the game world also suffers from this curse. This curse is signified by the dark sign (daaku ringu), a flickering ring of fire framing a black void (APPX. Fig, 4). It is implied throughout the series that only by preying on others to gather "souls" can one keep the effects of hollowing, and eventually going mad at bay. In each game, the player is tasked with "linking the flame" (hi o tsugu) which is the process by which the dead world is revived. This involves slaying five powerful entities - the progenitors and lords of the fallen kingdom during its golden age — and harvesting their souls so that they be used as a fuel source to catalyze this rekindling. Once the player has absorbed these great souls into their being, they too must sacrifice themselves as fuel for fire of the new age.

At first glance, this conceptual motif that links all three Dark Souls games together would seem to be just another riff on innumerable myths of western civilization that center around younger generations making sacrifices to revitalize tradition. However, the Dark Souls series complicates this archetypical heroic formula by casting subtle aspersions on its validity and undermining the notion of personal agency that is central to most heroic myths. The Dark Souls series shows this cycle not as a necessary process by which society survives across generations, but a desperate struggle against the natural order of things, and consequently a cycle of diminishing returns. At the end of third game, the re-kindling process has degraded to the point that the world is beyond repair. 
The player's quest amounts to nothing more than the terminal stage in a series of successive cycles of reality that have become increasingly degraded.

The concept of souls is another important conceptual motif both in terms of the narrative and gameplay. In each game world, there are only a handful of characters that have not yet turned hollow with whom you may barter with for items. The souls which you gain by killing the hollows and monsters populating the world is the currency you use to barter with these characters. These characters can become your allies in battle, but over the course of the game, many of them will eventually go hollow and attack you. From a narrative perspective, this creates an atmosphere of mistrust between those who still have their sanity, as they are likely to be that way only because they are predators. This concept also bleeds out from the narrative into the ludic. The online aspect built into the game means that at nearly any moment other players can invade your world to kill you and claim the souls on your person for their own use. This reflects the concept of the uncanny other as laid out by Murakami and Osawa. Your enemies are essentially akin to you, thus there is no one in the Dark Souls world that you can really trust in either a narrative or ludic sense.

Souls are also the primary way in which your character becomes more powerful. As you gain souls, you may spend them to augment and upgrade the power of your character and the weapons in your possession. This is crucial for exploring more dangerous parts of the world. However, as you get stronger, upgrades to your avatar become exponentially more expensive for returns that are incremental. This necessitates further exploration into the dangerous reaches of the world in search of more powerful 
souls. There is an important game mechanic bound up with the quest for souls that creates a constant sense of tension and danger as the player navigates the world. When your avatar is killed, all your accumulated souls that are still unspent are dropped at the spot where they died, but the avatar itself is resurrected at the nearest "bonfire" (kagaribi) (APPX. Fig 5). These bonfires are safe havens that mark your progress. They are spaced extremely far apart and must be "kindled" (tomosu) by the player before they can be used. The player can rest at a bonfire without fear of attack, and can even use them to travel to other bonfires they have already kindled. It is by means of bonfires that the player gains the traction to explore the world. When the player's avatar reappears at a bonfire, they have one chance to make their way back to the spot they died and reclaim their souls, which float above the ground as a green orb of swirling particles. Should the player die again before recovering these souls, they are lost forever. There is therefore always much at stake for the player in the dangerous trek between bonfires. In addition to being a safe haven, bonfires are a place for the player to replenish the health and materiel of their avatar. However, this can be a double-edged sword. When enemies are killed, they stay dead indefinitely but are resurrected whenever the player rests at a bonfire. There is thus no "free-lunch" in these broken kingdoms of the damned. All progress is hard-earned and fraught with risk.

\section{ENVIRONMENTAL STORY-TELLING}

Even though narrative is deemphasized in the Dark Souls series, it is not entirely absent. Understanding of the game-world mythos comes primarily through an interpretive 
loop fueled by rich visual information and flavor text ${ }^{8}$ that is attached to items scattered throughout the world. The primary atmosphere conveyed throughout the series is clearly post-apocalyptic, however, the third entry pushes this aesthetic much further. In the area, High Wall of Lothric (rosurikku no kōheki), the player explores a nightmarish, gothic castle in utter disrepair (Menuez; video clip). Wretches with gray skin and eyeless sockets grovel upon the ground, hands clasped in prayer (2:15) worshipping the corpses of immense dragons and human bodies that seem to undergoing a metamorphosis into spindly trees (1:18). It would appear some kind of cult has taken over here. Mostly they ignore you, but they are watched over by soldiers that scream horrifically when they see you (2:38), summoning their comrades to arms. The tone here is unambiguously postapocalyptic, but no explanations are forthcoming.

This style of story-telling has generally come to be labeled by critics and designers as environmental story-telling. At nearly any point in the game, the central question a player will ask themselves again and again in the Dark Souls series is: What happened here? Naturally, interpretations will be different, but the discovery process is an essential part of what animates the magic-cycle of play in Dark Souls. At the 2010 Game Developer's conference, designer Harvey Smith of Arkane Studios gave a lecture extolling the importance of this kind of story-telling as a unique opportunity afforded to video games as a medium:

...environmental storytelling is active. Swiss psychologist Jean Piaget showed that play, discovery and interaction are key to learning. This active approach to learning creates participation, which breeds investment. Students and players

\footnotetext{
${ }^{8}$ Flavor text typically is text on the packaging for an action figure that provides the character's background, or text attached to playing cards in popular trading card games that give the impression of a fictional background world to which the cards refer.
} 
alike bring their own experiences, so the act of interpretation gains personal meaning...the concept behind this is the Law of Closure. As humans we have an innate need to categorize and fit visual elements into a larger framework. To do so, we draw conclusions. Scott McCloud applied this concept to visual storytelling in Understanding Comics: "What's important is what happens between the panels." (Harvey)

Thus, in the phenomenological description above, the sarcophagus that is slightly ajar where we encounter Gundyr becomes linked by association through the human desire to connect semiotic dots. Harvey argues this leads to a deep sense of immersion that makes a skillfully crafted game about with spontaneously emergent meaning. Though this approach is common to many games, Dark Souls series takes this concept to an extreme, and is often considered a high-water mark for this kind of world design.

The connections that players make between text, visuals and actions in Dark Souls is stretched over significant gaps of times, and across sequels. In the second game, the player comes to a castle that was clearly the site of a battle. The corpse of giant, treelike beings - not unlike the ents from Lord of the Rings - are littered everywhere. The corpses have grown roots like trees and have completely overrun the entire castle, breaking through the heavy stone of its walls and parapets. Eventually, the player will find a lift that takes him to the lower levels of the castle, and in a large cave, they will have their first boss encounter with one of these giants, still alive despite being skewered like a pin cushion with all a manner of swords and spears. Once a boss encounter begins, a bar will appear at the bottom of the screen with the amount of "health points" that boss character has. As your character delivers blows to the boss, the health bar will go down, imparting important information to the player about their progress in the fight. Though this bar's primary function is informational, it also performs a subtle narrative function 
by naming the opponent. In this case, the boss's name appears above this health bar as The Last Giant (saigo no kyojin), Despite seeing countless corpses that resemble this boss character prior to this encounter, this is the only bit of information that sheds any light on the current circumstances. It is clear that this giant is the lost survivor of some conflict that occurred within the castle. Once this giant has been felled, its soul is automatically added to the player's inventory. The flavor-text attached to the soul reads thus:

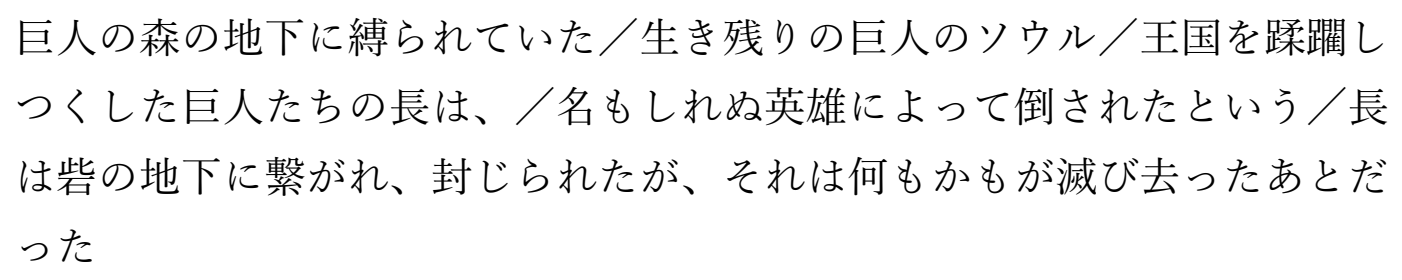

Confined beneath the forest of giants / the soul of the last giant / A chief among the giants that wreaked havoc throughout the kingdom / this giant was defeated by a nameless hero / He was bound beneath the fortress and sealed away, but / it was after nearly everything had been destroyed. (FromSoftware, Dark Souls II; my translation)

There is a lot of information here, but it raises far more questions than it answers. We know the giants were invaders, explaining the state of the castle and the numerous corpses. We know this particular giant was a leader amongst giants, and we also know that he was defeated and taken captive and this is why we find him where he is in his current state. But why did they invade in the first place? How long ago did this take place? The player is imparted with a sense of what has happened, but not much else. This constant sense of mystery is an important aspect of how the player interprets what they see, do and experience in the game world. As they continue to make their way through the game, other items with flavor text will add more information to the overall picture, but sometimes in a contradictory fashion. Every disclosure becomes a new concealment. 
The mystery of these giants is further compounded when we encounter one of their corpses toward the beginning of the third game. Is there a continuity between Lothric (third game) and Drangleic (second game), or is this merely an "easter egg," a little surprise hidden within the game as a wink to long-time fans of the series. It is impossible to know.

This style of storytelling has given rise to countless forum threads and YouTube videos devoted towards examining connections between disparate pieces of flavor text and environmental information and using this as evidence to offer up coherent explanations of the world. Some of these videos are so popular they obtain millions of views. The YouTuber VaatiVidya has made countless videos, creating theories about game lore based on evidence assembled from within the game. However, he does not stop there, but also "uncovers" narrative content by digging into the games coding and retrieving pieces of information (audio files, missing scenes, etc.) that is not normally accessible within the normal commercial release of the game. It requires special tools and knowledge of code in order to unearth such fragments, and points to the emergence of an entirely different mode of consuming fiction. VaatiVidya's many videos regularly obtain views exceeding a million, and he has managed to make a profession of his personal exegesis of the games mythos. This is only possible precisely because of the dearth of information provided by the game itself. There is very little point to theorizing about the mythos a game when the designers literally provide volumes of fictional history within the diegetic space, as is the case with the popular Western RPG, The Elder Scrolls V: Skyrim (Bethesda Softworks, 2011). Obviously, such theories are hotly contested by fans, 
and no definitive conclusion can be reached as there is simply not enough evidence built into the game.

It is interesting to note that while literally hundreds, if not thousands of videos, like this exist in the English-speaking world. This type of content is almost non-existent in the Japanese speaking regions of the web. There are thousands of videos pertaining to Dark Souls on YouTube from Japanese content creators, but they rarely, if ever, deal with unpacking the mythos from narrative fragments. It is clear that this practice is far less prevalent amongst Japanese fans of the series who seem to favor creating content that deals with analyzing the game's systems (tutorials, guides) or creating jikkyo. ${ }^{9}$ This seems to give credence to Azuma's suggestion that the newest generation of otaku is simply not interested in reconstructing a grand narrative latent in the work. It would seem that the sum of Dark Souls' richly conceived database of affective features is enough for them.

${ }^{9}$ Jikkyō: This is a genre of content, referred to as "Let's Plays" in English, found on sites like YouYube and twitch, where a gamer uploads a video of them playing game along with their unscripted commentary. The popularity of such videos is largely contingent on how entertaining the player is. 


\section{CHAPTER 4: POSTMODERN CONSCIOUSNESS, MAPPŌ CONSCIOUSNESS}

\section{$\underline{\text { MAPPŌ }}$}

As mentioned in the previous chapter, the injunction to link the flame is a central motif that drives the series; it constitutes the core objective that drives the player forward and makes progression meaningful. Linking the flame carries with it many overtones of traditional western mythology that focus on god and heroes embarking on a grand quest in order to restore the kingdom or realm to its rightful state. In many ways, the RPG genre as a whole can be thought of as a series of simulations centered around this conceit. On the surface, Dark Souls would seem no different, merely darker in tone and more abstract in presentation. However, when we examine the developmental arc of this concept across the series, it is clear that in Dark Souls linking the flame is a downward spiral leading to oblivion. Linking the flame — not unlike the old adage of "passing the torch"-represents the continuity of society and the values that structure it. It is therefore roughly analogous with the role that ideology plays in our own society. That is to say the passing on of values from one generation to another by means of grand narratives that help frame our experience of the world. The basic structure of Dark Souls casts doubt on the value of this process. It even suggests that there is something profoundly corrupt about it, and that the attempt by successive generations to preserve a sputtering flame amounts to nothing more than human vanity. It is in the metaphor presented in this notion of linking the flame that we see Osawa and Azuma's postmodern assessment of Japan's cultural landscape reflected through Buddhist metaphysics. 
The concept of mappō is an ancient eschatological concept from Buddhism's earliest days, but it never received much attention in Japan until around the Kamakura period (1185-1333). As a concept, it is theorized it developed in India during invasions by the Greeks, but did not emerge concretely until it came to China in the $6^{\text {th }}$ century:

When the thought came to China, it penetrated the popular consciousness in the period between the North-South dynasties and the establishment of the Sui dynasty. Important in this connection was the persecution of Buddhism by Chou Wu-ti in 574. (Bloom, 145)

Mappō thought, much in same manner as other types of apocalyptic thought, tended to emerge on the background of transition, strife and uncertainty. The transition from the Northern-Southern dynasty to the Sui Dynasty is a transition from a long period of political chaos to a unified Chinese empire. The Kamakura period also reflects a politically confused time as warrior clans usurped the nominally centralized imperial government in Kyoto. During those times, the concept of mappō became diffuse throughout theological discourse in the Japanese Buddhist establishment. It spawned numerous forms of Buddhism that were uniquely Japanese including the Pure Land and Nichiren sects—-popular forms of Buddhism that persist into the present. The term, which can be literally translated as "the end of the Dharma," refers to the idea that the truth contained in the Buddha's teachings will lose their relevance over time until they no longer perform any function or purpose in the world.

In total, there are three ages in Buddhism under this schema. The first 500 years after the Buddha's death are referred to as shōbo (age of the correct dharma). In this age, the teachings of the Buddha are practiced just as they ought to be and the essence of the Buddha's teachings are available to all. The next 500 years is called $z \bar{o} h \bar{o}$ (age of the 
semblance dharma), and while the teachings of the Buddha are enacted in various formal and ritualistic capacities, they have lost the essence of the dharma. The 10,000 years after $z \bar{o} h \bar{o}$ are referred to as mappō when both form and essence have deteriorated and the prospect of achieving enlightenment through the help of sages or one's efforts are completely nil. In this age, Buddhism itself will eventually be forgotten, and suffering and strife will continue on unabated.

Certainly, on a basic visual level, Dark Souls is apocalyptic in atmosphere. Furthermore, the motif of the flame that fades with each re-linking and the eschatological notion that the transmission of the dharma grows weaker, like a long game of telephone until the message is lost altogether, have strong conceptual parallels. There is even a parallel here between the three dharmic ages and Osawa's three ages of ideology, fiction and the post-fictional (animal). Osawa's argument hinges around the idea that grand narratives have become weaker and more degraded until there is nothing to sustain them at all. There are interesting historical parallels that link postmodernism and mappō thought in unexpected ways.

Although the term mappō was in wide circulation during the Kamakura period, interpretations were fairly heterogeneous. However, the origins of the term in Japanese religious life is typically associated with the emergence of a document known as the Mappō Tomyoki. This document is often attributed to the founder of the Tendai sect, Saichō (767-822), but this is hotly contested amongst experts. Many believe the document was simply a forgery by a Pure Land monk. What is not debated is the clear influence it had on the main Buddhist thinkers of the time including Hōnen, Eisai, Dōgen, 
Shinran, and Nichiren. More so than a religious document, the Mappō Tomyoki is decidedly political in tone. In it, Saichō defends the practices of monks neglecting traditional Buddhist precepts against the criticism of the government. The religious scholar, Michele Marra, unpacks the logic supporting Saichō's argument:

...The government, in its criticism, forgets that these monks are living in the Last Dharma Age (mappō) and that, therefore, they cannot apply to themselves rules which were made for and fitted to monks living in the ideal period of the true doctrine. Since in the Last Age only verbal teachings survive, while practices are non-existent and enlightenment unreachable, precepts have also disappeared and, therefore, to maintain that monks are breaking precepts is meaningless. How can something which is non-existent be broken? For the same reason, precepts cannot be kept. (Marra. 287)

However, the Mappō Tomyoki does not stop there in its rebuttal:

The Mappō Tomyoki implies that those monks who strive to keep the precepts, thus bowing to the requirements of the government, show a formal attitude towards Buddhism, forgetting the human meaning of their religion. They are therefore, compared to locusts which destroy the country... (288)

The final conclusion of the treatise is that those "nominal monks," that is to say those monks that at least act the part, should be treated with awe and reverence because they resemble the highest spiritual achievement possible given the circumstances. They should therefore be thought of as precious in the same way one might treat copper as precious in a world devoid of silver and gold. It is on this point that Azuma's tacit endorsement of "animalism" bears a certain resemblance to Saichō's argument. In an age where meaning cannot survive, what other course is there to become an otaku and wall yourself within the plush world of the affective features that only you desire. By implication, people who tie themselves to old-fashioned ideological beliefs are deluded or even dangerous. This is 
a widely held belief across the broad spectrum of philosophy that falls under the rubric of postmodernism.

Though the Mappō Tomyoki was widely influential amongst the major Buddhist thinkers in Japan, interpretation of what ought to be done given the metaphysical situation of mappō were quite diverse. However, what tends to bind these different interpretations together is a rejection of the Tendai school of Buddhism. In fact, Honen, Dogen, Eisai, Nichiren and Shinran were all trained as Tendai monks before they concluded that the institution had lost its grasp on the true dharma. This eventually led each to break with this powerful establishment to found their own traditions. The Tendai school of Buddhism had been the official sect endorsed by the Heian court since the days of Saichō. Under the auspices of powerful backers such as the Fujiwara clan and other important noble families, it flourished and grew into the dominant form of Buddhism within Japan. Its relationship with the Heian aristocracy was so intertwined, it became something tantamount to a state religion, not unlike the early Orthodox Church in relation to the Byzantine emperors. Another parallel to be drawn here is the way the Tendai sect tried to fashion their faith through a synthesis of the many heterodox Buddhist traditions encountered in China into one, master interpretation of the faith:

The first characteristic of the Japanese Tendai school is its advocacy of a comprehensive Buddhism, the ideal of a Buddhist school based on what is called the "One Great Perfect Teaching"...the idea that all the teachings of the Buddha are ultimately without contradiction and can be unified into one comprehensive and perfect system.

(Hazama, 102) 
Viewed from this perspective, traditions that embraced the idea of mappō rejected the centralized authority of the Tendai establishment. Thomas Kasulis writes about Shinran's particular response to this:

For Shinran, the authoritative institutions of the Heian worldview were no longer germane. At Enryaku-ji, the center of the Tendai establishment where Shinran had studied and practiced as a young man, they exhaustively taught all forms of knowledge, both exoteric and esoteric. Every monk had available an arsenal of practices to cut through Mara's armies of delusion and bring one face-to-face with reality as it is. The whole enterprise had had the social, economic, cultural, and political support of the Heian aristocracy. Yet, with all that insight and all that practice on the mountain, the world of Kamakura Japan in the valleys seemed to be falling apart. The government was the result of a military coup and decades of open warfare; there were widespread occurrences of disease and natural disasters; individuals turned inward for their own personal liberation but found themselves distracted and upset by internal conflicts as real and debilitating as what was happening in the external world. In that context, The Holy Path of Sages, the Tendai (and Shingon) promise of living in harmony with reality and with oneself, only exacerbated one's sense of not knowing what is really happening and what to do about it. This sense of both the world and one's self as being profoundly unintelligible and out-of-control is the essence of mappō consciousness. (Kasulis, 20)

What Kasulis refers to as mappō-consciousness is the sense that the established order is beyond salvation. There are many scholars besides Kasulis that link the emergence of mappō thought as coinciding with an unusual amount of famines, natural disasters, military conflict and political in-fighting. However, there is reason to believe the Kamakura age is not distinct from other eras of the Japanese history in terms of the actual quantity, but there was likely a qualitative difference in terms of the way religious thinkers perceived and interpreted these events. What is undeniable about the Kamakura era is that it marks a tremendous shift in Japan's cultural and political center. This was a shift away from the aristocrats in Kyoto in favor of local warrior families in Kamakura and the East in general. This shift from West to East, from centralized imperial authority 
to the local, fractured authority of clans was likely disorienting for educated elites like Shinran and Nichiren that were educated within the Tendai establishment. The disturbed political order undoubtedly posed a challenge to the narratives that grounded the legitimacy of Tendai view point and practices. Viewed in this way, mappō-consciousness is an affective response to an era where the narratives that structure society seems to be beyond salvation. A radical move away from the past becomes necessary.

There is no doubt that in our own era we live in times that are similarly turbulent and transitional. The power of the nation-state has eroded in the face of global economic systems and war has become a conflict between splinter groups operating in the margins of international politics. Corporations usurp power from democratic structures and no longer need to operate at a national level. Even Apple, an emblem of American entrepreneurship, builds its products in China, has its offices and Cupertino, and is incorporated in Ireland so as to avoid American tax rates. In our own country, President Trump's political slogan of "make America great again"10 seems to reflect a fear that things are falling apart and need to be saved. Digital technologies have altered the basic experience of human interaction in ways that are profoundly ambiguous. If we accept the general analysis of religious scholars that mappō-consciousness emerges in times of strife and transition, then the postmodernism espoused in Azuma and Osawa's work would also seem to reflect a new type of mappō-consciousness. Postmodern thought, which primarily revolves around the death of Truth and the death of narrative, comes to seem

\footnotetext{
${ }^{10}$ This is of course a rehash of Reagan's 1980 slogan, “Let's make America great again!” but it interesting to the note the shift from an enthusiastic invitation to a command.
} 
quite apocalyptic in tenor when viewed in this manner. It is a response to the growing pains of the modern age of industry and nations, giving way to the swirling ambiguities of the information age and an emerging global order.

In a similar way, the Dark Souls series belongs to this category of affective responses emerging from the mappō-consciousness of individuals living out there lives within this flux. What is remarkable about the Dark Souls series is that there is a literal dimension to its mappō-consciousness where it channels a traditional Buddhist way of apocalyptic thinking beneath a Western veneer, and within a Western medium. However, there is one important distinction between mappō and post-modern ideology: those responding to mappō during the Kamakura era were genuinely interested in pursuing a solution to the age by re-conceptualizing the transcendental values that oriented their faith. In the case of Shinran, perhaps the most postmodern-ish of the mappō thinkers, one could only escape the inevitable degradation by relinquishing one's autonomous powers (jiriki), and submitting oneself to the loving grace of Amida's vow (tariki). For Nichiren, his solution was honoring the Lotus Sutra above all others and chanting the daimoku. These are in essence spiritual solutions foregrounded against incontrovertible decline. By contrast, postmodern thought, lacking the component of faith, is reducible to a simple negation of previous value structures. This becomes its own, inverted dogma; the dogma of No-Narrative, the dogma of No-Truth. Dark Souls channels the semiotics and tradition of mappō, but it espouses a much grimmer view more in line with postmodern thought. There is no transcendent principle that counteracts the grim prognosis of mappō's metaphysical trajectory. In this way, Dark Souls is a work resplendent with the 
sensibilities of Japan's past, both modern and ancient, but rooted in a gloomy meditation on the trajectory of Japan's present.

\section{$\underline{\text { THE FIRST FLAME AS DESIRE }}$}

Using the concept of mappō consciousness and postmodernism as our interpretive framework, the core motif of linking the fire can be read both as the deterioration of societal narratives across generations and the reconfiguration of an eschatological paradigm native to Japan. The game may be overlaid with western aesthetics, but a uniquely Japanese sensibility, influenced by Buddhist metaphysics animates its aesthetics and design. The western overlay itself also parallels Japanese post-war society, and even modern Japan generally. Despite the relative autonomy with which the Japanese state was formed by Japan's native elite, there is no doubt that the central edifices that govern Japanese society — its legal, educational, political, and even cultural institutions — is a series of conceptual grafts derived from $19^{\text {th }}$ and $20^{\text {th }}$ century European society. Since its emergence in 1868 as a modern nation state, Japan has always been a remarkable feat of kumiawase, that is to say the creation of something new through the clever combination of pre-existing elements.

The Meiji state drew equally from German legal codes as it did British political and economic philosophy to structure its government. After Japan's defeat in WWII, the constitutional reform instigated by McArthur simply compounded the patchwork nature of the Japanese state. Despite the widespread popular embrace of this constitution (and its continued defense despite recent attempts to alter it), it nonetheless is an inescapably 
alien document written by a tiny coterie of Westerners. This document, which constituted the seedbed for the narrative of post-war Japan - the nation eternally at peace, eternally prosperous, and eternally in service of a progressive global order-still remains at the core of the Japanese state. But its alien-ness did not efface Japanese culture or history any more than the original Meiji constitution. Something like a constitution can only ever provide a shell or framework with which the underlying culture comes to inhabit. The core of Japanese life, and indeed the life of any person of any nation, is not defined by invisible legal codes with which ordinary people rarely have any tangible contact with, but by the layers of culture accumulated over centuries that forms the territory of everyday experience. The life of modern Japanese is strikingly similar to their western counterparts, but it is infused with sensibilities and behavior that have their roots in a deep past that has no necessary relation to democracy or economic liberalism. If the story that Azuma and Osawa lay out for us is that of Japan's crumbling societal narratives, then there is no doubt that this ruined narrative is largely characterized by those Western notions of progress, freedom, and equality inherited from Europe's political traditions. If such narratives are indeed declining, then it would make sense for this decline to be represented as a crumbling Western kingdom. It is like an image of Japan's Westerness sloughing off like so much dead skin. How better to represent this than through a vision of gothic cathedrals populated with phantoms and swarms of undead undergoing grotesque mutations?

Although the Dark Souls series has displaced narrative in favor of environmental story-telling this does not mean that it is totally devoid of traditional narrative exposition. 
However, the style of this exposition is less akin to modern works of fantasy then premodern, mytho-poetic traditions. The difference between these two can be roughly summarized as the difference between rational and intuitive principles governing storytelling in general. Largely due to the legacy of J.R.R. Tolkien's Lord of Rings trilogy, most modern works of fantasy attempt to create an entirely new world that has a comprehensive fictional history replete with fictional races, fictional languages and a set of partially transparent axioms that govern the internal reality of the work. This can become quite complicated when a work is not merely a single book, but a franchise spanning several mediums and dozens of individual works. Typically, this body of metafictional information is structured and presented in such a way that it can be interpreted via rational principles of cause and effect. This allows fans to make "rational" arguments (historical, sociological, physical, biological, etc.) about their favorite series based on the "evidence" present within a given instance of a franchise. Fans will often even criticize creators when they create new content that is not rationally justifiable given previously established axioms of the fictional universe. For example, in the Harry Potter series, spells can only be cast with wands. If in a Harry Potter spin-off a character casts a spell without a wand it would create a contradiction that is logically inconsistent with this preestablished axiom. In order to resolve this contradiction, some additional axiom would have to be established that subsumes the earlier one (i.e. this character can cast spells without the aid of wands because they have unicorn blood which grants them a deeper connection to magic). Such axioms are continually evolving to accommodate new works, 
but also to create integrity within the world-building process and avoid censure from the fans.

In contrast to this, pre-modern, mytho-poetic works make very little, if any, attempt to ground their stories in rational axioms that govern the fictional reality. Their function is symbolic or affective rather than literal, and as consequence, they would appear to be full of contradictions from a modern perspective. Why can Zeus transform into a bull or a swan? Why can the gods be wounded or killed when they are gods? In traditional myths what happens is simply what happens, there is no appeal to an underlying set of axioms. Dark Souls offers little in the way of rational principles and practically nothing in the way of comprehensive history, and in this way, its narrative style has more in common with traditional myths. It would be a stretch to call it identical, but its stubborn refusal of the rationalism of modern fantasy and their sprawling metanarratives is a key aspect of its aesthetic. The only counterpoint to this is that video games themselves are rational, mathematical systems that are gilded with narrative. There is thus always a strange conflict between the ludic and the narrative within this medium. Dark Souls skirts this problem by conceptualizing its mechanics as expressions of the problems afflicting the game world, but keeps the fine details purposely vague as to preclude formal, and rigorous understanding of the meta-fiction.

At the start of all three games is a brief cinematic that gives the player a vague, but highly suggestive framework with which to interpret the world they enter. We will look at each in turn as a sequence of aesthetic evolutions, but we will examine the first game at length, tracing the full narrative arc. This is because an understanding of the 
choices in the second and third game rely on the aesthetic principle laid out in the first. Before we begin the analysis of the intro cinematic of the first game, it is important to note that even though Dark Souls is a Japanese game, there is no Japanese voice-acting to be found in the original. In other words, the English voice-acting present within the game is not the result of localization, but an aesthetic choice by the developers to create a certain kind of atmosphere. Japanese players that do not understand English have to rely on subtitles to understand the dialogue present within the game, reinforcing the sensation of being immersed in an exotic world. It is also worth mentioning that the voice actors all affect British accents which reflects a long held-tradition within the fantasy genre across works and mediums. This is merely one more part of the overall affective database that constitutes Dark Souls Western veneer. The English audio and Japanese text are roughly equivalent, but sometimes diverge in important ways. In the following quote, I leave the English audio as is in the original:

古い時代／世界はまだわかたれず、霧に覆われ/灰色の岩と大樹と、朽ち ぬ古竜ばかりがあった／だが、いつかはじめての火がおこり/火と共に差 異がもたらされた／熱と冷たさと／生と死と／そして光と闇と／そして、 闇より生まれた幾匹かが／火に惹かれ、王のソウルを見出した／最初の死 者、ニトノイザリスの魔女と、混沌の娘たち／太陽の光の王グウィンと、 彼の騎士たち/そして誰もしらぬ小人/それらは王の力を得、古竜に戦い を挑んだ／グウィンの雷が、岩のウロコを貫き／魔女の炎は嵐となり／死 の瘴気がニトによって解き放たれた／そしてウロコのない白竜、シースの 裏切りにより／遂に古竜は敗れた。／火の時代の始まり／だが、やがて火 は消え、暗闇だけが残る/今や、火はまさに消えかけ／人の世には届か ず、夜ばかり続き／人の中に、呪われたダークリングが現れはじめていた 
In the Age of Ancients / the world was unformed, shrouded by fog / A land of gray crags, Archtrees and Everlasting Dragons / But then there was Fire and with fire came disparity / Heat and cold / life and death, and of course, light and dark / Then from the dark, They came, and found the Souls of Lords within the flame / Nito, the First of the Dead / The Witch of Izalith and her Daughters of Chaos / Gwyn, the Lord of Sunlight, and his faithful knights / And the Furtive Pygmy, so easily forgotten / With the strength of Lords, they challenged the Dragons /Gwyn's mighty bolts peeled apart their stone scales / The Witches weaved great firestorms / Nito unleashed a miasma of death and disease / And Seath the Scaleless betrayed his own, and the Dragons were no more / Thus began the Age of Fire / But soon the flames will fade and only Dark will remain / Even now there are only embers / and man sees not light, but only endless nights / And amongst the living are seen, carriers of the accursed Darksign. Yes, indeed. The Darksign brands the Undead. And in this land, the Undead are corralled and led to the north, where they are locked away, to await the end of the world... (Farz; video clip)

The musical score of this brief segment is decidedly within the vein of horror or suspense. The beginning is minimalist; moody strings hum ominously in the background while a harp adds dissonant flourishes that suffuse the imagery with mystery and foreboding. The fire is described as the origins of life and the origins of fundamental dualities of reality such as life and death (0:30). In much of Western mythology, fire or light is often used to represent the divine source of creation. This is also true of many modern works of fantasy, and thus there is a strong positive connotation attached to "light" in many cultures and mythologies. However, the affective filter cast over this metaphor presents the fire as something sinister and dangerous. Before the viewer encounters this fire, the camera takes us deep into the bowels of the earth. There the fire burns like a hellish tongue within the gaping maw of an enormous cavern. There is little about either the visuals or the music that encourages us to view the fire as a divine source of life. It would seem more like the abominable source of life. The introduction of booming timpanis and brass section as the fire comes into view suggests it is something 
both dreadful and powerful (0:50). The overall piece approaches the style of a threnody in the level of dissonance, especially with regard to the string section. The appearance of Nito is coupled with the introduction of Tuvan throat singers that drone on menacingly in the background, further compounding the sense of dread (1:15). These Tuvan singers continue throughout the introduction of the remaining three gods: The Witch of Izalith, Lord Gywn and The Furtive Pygmy (1:15-1:46). These throat singers, although a subtle addition, add a dimension of "Easter-ness" and exotic mystery to an otherwise traditional, Western orchestral score, underscoring the occult mystery that suffuses the tale.

This affective filter of dread cast over the flame is consistent with Buddhist metaphysics and metaphorical language. Within the Pali canon, the Adittapariyana Sutra, also known as The Fire Sermon, employs fire as a metaphor to represent the dukkha (suffering) that arises from desire. Tradition maintains that the Buddha gave this sermon to fire-worshiping ascetics as a way to convert them to his spiritual practice:

Bhikkhus, all is burning. And what is all that is burning? Bhikkhus, the eye is burning, visible forms are burning, visual consciousness is burning, visual impression is burning, also whatever sensation, pleasant or painful or neither painful, nor pleasant, arises on account of the visual impression, that too is burning. Burning with what? Burning with the fire of craving, with the fire of hate, with the fire of delusion; I say it is burning with birth, aging and death, with sorrows, with lamentations, with pains, with griefs, and with despairs. (Thanisarro)

In this passage, fire is conflated with the suffering brought about by our attachment to perception, but also as an aspect of fundamental binaries of reality such as life/death and pleasure/pain. This parallels fire as the origin of disparity (sai) within the Dark Souls mythos. When we see in the cinematic the roiling flame deep within the dark bowels of the earth, it does not present itself as the divine light of creation, but as the chaotic, 
primordial engine of desire. Viewed in this way, the affective filter of dread aligns closely with Buddhist metaphorical language. Furthermore, as a consequence of this fire's emergence, dreadful, pitiable, zombie-like silhouettes arise from the dark. They idiotically stagger toward this flame, holding their bodies in an awkward manner suggesting crude and unformed psyches. They have none of the dignity of the noble primitives that characterize the biblical tradition. These shambling wretches will be transmuted by the power of this flame into lofty individuals such as Lord Gwyn, but there is something tainted and odd about this heroic transformation.

The aesthetic of Lord Gwyn is clearly reminiscent of Zeus, Odin, Wotan or Indralike deities as he is a king-of-the-gods figure whose defining featuring is his dominion of light and his power to wield lightening. However, the first image we have of him is as a tired, old-man (1:34). The fire burns before him, but his eyes are milky and glazed, and his hair is wild, unkempt and seems as dry as straw, as if it has been damaged by long exposure to the heat. He seems to have none of the vitality or sagacity that can be found in traditional depictions of father-entities within mythology. Furthermore, the legion of knights that stand behind him have little in common with typical depictions of western knights. There is no semiotics of nobility, bravery or individual pageantry. Instead, these knights are faceless, uncanny entities, overly slender and tall, possessed of an insect-like aspect as their horned helmets are vaguely reminiscent of pincers. They stand in endless rows, still as statues and in perfect order beneath the eaves of a massive cavern. Those pitiable wretches transformed by the fire- which is to say transformed by their desireinto gods form a small pantheon. 
There is a father-god (Gwyn), a chaotic mother/fertility god (Witch of Izalith), and a god of the underworld (Nito). However, the presence of the "furtive pygmy" disrupts the coherence of this pantheon. He is named as one of these lords, but he is a non-participant in the struggle. His tiny, warped form crouches hungrily over the firemuch like the image of the preta (hungry ghosts) that populate Buddhist mythology (APPX. Fig. 6) - unconcerned with the machinations of these greater gods, engrossed in his little flame which flickers between his scorched palms (1:40-1:52). This image further cements the impression that the flame invites the envy of pathetic creatures even as it causes damage to its keeper. Indeed, the Witch of Izalith, despite having a much more dignified personage, has hands that also appear scorched like the pygmy (1:28). Each of the other gods is portrayed in a similar manner, each holding a flame before them as they gaze at it transfixed. This is the true origins of the age of fire, the blind desire of shambling entities that style themselves as lords.

Many classic features of Western myth and fantasy are put to work here, but they are defined by an affective filter of dread that is linked to the flame. There is no reprieve from this filter even when the age of fire is introduced. We a see a beautiful kingdom, but the light is ruddy and red, suggesting an age already in twilight. Where the music during the conflict with the dragons employs timpani, chorus and brass, signifying the energy and terror of war, this music accompanying the vision of the peaceful kingdom reverts back to the mode of suspense and foreboding during the opening segments. On the whole, the age of fire is characterized by stillness, inertia and foreboding. The overall emphasis of this intro cinematic is not on the origin of the world, but its current state of decline and 
its seemingly tainted origins. Buddhist metaphysics aside, this intro cinematic firmly establishes the apocalyptic tone of the series. The curse of the undead, represented by the dark sign (daaku ringu), is also linked with flame: a burning circle surrounding an empty abyss. This parallels the earlier presentation of the primordial flame. It too is a dim flame within a vast darkness. Through this sign, flame itself becomes associated with the curse of undeath. In Buddhist metaphysics, the burning flame of desire gives rise to dukkha which is the energy that powers the wheel of reincarnation. On this point, the dark sign creates an interesting point of contact between the gameplay semiotics and the sketch of the world mythos encountered in the cinematic.

As mentioned earlier, those afflicted with this curse cannot die. If they are killed, they merely reincarnate. Successive reincarnations lead to a character going "hollow," which means they lose their mind. In the game, this is represented visually. Those that go hollow transform into hideous, zombie-like entities not unlike the shambling seekers of the flame in the intro cinematic. This is also in-keeping with Buddhist metaphysics as escape from an endless tedium of reincarnations is the primary aim of the tradition. The highest spiritual achievement in Buddhism, the attainment of nirvana, also relies on a metaphor linked to fire. The etymology of this word literally means "to extinguish" in the sense of blowing out a candle. What mappō-consciousness layers on top of this concept is the sense that a certain spiritual degradation within human institutions has rendered people unable to extinguish the flames of desire that keep them in an endless loop of increasingly degraded reincarnations. People cannot achieve the true death that nirvana 
allows. ${ }^{11}$ It is not unlike this curse of undeath that is signified by a ring of fire that cannot be extinguished. This is what brings you back to life again and again, no matter how many times you are slain by the hollows, mutants and monsters that rule this world. Everything in this world is animated by the effects of this curse.

This roughly three-minute sequence three minutes sequence is the primary narrative frame with which the player has to interpret the first dozen or so hours of the first game in the series. More so than the narrative content itself, the overall tone and atmosphere established in this brief cinematic summarizes succinctly what the game is all about. Though none of the characters introduced in this intro will return in the second game, they are obliquely and tantalizingly referenced in the third game. This cinematic thus functions as a seedbed for the magic-cycle that will emerges as the players become engrossed in their desire to "connect the dots" between the things they see, read and do in the world. The next chapter will return to a phenomenological account of the way this opening cinematic is held in the player's mind and transformed over the course of the roughly 40 hours it takes to complete the first Dark Souls. We will not look at the first or third game in this fashion, but trace the development of the narrative and ludic motifs established in the first. This will show that the primary mission of the linking the fire is a meaningless activity that leads to increasingly degraded reincarnations of "the age of fire."

${ }^{11}$ True death is referred to as pari-nirvana as one does not die right away after attaining enlightenment. 


\section{CHAPTER 5: WHAT'S THE POINT OF BEING A HERO?}

\section{GWYN, THE LORD OF KINDLING}

Finally, after fighting my way through a fetid shanty-town of mutant cannibals, trudging through the dense muck of a poisonous swamp, and slaying a horrifying halfwitch, half-spider entity capable of vomiting lava, I have found the bell deep in the bowels of the earth in the tower of an underground cathedral. A cynical and broken knight had told me about this bell, but gave no reasons as why I might seek it. He had said it would be impossible to reach, and laughed at me, but gave no indication as to its purpose. At this point, twenty hours into the game, finding it feels almost incidental. I have simply been wandering about this dreadful wasteland, dying countless deaths, but obtaining weapons, gaining strength as I consumed powerful souls and made them my own. There is a lever by the bell and it begs to be investigated. Sure enough, it's not just for show; as I steer my avatar in front of it, a message box appears on the screen. I can pull it, and so that's exactly what I do. The very fact of its pull-ability is practically an imperative to do so. The bell rings and a cut scene begins. Somewhere far away, a faceless giant, his body a mottled grey and black as if charred by fire, hears the bell and yanks upon an enormous chain. This raises a gate to what appears to be a fortress built into the side of the cliff. I am not exactly sure where this is happening, or why, but it is clear some new part of the world has been opened up to me. I could continue past the cathedral, deeper still into forgotten depths, but I am gripped by an urge to return to the 
surface, to Firelink Shrine (hitugi no saishiba), the one place of refuge in this broken world.

Upon my return, I notice something has changed. There is a strange clacking sound resonating throughout the stony walls of the shrine. Following the sound, I make my way to the crumbling, chapel-like structure past the bonfire. There I find that an enormous serpent-like entity has emerged from the depths. Where once there was a floor of stone in the chapel, now there is an abyss and the serpent sticks his head up from this inky void, the rest of his body extending somewhere deep below. He is all black, with huge, bulging, orange eyes that have serpentine slits for pupils and strange sacs of flesh that droop from his upper lip in a manner reminiscent of a moustache. He has a human nose, aquiline in shape, and enormous teeth, block-like, jutting out from blood-red gums that he clamps together compulsively - the source of the clacking sound. On this point, he almost resembles a horse. He is truly bizarre to behold, and though he appears monstrous, he is not hostile. When I approach this creature, an option to speak appears. I Press $\mathrm{X}$ on the control pad to initiate this interaction, and he speaks in the voice of an old, ${ }^{12}$ wizened sage not at all in-keeping with his appearance:

おお、お主か／目覚ましの鐘を鳴らしたのは／わしは世界の蛇、王の探索 者フラムト／大王グウィンの親友じや／目覚しの鐘を鳴らした、不死人の 勇者よ／お主に、不死の使命を伝えたい／よいかな？

Ahh, hello. Was it you who rang the Bell of Awakening? I am the Primordial Serpent, Kingseeker Frampt, close friend of the Great Lord Gwyn. Chosen

\footnotetext{
${ }^{12}$ Japanese subtitles appear with the voice acting. The Japanese version of the game has no Japanese voice acting. It is all English in the original. Native Japanese speakers can only understand what is being said through the subtitles. This too is part of the aesthetic, adding to the overall alien feeling of the Dark Souls world from a Japanese perspective.
} 
Undead, who has rung the Bell of Awakening. I wish to elucidate your fate. Do you seek such enlightenment? (Mizu8823 5:50-6:53; video clip)

My head spins a bit. The purpose of ringing the bells was to meet this bizarre snake? Am I really supposed to believe he is friends with that guy I saw in the intro cinematic? Were the bells some kind of test? Such questions notwithstanding, this has been the first, concrete narrative development in the game in a long while. I am curious and have no reason to ignore him. I accept:

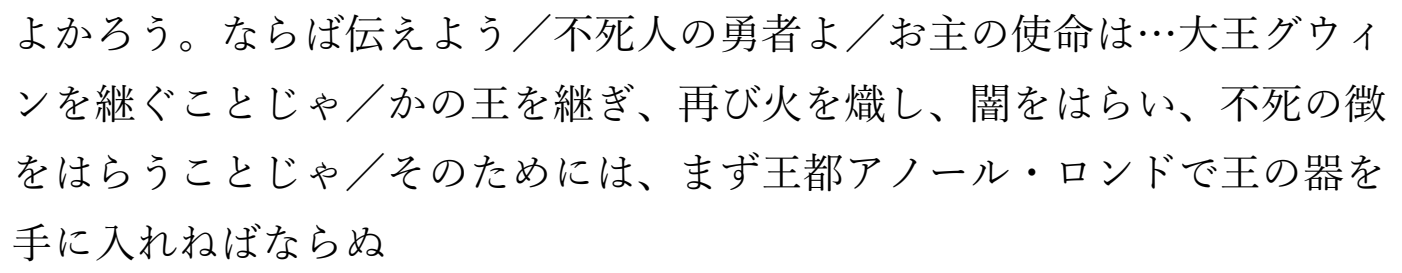

Very well. Then I am pleased to share. Chosen Undead. Your fate is... to succeed the Great Lord Gwyn. So that you may link the Fire, cast away the Dark, and undo the curse of the Undead. To this end, you must visit Anor Londo, and acquire the Lordvessel. (6:53-7:24)

This is the first direct injunction I have experienced to execute a specific task for a specific purpose. There is no real reason to refuse, and in a certain sense, no way to refuse. I can could go my own way and continue to explore the world, but at a certain point I know I will run out of places to explore. This is game, after all, it is finite. As long as I have the will to play the game- which fundamentally means exploring more of the world, gathering more items and growing in strength from the souls you consume- - then eventually I will find my way to this vessel he seeks. In the absence of anything else to do, what choice is there really?

Frampt establishes a narrative of succession and redemption from the plagues of this world, but this narrative, tentative to begin with, is soon thrown into question. After 
yet more grueling trials that take me to distant areas of the game world, I obtain this vessel, which has the shape of an enormous chalice. I bring it before the serpent again and he takes me to a chamber deep beneath the earth. He calls it the Firelink Chamber (hitsugi no saidan) and he informs me that it exists for the successor to Lord Gwyn. The chamber is simply a platform that sits before a massive set of stone doors. He instructs me to put the vessel before the doors and thereupon he informs me of my duty as "Lord Successor." He tells me that I must fill the lord vessel with great souls equal in power to the soul of Lord Gwyn. He enumerates them: Gravelord Nito, the Witch of Izalith, the Four Kings of New Londo, who inherited shards of Gwyn's soul, and Seath the Scaleless. With the exception the Four Kings, each of these "lords" was named as one of the heroes and progenitors of the age of fire - that golden age before the undead curse. I get the feeling that if I fill the vessel with these souls, the door will open. I do as he bids and I slay Nito, the Witch of Izalith and Seath. They reveal nothing to me. When I encounter them, they merely attack me on sight. Eventually, after slaying and obtaining the soul of the Four Kings in New Londo, another serpent appears exactly like Frampt with exactly the same voice and offers a counterproposal:

‥ようこそ、不死の勇者よ/我は、世界の蛇、闇撫でのカアス/貴公ら人 を導き、真実を伝える者だ/では、我は隠さず真実を語ろう／かつて火の はじまり、貴公ら人の先祖は／古い王たちの後に、四つ目のソウルを見出 した／闇のソウルだ／貴公らの人の先祖は、闇のソウルを得て、火の後を 待った／やがて火は消え、闇ばかりが残る／さすれば、貴公ら人、闇の時 代だ／‥だが／王グウィンは、闇を恐れた／火の終わりを恐れ、闇の者た る人を恐れ／人の間から生まれるであろう、闇の王を恐れ／世界の理を恐 れた/だから奴は、火を継ぎ、自らの息子たちに、火を率い、縛らせた／ 
貴公ら人が、すべて忘れ、呆け、闇の王が生まれぬように／‥我は世界の 蛇／正しい時代を、王を探すもの／だがもう一人の蛇、フラムトは、理を 忘れ、王グウィンの友に值した／よいか、不死の勇者よ／我カアスが、貴 公に、正しい使命を伝えよう／理に返して火を継ぎ、今や消えかけの王グ ウィンを殺し／そして、四人目の王となり、闇の時代をもたらすのだ

The truth I shall share without sentiment / After the advent of fire, the ancient lords found the three souls / But your progenitor found a fourth, unique soul / The Dark Soul / Your ancestor claimed the Dark Soul and waited for Fire to subside / And soon, the flames did fade, and only Dark remained / Thus began the age of men, the Age of Dark / However...Lord Gwyn trembled at the Dark / Clinging to his Age of Fire, and in dire fear of humans / and the Dark Lord who would one day be born amongst them / Lord Gwyn resisted the course of nature / By sacrificing himself to link the fire, and commanding his children to shepherd the humans / Gwyn has blurred your past, to prevent the birth of the Dark Lord / I am the primordial serpent / I seek to right the wrongs of the past to discover our true Lord / But the other serpent, Frampt, lost his sense, and befriended Lord Gwyn / Undead warrior, we stand at the crossroad / Only I know the truth about your fate / You must destroy the fading Lord Gwyn, who has coddled Fire and resisted nature / and become the Fourth Lord, so that you may usher in the Age of Dark! (13222F 1:43-3:58; video clip)

The loose sketch provided by Kaath of the historical and metaphysical underpinning of this world is far from illuminating. The age of man is the age of dark? When he says my ancestor does he mean the furtive pygmy from the opening cinematic? Was the pygmy "human" where the others were not? What even is the "dark soul"? These two quest givers, Fraampt and Kaath, are bizarre and sinister in their appearance and seem to be operating with motives that are completely opaque. Surely re-linking the flame-as KingSeeker Frampt wishes it — to usher in another age of fire free of undead would be a good thing. From the general conventions of the fantasy genre, the age of dark seems like something to be avoided. Surely anyone advocating an age of dark would have to be a "bad guy," but I understand so little about this world or about what has happened and 
what's currently going on. Isn't there a possibility that what Kaath says is true? That Gwyn, by clinging to the flame, has refused the natural cycle of the world and brought about a calamity? The truth of his statement is ultimately unverifiable within the context of the game. Regardless of which serpent I believe, the actual path of my quest seems to remain unaltered. At this point, it is simply a matter of my personal interpretation. I have filled the lord vessel with the requisite souls and I intend to open the doors to the Firelink Chamber regardless. This is simply the logic of play. It is also the logic of exploration. I simply have to know what will happen once I perform these tasks. I want to see what the game will reveal to me.

I return to the Firelink Chamber, release the last great soul into the lord vessel, and the heavy stone doors open before me, revealing a pure, white void, with an inky splotch in the middle (Entropy622 0:14; video clip). It would seem to be a passage. Walking through the white void towards the black spot, ghostly, white knights march in front of me and fade away (00:51). Are they some after-image of some past event? The void gives way to a tortured vision of a massive tower looming up in the dull and sicklyyellow sky. I cannot tell whether it is supposed to be a morning light or a fading light. It feels stuck, like I've entered into limbo. As I step between some charred pillars, the game informs me that I have entered "The Kiln of the First Flame" (saisho no hi no ro) (0:52). The floor is completely covered in grey ash, like walking through sand dunes. Was there some kind of explosion?

After fighting my way past knights in black armor (is it black because it's charred like everything else?) I confront Lord Gwyn within a chamber full of ash and a flickering 
bonfire in the center (3:52). However, when I confront him there is something wrong with him. In the opening cinematic he seems an archetypical portrayal of the father-god, but now he appears an abomination. He has gone hollow. Brandishing a flaming sword, his eyes are dark sockets and his flesh is scorched black like charcoal (APPX. Fig. 7). He has been here all along, tending the last burning ember of the world, clinging to the vestiges of the age of fire. However, it has reduced him to a mindless monster. His title has changed as well. When I step into the room and his life bar appears at the bottom of the screen, signifying another boss encounter, his name appears as Lord of Cinder (takigi nо ou). It seem his illustrious status as sun-god has been reduced to little more than a burning ember. What is the meaning of takigi here? Am I to read this as kindling? Is this what King-Seeker Frampt meant by succeeding Gwyn? I have to kill this king and succeed his title as a lord of kindling? Am I to turn myself into kindling that will feed the fire of this broken world? The meaning of who this king is, what he intended and what I am doing is extremely unclear.

What is clear, however, is a sense of tragedy. Where music for all the other twenty-five boss encounters was generally bombastic, dark and energetic, signifying the gravity, horror and thrill of the challenge, this music is lonely and sad. A lone piano plays a melancholy tune in a minor key as I struggle with the mad husk of this formerly great lord. The affect is oddly moving but also mysterious. The music seems to suggest that this conflict, being unavoidable, is tragic. But how and why would this be the case? Aren't I here to dispel the darkness and revive the age of fire? It seems to hint at the pathetic fate of all that would style themselves lord and protectors of the realm. 
After I slay Lord Gwyn, you move to the middle of the kiln where the bonfire is located. As you approach, a message box appears, allowing you press $\mathrm{X}$ on the controller to instigate an action in the world. But instead of the usual message that appears when I approach an unkindled bonfire (kagaribi o tomosu) a new option appears: hi o tsugu. At this point, I may link the flame, whereupon another cut scene begins (5:53). My avatar reaches its hand into the fire and the flames slowly spread across their body, consuming them and spreading throughout the kiln before exploding into a massive conflagration. A harp begins playing, and solitary voice of a woman begins singing and the credits roll (6:50). Presumably, this means a new age of fire has begun, but there is no exposition or further images after this point. The music that plays does not suggest or confirm anything like a triumph, but rather more sadness and mystery, as if the whole 40 hour ordeal of the game was just the enactment of a myth from long ago.

There is another option afforded to the player once they have defeated Gwyn. It is in no way obvious that it is even a possibility, but I learned about it by chance from watching videos of other players. Should the player wander from the kiln and the return to the Firelink Chamber, another cut scene will start where Frampt and Kaath appear with numerous other serpents and declare the player's avatar the new lord of the Dark (clubfc; video clip). Were they in cahoots from the start? If that was the case, why? Why would one serpent urge me towards linking the fire and while the other tries to dissuade me if in the end they both bow before the player avatar together? No answers are forthcoming, and the significance of either choice is deeply ambiguous. To link the fire is to stay true to the identity of the archetypical hero that most RPGs attempt to simulate. However, the 
lack of answers, atmosphere and ambiguous motivations of the serpentine quest-givers work against the sensation that I have saved the kingdom. If anything, it feels as though I have been manipulated into making myself a sacrificial lamb, a lord of kindling.

The motif of linking the fire will eventually be revealed as less than heroic in the following two games, but this cannot be discerned in a concrete way from the first game alone. It is merely suggested through the semiotics of the game world and felt through the act of play. The main idea to be gleaned is that Gwyn clung to the fire of life, refusing to let it fade, and he devolved into a mindless, undying monstrosity. In the metaphorical language of Buddhism, one must relinquish the burning flame of desire to escape the suffering of endless reincarnation. To live unending is to burn and burn and burn within the cycle of samsara.

\section{THIS BURNING EMBER CALLED "SELF"}

We will not examine the second game in depth, but it is worth examining the evolution of the "link the fire" motif in brief. All the other conceptual motifs that define the first game are here as well: there is an undead curse, a dark sign that signifies it, the bonfires, an injunction to obtain powerful souls, link the fire and succeed a king long since reduced to a husk, but that is all. This is a new kingdom with new impenetrable mysteries. It is worth mentioning that in this game, the player must link the fire by sitting on a throne known as the "Throne of Desire" (katsubo no gyokuza) that is housed in what is unmistakably a giant kiln, another oblique connection to the first game. This further direct connection between linking the flame and sitting on the throne of desire further concretizes the relationship between flame as a Buddhist metaphor for the desire that 
calls forth dukkha and powers the cycle of samsara. It also establishes a relationship between desire as being represented by flame, and thus points towards the way desire animates life. Unlike the first game, the player does not have a choice as to whether they sit the throne or not. Once the final boss is defeated, a voiceover will begin as the character's avatar sits upon the throne and the doors of the kiln seal the character's avatar in for good:

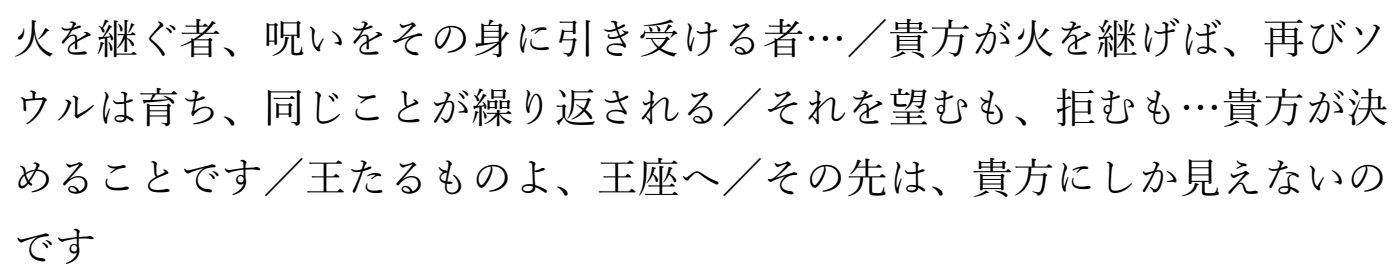

You who link the fire you / who bear the curse / once the fire is linked souls will flourish anew and all of this will play out again / It is your choice to embrace or renounce this / Great sovereign take your throne / What lies ahead only you can see. (PikaRay; video clip)

By the end of the second game, we don't have any sense if the events of the first game are even connected to its sequel, but the narrator's exposition clearly establishes "linking the fire" as simply part of a cycle. It also worth noting that creative control of the game was transferred from Hidetaka Miyazaki, lead designer at FromSoftware, to a younger subordinate, Tomohiro Shibuya for the sequel. It is thus unsurprising that there would be a number of interesting shifts in the tone and style of the game. This difference is most obvious in the third game, as directorial control was given back to Miyazaki and a much more tangible connection with the first game is clearly visible. In any case, during an interview with Famitsu, a prominent gaming publication in Japan, Shibuya stated that the second game does in fact have a connection to the first but not quite in its narrative: 
"I can't completely answer this question, but the two settings are connected, yes," he said. "However, I wouldn't say there's a direct connection as far as story is concerned. The game is set in a different part of the same planet- to put it another way, if the first game was set in the North Pole, this one would be in the South Pole; that sort of contrast. 'Time' is one of the central keywords we're keeping in mind as we create this. I can't give concrete details about this yet, so hopefully you'll be able to use your imagination for now." (Kevingifford)

Shibuya's emphasis on time is echoed within the game by the character of Straid of

Olaphis, a wandering sorcerer who aids you by selling you spells:

$$
\begin{aligned}
& \text { この地には、かの国以前にも/多くの国が存在しておったらしい／国は栄 } \\
& \text { え、しかしいずれ衰えていく／あたかも火の燃えあがり、消えるが如く／ } \\
& \text { 繰り返し繰り返し／しかしのオ、消えかけた火はやがて蘇るのよ／そして } \\
& \text { 再び国が栄える、その姿を変えながら全ては呪いよ!！ヒェヒェヒェ!／ } \\
& \text { オヌシの如き呪われ人こそが、火を引き受けるのよヒェヒェヒェ… }
\end{aligned}
$$

Many kingdoms rose and fell on this tract of earth; mine was by no means the first. Anything that has a beginning also has an end. No flame, however brilliant, does not one day splutter and fade. But then, from the ashes, the flame reignites, and a new kingdom is born, sporting a new face. It is all a curse! Heh heh heh! And it is your cursed flesh that will inherit the flame. Heh heh... (FromSoftware, Dark Souls II)

This theme of long cycles of time, of kingdoms rising and falling in different incarnations, aligns with a Buddhist apocalyptic aesthetic over a Christian one. In the Christian apocalypse, Jesus returns to render final judgement and deliver man into eternal paradise. The emphasis here is on eternity and final resolution to earthly problems. In the highly heterogeneous Buddhist tradition, similar narratives do exist, but they are always foregrounded on the idea of kalpic cycles, the slow turn of millennia by which the whole of reality revolves (Marra, "The Conquest of Mappō" 325).

In addition to desire and time, the game also has a greater emphasis on the hollowing process. This is most clearly personified in the character Lucatiel of Mirrah 
(rukatieru no miraa). Lucatiel is a wandering knight you encounter who will occasionally aid you in your quest. You meet her periodically in different locations within the world as you progress, but during each encounter she loses more and more of her memories as a result of being afflicted with the curse of undeath. This terrifies her and she eventually confides in you:

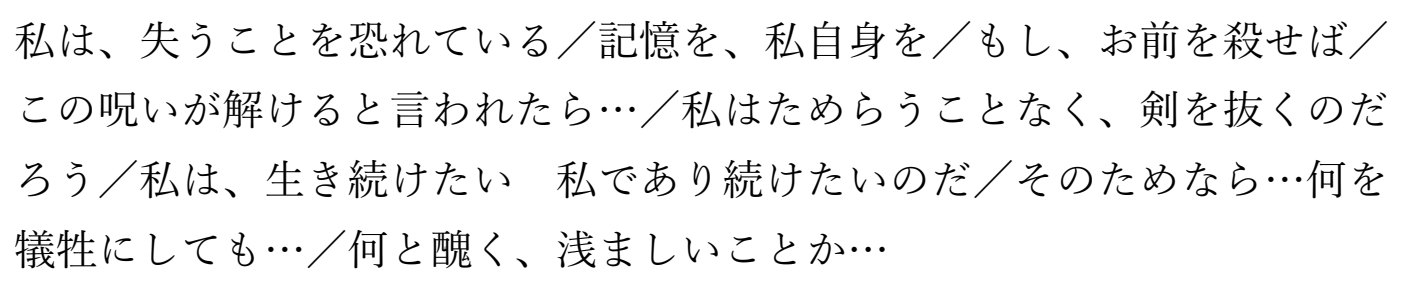

Loss frightens me no end. Loss of memory, loss of self. / If I were told that by killing you, I would be freed of this curse.../ Then I would draw my sword without hesitation. / I don't want to die, I want to exist. / I would sacrifice anything, anything at all for this. / It shames me, but it is the truth. Sometimes, I feel obsessed... with this insignificant thing called "self" / But even so, I am compelled to preserve it./ Am I wrong to feel so? Surely you'd do the same, in my shoes? Maybe we're all cursed/ From the moment we're born (FromSoftware, Dark Souls II)

Eventually, towards the end of the game, Lucatiel turns hollow and will attack the player's avatar. Lucatiel's sentiments, and the undead curse in general, can be related to the Buddhist doctrine of No-Self, or Anatta. This idea is one of the primary metaphysical principles that structures Buddhist practice. The term refers to belief that there is no permanent, underlying substance within human beings that constitutes the self. The precise interpretation of this doctrine is a point of contention between sects, theologians and scholars, but the centrality of this concept across the vast spectrum of Buddhist traditions is equivalent to dukkha and anicca (impermanence). In general, the doctrine of No-Self asserts that what constitutes "self" is rather the flow of phenomena within 
consciousness, which merely constitutes the illusion of self. Attachment to this thing called "self," a delusion, is one of the primary sources of dukkha, and thus one of the primary obstacles to overcome in religious practice. As a character, Lucatiel embodies the suffering that arises when we cling desperately to our existence, to the thing called "self." This gives the fire of the dark sign a slightly different meaning. It marks the player's avatar as one stuck in the cycle of samsara, burning on and on without end.

\section{LORDS OF CINDER, HEIRS OF FIRE}

Though there are many Buddhist themes throughout the series, a specific link with mappō becomes clear at the end of the third game. It is in the third game that the metaphors present within the series' core conceptual motifs mature and crystalize into a devastating statement on the fundamental futility of keeping the structures of the old regime from fading into oblivion. It simultaneously channels the Buddhist eschatology of mappō while presenting a barren postmodern vision of the traditions and cycles designed to keep the world lurching forward. In the third game, mappō-consciousness and postmodernism are fused into a double vision. Correspondingly, the intro cinematic of the third game is far more apocalyptic in tone than the first one:

$$
\begin{aligned}
& \text { そうさね、そこはロスリック/火を継いだ、薪の王たちの故郷が、流れ着 } \\
& \text { く場所さね/だから巡礼者たちは北に向かい/そして、予言の意味を知る }
\end{aligned}
$$


のさ／「火は陰り」／「王たちに玉座なし」／継ぎ火が絶えるとき、鐘が

響き渡り／古い薪の王たちが、棺より呼び起こされるだろう／深みの聖

者、エルドリッチ／ファランの不死隊、深淵の監視者たち／そして、罪の 都の孤独な王／巨人のヨーム/けれどね／きっと王たちは、玉座を捨てる だろう/そして、火の無き灰たちがやってくる/名もなく、薪にもなれな んだ、呪われた不死/けれど、だからこそ/灰はのこり火を求めるのさね

Yes, indeed / It is called Lothric / where the transitory lands of the Lords of Cinder converge / In venturing north, the pilgrims discovered the truth of the old words: / "The fire fades and the lords go without thrones" / When the link of the fire is threatened, the bell tolls / unearthing the old Lords of Cinders from their graves...Aldrich, Saint of the Deep / Farron's Undead Legion the Abyss Watchers / The reclusive lord of the Profaned Captial, Yhorm the Giant / Only, in truth / the Lords will abandon their thrones / And the Unkindled will rise / Nameless, accursed Undead, unfit even to be cinder / And so it is, that ash seeketh embers. (FromSoftwareInc.; video clip)

Unlike the first game, there is no origin story here, no primordial scenes from the dawn of time, no battles between new and old gods, only a crumbling kingdom sinking into the sands $(0: 15)$. Horrifying "pilgrims" with obscene boulders strapped on their withered backs collapse into the sand and perish (0:28), and the gods here are all already spent and corrupted, reanimated as Lords of Cinder by the tolling bell. The father-god is totally absent, but his title from the last game remains. Just as lord Gwyn was referred to as takigi no ou during the final boss encounter, now we have this appellation in the plural. Several lords are named, and this again functions as an act of foreshadowing. These are the foes to be defeated, foes with enormous souls that will be used to re-link the fire. Indeed, when you defeat these named entities, unlike the first game where the text "YOU DEFEATED" (sic) appears across the screen, this time "HEIR OF FIRE DESTROYED" will appear when a lesser boss is defeated, and "LORD OF CINDER FALLEN" will appear when one of these named entities from the introduction is eventually slain. 
In the first game, when the player encounters Lord Gwyn for the first time, the name that appears above his health bar gives him the title Lord of Cinder in the English localization, and takigi no ou in the original Japanese. However, there is a conceptual issue that needs to be resolved here as the game has linked the Japanese term takigi with the English term cinder, and though these terms are certainly related, they are different in important ways that complicates the metaphor of linking the fire. It is easy to dismiss this discrepancy as merely a thoughtless gloss of nuance on the part of the English localization team but the third game has taken this discrepancy and codified it. The English voice acting in the opening cinematic and the new message that appears after defeating the bosses are part of the original Japanese version of the game, and so the words cinder and takigi must be interpreted together.

The word cinder can be used scientifically to refer to volcanic rock, or in a looser, more colloquial sense to refer to an ember of charcoal or coal. In the context of the game, cinder is clearly meant to refer to the latter as it supports the central metaphorical motif of "linking the flame." When fires burn out, wood cinders remain smoldering beneath the white ash. These can be used to rekindle a fire by unearthing them and placing fresh kindling atop them. Embers can remain burning for a long time after a fire has gone out, and have been known to cause forest fires and other accidents. When we relate this to the events of first game, the cinder metaphor seems to have a very clear correlation. In the first game, your job as "chosen undead" is to find the still glowing embers (the four great souls) beneath the ash of the dead world, and use them to rekindle the fire of the world. 
The word takigi, on the other hand means fuel for a fire, but specifically refers to wood that has been cut down and turned into a form of charcoal using kilns.

There is perhaps a historical resonance with Japan's own reliance on wood charcoal that can be gleaned here. The reliance on wood charcoal as a fuel source was a major source of deforestation throughout Japan's premodern history (Conrad, 9). The general over-reliance on wood reached a point of crisis in the Edo period that ultimately led to serious economic and political problems. This prompted the shogunate to develop sophisticated forestry policies and new silvicultural techniques. Charcoal as a fuel source was an essential part of pre-modern Japanese society, and because it burns much more efficiently, it is easier to control and produces a much hotter flame. To create it, wood must be placed within a kiln that must be heated by burning ordinary wood. This means the normal wood consumed to make this fuel source increase exponentially. The trade-off is the immense utility gained from charcoal since untreated wood does not burn hot enough to smelt steel or other important metals. For example, it required 163,000 cubic feet of charcoal to create the massive Buddha statue at Todai-ji (MacDonald). Thus, the production of charcoal has important civilizational implications. However, the more civilization grows, the more this production cannot be sustained. Eventually, it will leave a barren wasteland, and shortages will cause serious problems for a society dependent of this fuel source. The idea that gathering the fuel to keep the fire of our age burning ever brighter saps the world of its vitality and leads to disasters would certainly seem to be present in Dark Souls. It has pertinence to our own times. This sort of narrative is common to contemporary environmentalist concerns such as global warming or peak-oil 
which also carry apocalyptic overtones. In the Japanese case, concerns over the doubleedged nature of energy consumption is reflected in the fierce debate between the right and the left over nuclear energy in the wake of the incident at Fukushima.

The second point that infuses this term, takigi, with special meaning is the idea that in order for it to become a fuel source, it must be prepared by treating it with fire. Each game is like a process in which the player's avatar is prepared like charcoal, through the ordeals that the player must face, and through the kindling of the flame of desire that animates the human psyche. This is true from the narrative perspective (i.e. your character as "cursed undead" is hungry for souls) but also in ludic terms. Indeed, in order for a game to succeed as a work, it must successfully fan the flame of the player's desire to continue playing through its design.

Only by stoking the player's avatar's internal flame through constant development is the avatar ready to be used as a fuel source to power the new age. The dual reading of takigi as cinder, that is to say as a hot ember lurking beneath the ash of the dead age, and as charcoal specially prepared to create a more powerful fire for a new age, affords an interesting interpretation of the actions of the player throughout the series. In each game, the player's job is to rekindle the world by gathering the embers that lay hidden beneath the ash of a dead world (the great souls of the corrupt, old lords) so that they can use them to re-ignite the world using themselves as a specially-prepared fuel source.

In the first game, we are introduced to the character of Gwyn as "The Lord of Sunlight" (taiyō no hi no ou), but when we encounter him in his abominable, hollowed state his title has been changed to Lord of Cinder (takigi no ou). As the main progenitor 
of the age of fire, it is easy to represent him as the still smoldering cinder of the flame, a shadow of the past that must be put to use to rekindle the world. However, we could equally read his unwillingness to let go of the flame and his long isolation within a giant kiln, as a form of self-desiccation. His being has been prepared over the centuries in a kiln to function as a catalyst for a new fire. The serpents demand you succeed his throne, and should you do so, that is exactly what occurs.

Your trials have prepared you to act as charcoal, as catalyst for all the kindling you have gathered, i.e. all the souls you have accumulated. However, the preparation of charcoal always implies a net loss of material for the sake of a more powerful flame. When we read into the word takigi this dual meaning of cinder (past)/charcoal (future) a cycle appears, but it is a cycle of diminishing returns. Each re-linking of the fire draws upon dwindling resources, and thus each re-incarnation of the kingdom (new name and new lords) is merely a degraded replica. If this is merely implied in the first and second game, the third game cements it. It is perhaps possible that the first game can be still be read in terms of a traditional western myth of revivifying the old regime with new blood. However, the ending of the third game can only be understood in terms of Azuma's postmodernism and mappō, the dwindling cycle.

This reading of the game is compounded when we compare the final boss encounter of the first game with the third one. Once the player has gathered all the heads of the lords of cinder and assembled their heads on their thrones, a pathway opens yet again to the Kiln of the First Flame (saisho no hi no ro). This is where Gwyn is confronted in the first game, but the area appears to be the nightmarish waste bin of a 
thousand bygone eras rather than a giant kiln. High up in the sky, a flaming circle frames a black abyss, resembling the dark sign but now as a hellish, solar eclipse (Yottinokoya 1:47; videoclip). It pours down a stream of fire upon the earth somewhere beyond the distant horizon. All around you are massive citadels piled up on each other in a colossal broken heap that spiral impossibly upward, high into the air (0:48). They seem to be the ruined aggregate of ages, the twisted wreck of all the prior incarnations of "the kingdom": Lothric, Londor, Drangleic and a thousand nameless ones in between. But who awaits within the kiln this time around? Unlike the lords you defeated to get here, it has no name, it is merely "Soul of Cinder" (ó-tachi no keshin). The localization here is actually quite a significant departure from the original Japanese. A much more appropriate translation would be "Incarnation of Lords" or "Avatar of Kings." The term keshin has the general meaning of incarnation, but in the Japanese Buddhist tradition also has a specific reference to a manifestation of the Buddha. ${ }^{13}$

This last boss encounter is not unlike the avatar you created for yourself to inhabit this world. It too is an avatar without any meaningful relation to the world, just a vehicle of some outside will. It is simply a symbol of all those heroes that have linked and relinked the flame to keep the sputtering flame of the ages alive, but is a monstrous being devoid of substance. It is just an empty suit of armor, a puppet of this ritual of the linking the flame. This is reinforced by the powers and attacks patterns it possesses. The other bosses in the games are totally other from the player character. Their powers, abilities and

\footnotetext{
${ }^{13}$ The term 化身 is a synonym for the term 応身 which refers to the third incarnation of the Buddha, Nirmaana-kaaya.
} 
aesthetics are totally distinct, but the Incarnation of Kings utilizes techniques and abilities that mimic your own (1:53-14:50). His attack patterns all reflect different routes a player can take when they develop their character over the game: wizard, dexterous rogue, stalwart knight, chaotic pyromancer, etc. In this sense, it is the ultimate embodiment of "ergodic irony" as it personifies all the paths not taken, the paths of other would-be heroes all mashed up into an empty monstrosity.

When this faceless entity, the aggregate of sacrificial heroes is defeated, you may choose to link the flame just as in games past. Where there are only two different endings in the first game, there are now four, each an increasingly more apocalyptic ending than the last. There are no "good" endings this time around. The first ending has the player linking the flame just as instructed. Just like the first game, the player's avatar reaches into the bonfire and his hand ignites. But instead of this fire spreading over his body, culminating in a massive conflagration, it simply swaddles the avatar in a dull mantle of flame, flickering dimly like a dying ember amidst a sea of ash (taraco tea 0:50-1:29; video clip). It seems that the re-linking of the flame has yielded weaker and weaker flames with each re-linking, and in this final act of the series, the ritual itself appears to be ineffectual. Once the flames have wrapped themselves around the player's avatar, they sit down by the bonfire to rest in a dejected, world-weary fashion. This flame does even have the power to consume the one linking it. This ending clearly stands in stark contrast to the seemingly heroic, "good" ending of the first, and solidifies the games connection to mappō-consciousness. This age is simply too degraded for this heroic ritual to have any 
purpose or meaning. In the third game, we are well past $z \bar{o} h \bar{o}$ (the age of semblance) as the ritual does not even look the part.

The other three endings are not categorically different. In the second ending, the player can summon the firekeeper - a character met at the beginning of the game - to the kiln and allow her to extinguish the flame (3:32-5:20). In the third ending, through some obscure and unintelligible ritual, the player fixes this twilight age in place and becomes a lord of the undead (1:55-3:14). This ending is particularly hard to achieve as it requires you complete a complex series of secret tasks that would be nearly impossible to discover on your own without recourse to the internet. The fourth ending is particularly cryptic. It begins just like the second ending, but as the firekeeper goes to extinguish the flame you may strike her down. Should you do so, a cut scene will began where the character's avatar knocks the firekeeper to the ground, places his boot upon her head and reaches down to retrieve a burning ember from her hands (6:45-7:30). When this happens, the old woman, who has been the narrator throughout the intro cinematic of all three games, speaks:

名も無く、薪にもなれなんだ、呪われた不死／けれど、だからこそ／灰は 残り火を求めるのさね。

Nameless accursed undead, unfit even to be cinder/ and so it is/ that ash seeketh embers $(7: 00-7: 23)$

This statement repeats a line in the opening, where the character is referred to as an accursed undead, unfit even to be cinder. This also reflects a further degradation of the games' central motifs as you were referred to in the first game as a "chosen undead". After this wanton act of unintelligible cruelty, your avatar lifts the stolen ember into the 
stream of fire that pours from the burning eclipse in the sky as if making an offering. The words of the narrator seem to suggest that it is precisely the unworthiness of the player character as "ash" that makes them crave "embers."

As is the nature of both the medium and the creators of this series, there is no canonical ending. This is in keeping with the postmodern consciousness that infuses the game, and perhaps games generally as multiple endings are a norm of the medium. In the final analysis, no concrete interpretation of the narrative can be derived from within the context of the game itself. Each ending is only suggestive, not conclusive. Its meaning almost entirely contingent on the impression received through our perception of its meager, concrete textual elements and its affective features: the way it looks, the way it sounds, the way it feels, etc. What is the meaning of the avatar's cruelty toward the firekeeper in the fourth ending? It is not clear. What is clear through the gestures and the overall tone that some act of violation is occurring between these characters. In all four endings, your journey to re-link the fire and presumably dispel the undead curse, does not end in a manner that even remotely suggests this goal has been accomplished. Perhaps the most postmodern feature of the game world is the very fact of these "choices" and their entirely opaque meaning. Certainly, no ending can be selected as canonical, and even if we could, its meaning would be indecipherable. The only concrete aspect of the series is a constellation of affective features, motifs and game design elements that keeps it recognizable as a series. This constellation all points to the hopelessness of the future, the sins of the past and the suffering of living through the present. The pattern that emerges is that the ritual of heroism intended to revive the world is revealed as nothing 
more than an empty cycle by which desperate souls cling to dying embers and further convolute the structure of reality. The grand narrative that infuses this ritual with its original meaning is so obscure it cannot even be detected anymore. 


\section{CONCLUSION}

What I have argued here is that Dark Souls series, and in particular the third entry, is a cultural artifact that reflects postmodern consciousness in contemporary Japanese society. The postmodern anti-narratives espoused by thinkers such as Osawa and Azuma, the revitalization of far-right ideology (Nihon o torimodosu), the phenomenon of extreme social withdrawal (hikikomori, sōshoku danshi) all reflect a deep anxiety provoked by internal acts of terrorism (Aum Shinrikyō), the declining birth rate, deterioration of welfare systems and unstable infrastructure (Kobe, Fukushima). Postmodern consciousness is the feeling that emerges when the ground one stands on, literally and socially, seems at risk of evaporating. The Dark Souls series is also an expression of this anxiety, but it is possibly the most potent expression of contemporary anxiety as a concrete, cultural artifact. Its great success and canonization as one of the greatest series of all time, despite its rejection of industry best-practices, would seem to indicate that its aesthetics and design have touched upon a common feeling amongst the many millions that play video games.

So how can we summarize the postmodern consciousness of Japan, which in so many ways seems to be a consciousness spreading like wildfire all the over the postindustrial West? One way to think about it is that postmodern consciousness is simply a kind of pessimistic mood. It is the general sense that our aspirations will amount to nothing, that the project of modernity has failed, and that the notion that individuals can take meaningful steps towards their ideals, to say nothing of the human race, is a sad joke. It is the fear that contemporary life is somehow inferior to the past, possibly even 
pathetic. Indeed, the idea that society is progressing somewhere is a deeply unfashionable notion. Critiquing the aspirations of modernity as dangerous naivete has become a perfunctory component of philosophy or literary criticism of nearly any stripe. Beyond working to support the validity of my interpretation, I hoped also to demonstrate-if only in a preliminary way - that postmodern consciousness itself is also cyclical. It is merely a symptom of instability as society goes through transitions towards strange, new eras. Such pessimistic moods, or apocalyptic moods, are like growing pains when new paradigms of social organization struggle to emerge beneath the surface of a decaying order. However, I also wish to suggest that this pessimistic mood I have labeled postmodern consciousness is just that: a mood. Its reality is contingent on how much we are willing to indulge it.

With this in mind, I take seriously Osawa and Azuma's diagnosis of the psychological, or perhaps spiritual, problems afflicting Japanese society today. The way people feel, regardless of what is real, can drive them towards self-destructive behaviors. This can have very serious consequences for society as a whole, even when such thinking is only embraced by a minority. The actions of the Aum were perpetrated by a tiny group, but they still managed to damage something at the core of Japanese society. However, I reject the postmodern prognosis - in particular Azuma's prognosis - that the shift away from traditional narrative in popular culture is evidence that people have abandoned ideals in a general sense, and that we are all fated to withdraw into techno-epicureanism where everyone is reduced to slave of their own fetishes. 
That is merely one direction that some are going, and even this is debatable. In contrast to other popular mediums like manga and light novels, video games have at their core the demand to solve a series of problems. However artificial and remote from everyday life this demand may be, it is nonetheless a willing submission to undergo difficulties and overcome a challenge. On an extremely basic level, the willingness to undergo difficulties to solve a particular problem or overcome a particular challenge underpins all human endeavor. There is an odd disconnect between the vision of hopelessness in the narrative and the patience and skill required in the act of getting through the game.

Amongst video games, the Dark Souls series represents a batch of particularly challenging problems. It begs the question: why go through such a grueling series of challenges if there is no confirmation of your efforts? What is the take away? The answer can only be that the process itself is worthwhile, that the act of play itself is its own source of spiritual sustenance. However, play is much more complicated than having fun. As Aarseth and others have pointed out, ergos, that is to say "work," is essential to the medium of video games. Dark Souls is certainly a game where ergos and ludos are intextricably bound together. Of course, one does not play Dark Souls to work in the sense that one makes a living (excepting some entrepreneurial Youtubers). However, to say that playing Dark Souls is simply for fun effaces something absolutely crucial about the experience of the game. The kind of "fun" in Dark Souls is the kind one associates with climbing mountains, running marathons or anything that requires sustained effort over a long period of time: painful, difficult and only satisfying at the end for a brief 
moment before one willingly dives back into the same challenge again. Rather than describe these activities as fun, we say they are satisfying, and that is precisely what it feels like to overcome the challenges in Dark Souls.

The sociologist Roger Callois identifies games as the crucible where cultural reflexes and habits are developed (Callois, 83) If that is the case, what sort of cultural reflexes are developed when one plays a game like Dark Souls? The answer to this question may be beyond the scope of this paper, but it is safe to say that Dark Souls encourages us to embrace challenge so that we may be rewarded with grand vistas that are as hellish as they are sublime, infused with a terrifying beauty. This is perhaps the most important reward motivating the player to move forward, the reward of something beautiful to behold, and there can be no doubt for all its darkness and grotesqueness, each entry in the Dark Souls series is singularly beautiful in its visual presentation.

Dark Souls is a deeply complex and syncretic game that draws from Japan's present and past, but it all works to express a profound sense of anxiety about the possibility of self-actualization, progress and community when people start to question the main ideas underpinning their society. The complex interweaving of gameplay, narrative and aesthetic all cohere to form a potent expression of postmodern consciousness where the character is alone in an ailing world surrounded by hostile others in a situation they don't understand. The Buddhist metaphysics incorporated in the game further suggest that the quest to rectify this situation by performing a ritual of sacrifice and revitalization, is ultimately meaningless and even corrupt. In this sense, 
Dark Souls speaks directly to the great fear underpinning postmodernism; no matter how we seek to stave off oblivion, ultimately, it may just be out our hands.

However, there is a certain Nietzschean promise in games that is also reflected in Dark Souls - the promise of self-overcoming through agonistic struggle. I take seriously the postmodern diagnosis that a deterioration of traditional societal narratives has created disturbing patterns of self-destructive behavior, but I do not agree with their prognosis. Nor do I agree with their claim of historical uniqueness or even that traditional faiths, creeds, and narratives cannot be updated or evolved to meet the needs of the culture. I think that Japan has been here before. Postmodern consciousness is likely to be little more than a psychic stress — albeit a serious one — that people undergo when society goes through a major structural shift and the narratives of old structures lose coherence. It is destined to cycle back to a mood of optimism as they forms settle into concrete shapes. Things rarely stay the same for long — for good or for ill—and the fact of the matter is wherever we happen to be, no one really knows what's going to happen. That's how the future works. It's unknown, and only ideological dogmatism tries to fix it firmly in place; unchanging like the past. We must have the courage to be open to what happens next. 


\section{REFERENCES}

\section{$\underline{\text { PRINT AND WEB ARTICLES }}$}

Aarseth, Espen. Cybertext Perspectives on Ergodic Literature. Baltimore, MD, Johns Hopkins University Press, 1997.

Aarseth, Espen "“Define Real, Moron!: Some Remarks on Game Ontologies." Günzel, Stephan

Aarseth, Espen. "Doors and Perception: Fiction vs. Simulation in Games." Intermédialités, vol. 1 no. 9, 2007, pp. 35-44.Liebe, Michael Mersch, Dieter (ed.). DIGAREC Keynote-Lectures 2009/10. Potsdam: Universität Potsdam. 2011. 50-68. (DIGAREC Series).

Arsenult, Dominic, et al. "In the Frame of the Magic Cycle." The Video Game Theory Reader 2, Routledge, New York, NY, 2009, pp. 109-129.

Azuma, Hiroki. Doubutsuka Suru Posutomodan: Otaku Kara Mita Nihon Shakai. Tokyo, Kodansha, 2011.

Baudrillard, Jean. Simulacara and Simulation. Translated by Akiko Takehara. Tokyo, Hosei Daigaku Shuppankyoku, 2008.

Bloom, A. "The Sense of Sin and Guilt and the Last Age [Mappō] in Chinese and Japanese Buddhism.” Numen, vol. 14, no. 2, 1 July 1967, pp. 144-149.

Callois, Roger. Man, Play, and Games. Urbana, University of Illinois Press, 2001.

Campbell, Joseph. The Hero with a Thousand Faces. Novato, CA, New World Library, 2008.

Dower, John W. Embracing Defeat: Japan in the Aftermath of World War II. New York, W. W. Norton, 2000.

Frasca, Gonzalo. "Simulation versus Narrative: Introduction to Ludology." The Video Game Theory Reader, edited by and Bernard Perron and Mark J.P. Wolf, Routledge, 2003. pp. 222-233.

Gerald G., Marten. "Environmental Tipping Points: A New Paradigm for Restoring Ecological Security." Journal of Policy Studies (Japan), vol. 20, July 2005, pp. 75-87., www.ecotippingpoints.org/resources/publication-journal-of-policystudies.html. Accessed 20 May 2017. 
Hane, Mikiso. Modern Japan: a Historical Survey. Boulder, CO, Westview Press, 1986.

Hazaa, Jiko. "The Characteristics of Japanese Tendai." Japanese Journal of Religious Studies, vol. 14, no. 2-3, Jan. 1987.

Herbig, Paul A. “Japan's Shinjinrui: the New Breed.” International Journal of Social Economics, vol. 22, no. 12, 1974, pp. 49-65., doi:http://dx.doi.org/10.1108/03068299510104750.

Huizinga, Johan. Homo Ludens: A Study of the Play-Element in Culture. Angelico Press, 2016.

Jenkins, Donald, and Lynn Jacobsen-Katsumoto. The Floating World Revisited. Portland, OR., Portland Art Museum, 1993.

Juul, Jesper. Half-Real: Video Games between Real Rules and Fictional Worlds. Cambridge MA, The MIT Press, 2011.

Kasulis, Thomas P. "Shin Buddhist Ethics in Our Postmodern Age of Mappō." The Eastern Buddhist, vol. 33, no. 1, 2001, pp. 16-37.

Kevingifford. "Dark Souls 2 Developer: If Dark Souls Was Set in the North Pole, This One Would Be in the South Pole.” Polygon, 19 Dec. 2012, www.polygon.com/2012/12/19/3783452/dark-souls-2-staff-discuss-the-vgatrailer-and-what-having-real. Accessed 21 May 2017.

Kietzman, Ludwigk. "Half-Minute Halo: An Interview with Jaime Griesemer." Engadget, 14 July 2016, www.engadget.com/2011/07/14/half-minute-halo-aninterview-with-jaime-griesemer/. Accessed 18 May 2017.

Kojeve, Alexander. Introduction to the Reading of Hegel: Lectures on the Phenomenology of Spirit. Translated by Kozuma Tadashi. Tokyo, Kokubunsha, 1987.

Miller, Laura, and Bruce White. "Youth Fashion and Changing Beautification Process." Japan's Changing Generations: Are Young People Creating a New Society., Edited by Gordon Mathews, Routledge, New York, NY, 2004, pp. 83-95.

Londo William. "The Idea of Mappō in Japanese Religion and History." Interdisciplinary Humanities, vol. 24, no. 2, Fall 2007, pp. 115-125.

Lenio, Olli Tapio. "Death Loop as a Feature." The International Journal of Computer Game Research, vol. 12, no. 2, December 2012. 
Macdonald, Deanna. "Todai-Ji." Khan Academy, www.khanacademy.org/humanities/apart-history/south-east-se-asia/japan-art/a/todai-ji. Accessed 20 May 2017.

Martin, Paul. "Ambivalence and Recursion in Castlevania: Symphony of the Night." Eludamos Journal for Computer Game Culture, vol. 5, no. 1, 2011, pp. 71-90.

Marra, Michele. "The Conquest of Mappō Jien and Kitabatake Chikafusa." Japanese Journal of Religious Studies, vol. 12, no. 4, Jan. 1985, pp. 319-341.

Marra, Michele. “The Development of Mappō Thought in Japan. ” Japanese Journal of Religious Studies, vol. 15, no. 1, 1 Mar. 1988, pp. 25-54.

Olson, Kyle B. Aum Shinrikyō: Once and Future Threat? Emerging Infectious Diseases, vol. 5, no. 4, Aug 1999, pp. 413-416. wwwnc.cdc.gov/eid/article/5/4/990409 article

Osawa, Masachi. Fukanousei No Jidai. Tokyo, Iwanami Shoten, 2008.

Osawa, Masachi. Kyokou No Jidai No Hate. Tokyo, Chikuma Shobo, 2009.

Sharp, Andy. "Abe Taps Shiller Insights on Breaking 'Shrunken Mindset'.” The Japan Times, www.japantimes.co.jp/news/2014/05/20/business/economy-business/abetaps-shiller- insights-breaking-shrunken-mindset/\#. WSzF3GgrJPY. Accessed 29 May 2017.

Smith,Harvey, and Mathias Worch. "What Happened Here? Environmental Storytelling." Game Developer's Conference, 2010, San Francisco, Http://Www.gdcvault.com/Play/1012647/What-Happened-Here-Environmental, niemanstoryboard.org/stories/harvey-smith-on-environmental-storytelling-andembedding-narrative/. Accessed 18 May 2017.

Tanaka, Motoko. Apocalypse in Contemporary Japanese Science Fiction. New York, Palgrave Macmillan, 2014.

Thanisarro Bikkhu, translator. "Adittapariyaya Sutta: The Fire Sermon.” Accesstoinsight.org, www.accesstoinsight.org/tipitaka/sn/sn35/sn35.028.than.html. Accessed 19 May 2017.

Vella, Daniel. "No Mastery Without Mystery: Dark Souls and the Ludic Sublime." The International Journal of Computer Game Research, vol. 15, no. 1, July 2015.

Zizek, Slavoj. How to Read Lacan. New York, W.W. Norton \& Co., 2007. 


\section{$\underline{\text { VIDEO }}$}

13222F. “DARK SOULS プラチナ獲得予想 150 時間越え？.”YouTube, 4 Oct. 2013, www.youtube.com/watch?v=oH6O2UUlkX0\&t=95s\&spfreload=10. Accessed 20 May 2017.

Clubfc. “DARK SOULS | ダークソウル ED 闇の王.”YouTube, 10 Oct. 2011, www.youtube.com/watch?v=bXvnzq9CMlc. Accessed 20 May 2017.

Entropy622. “DARK SOULS Part 22 最初の火の炉.”YouTube, 7 Sept. 2012, www.youtube.com/watch?v=I_nrTwnQb7c\&t=593s\&spfreload=10. Accessed 20 May 2017.

FromSoftwareInc. “DARK SOULS III オープニングシネマティックトレーラー 【2016.2】."YouTube, 10 Feb. 2016, www.youtube.com/watch?v=Na5ZwyLVli8\&t=104s. Accessed 21 May 2017.

Karz. “Dark Souls Opening Movie : ダークソウル オープニングムービー.” YouTube, 22 Sept. 2011, www.youtube.com/watch?v=up9qZYhSPMw. Accessed 19 May 2017.

Menuez, Paolo. “Apocalyptic World.” YouTube, 5 May 2017, www.youtube.com/watch? $\mathrm{v}=\mathrm{hbEuDmVxSkU}$.

Mizu8823. “ダークソウル・淡々初見プレイ 119.フラムト.”YouTube, 30 July 2013, www.youtube.com/watch?v=JdZ7rAIqn0U\&t=390s\&spfreload=10. Accessed 20 May 2017.

NamcoBandaiGamesEU. "Dark Souls - X360 / PS3 - Hardcore Trailer.” YouTube, 11 Oct. 2011, www.youtube.com/watch?v=r3HdfzC7Shg. Accessed 29 May 2017. 
PikaRay3821.“［ダークソウル 2］エンディング・玉座に進む宝座を去る・スタ ッフロール.”YouTube, 3 Oct. 2016, www.youtube.com/watch?v=RHmk7s2Zr30. Accessed 20 May 2017.

Taraco tea. “ダークソウル 3 全 3 種類+隠しエンディング DARK SOUL3 Multiple ED.” YouTube, 4 Apr. 2016, www.youtube.com/watch?v=MCCEGMjz7sw. Accessed 20 May 2017.

VaatiVidya. "Dark Souls 3 Lore of the Main Bosses." YouTube, 6 June 2016, www.youtube.com/watch?v=8ma-1-9zC3M. Accessed 18 May 2017.

\section{GAMES}

Dark Souls. FromSoftware, Namco Bandai, 2011.

Dark Souls II. FromSoftware, Namco Bandai, 2014.

Dark Souls III. FromSoftware, Namco Bandai, 2016. 


\section{APPENDIX: FIGURES}

Figure 1 : Bodhidharma crosses the Yang-tzi on a reed (left), Suzuki Harunobu's courtesan makes the same voyage wearing Bodhidharma's trademark red robes.
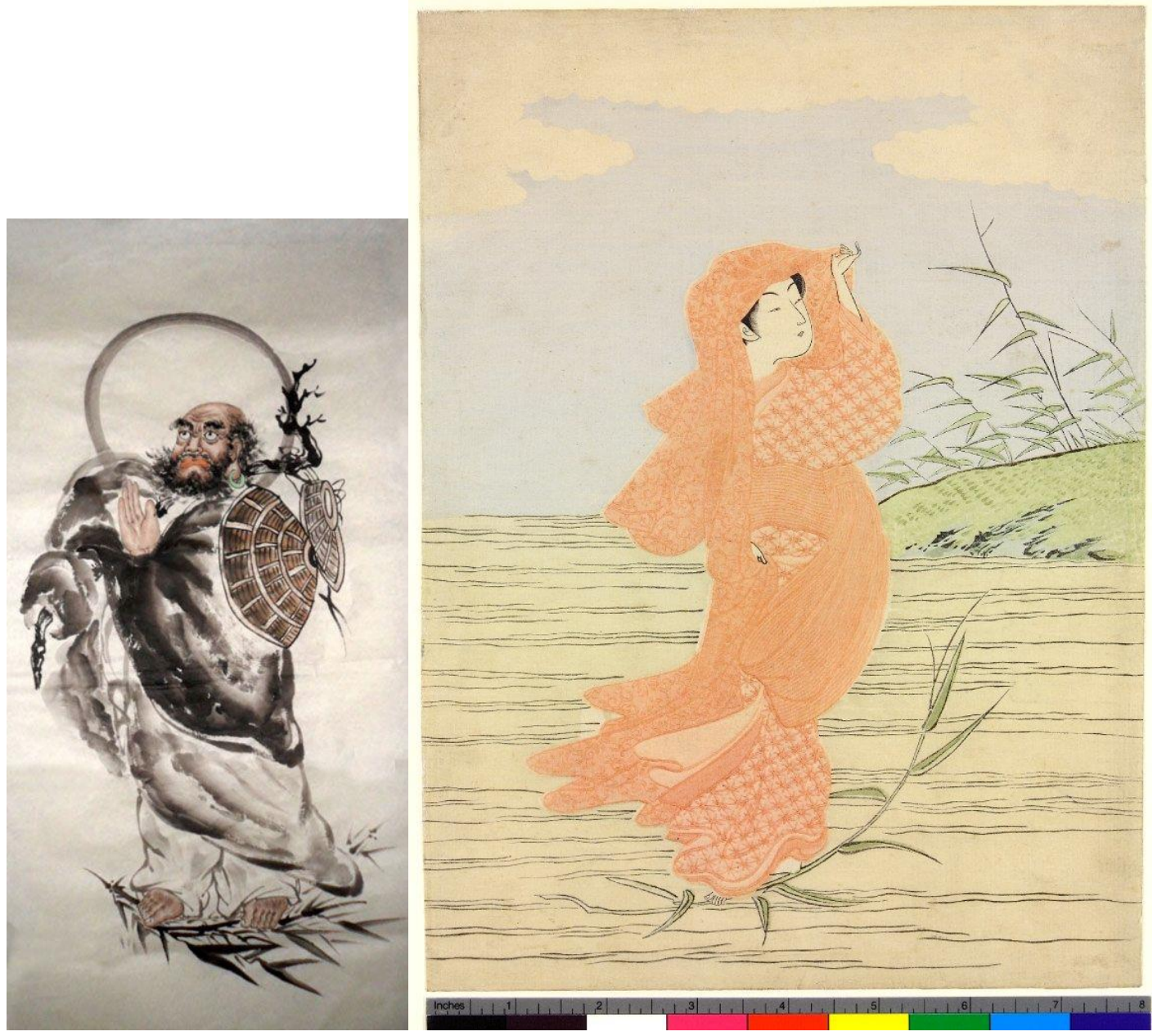
Figure 2: Iudex Gundyr from the opening section of the game in the Cemetery of Ash.

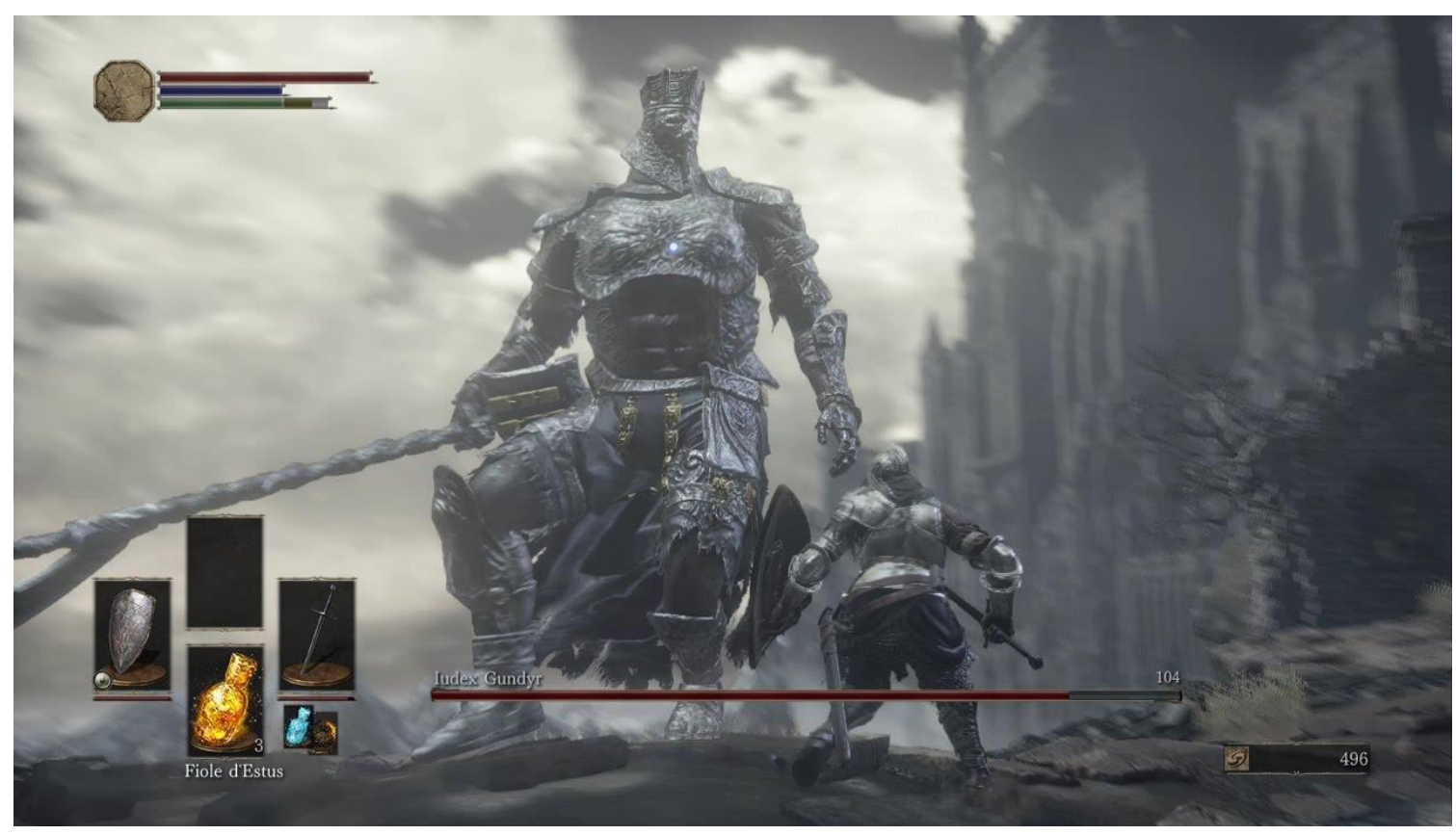

Figure 3: Champion Gundyr at the Untended Graves.

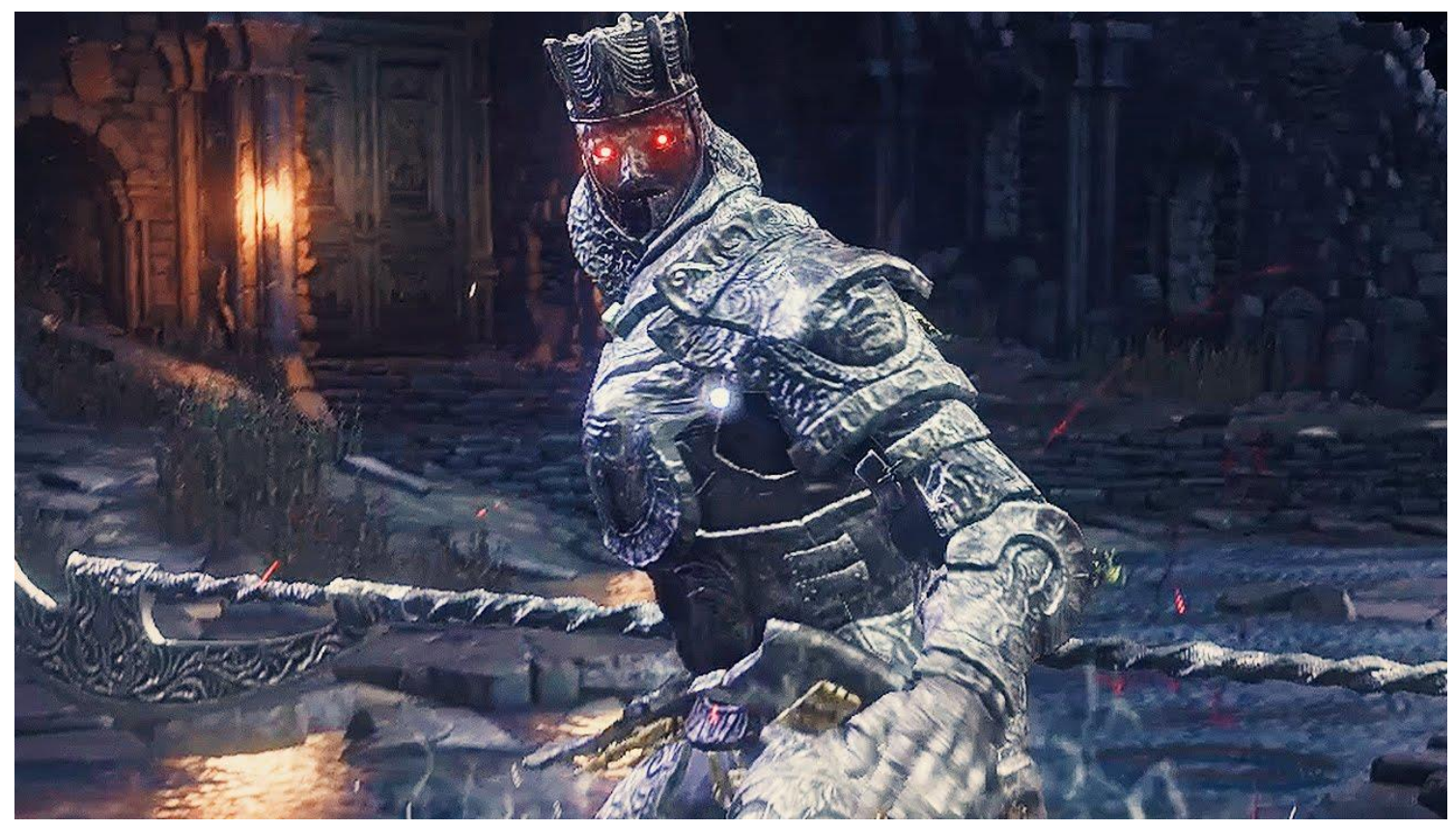


Figure 4: Icon of the Dark Sign as it appears in the character's inventory (top), a hollow from Dark Souls.
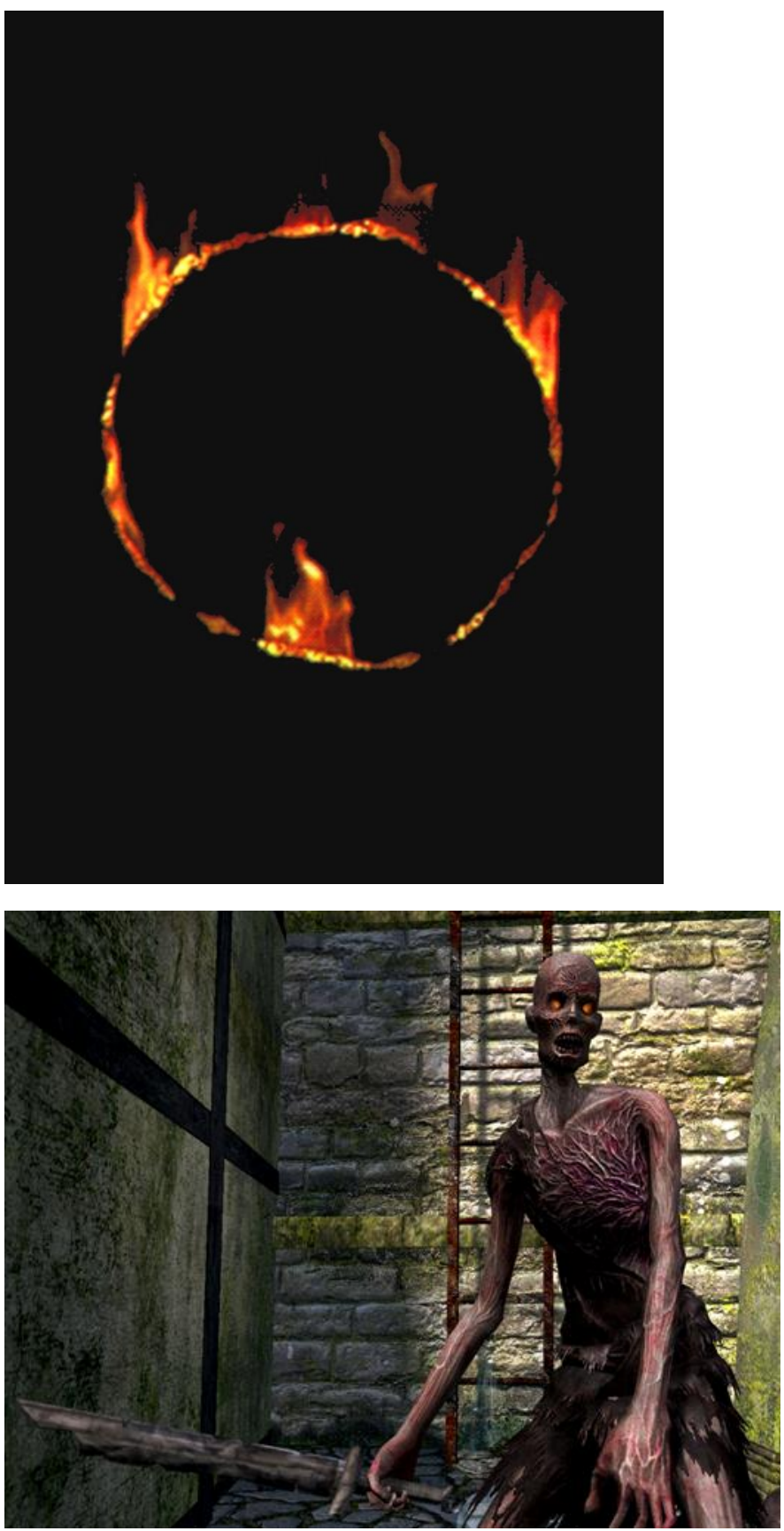
Figure 5: Promotional screenshot of a bonfire in Dark Souls 2

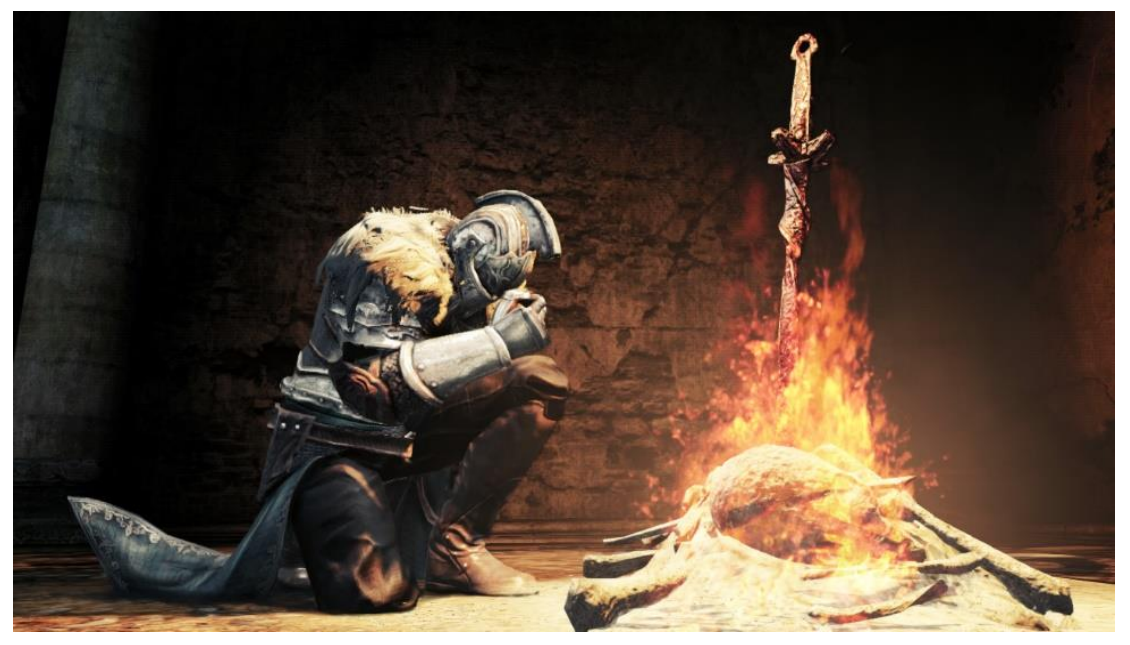

Figure 6: Typical Japanese depiction of a preta.

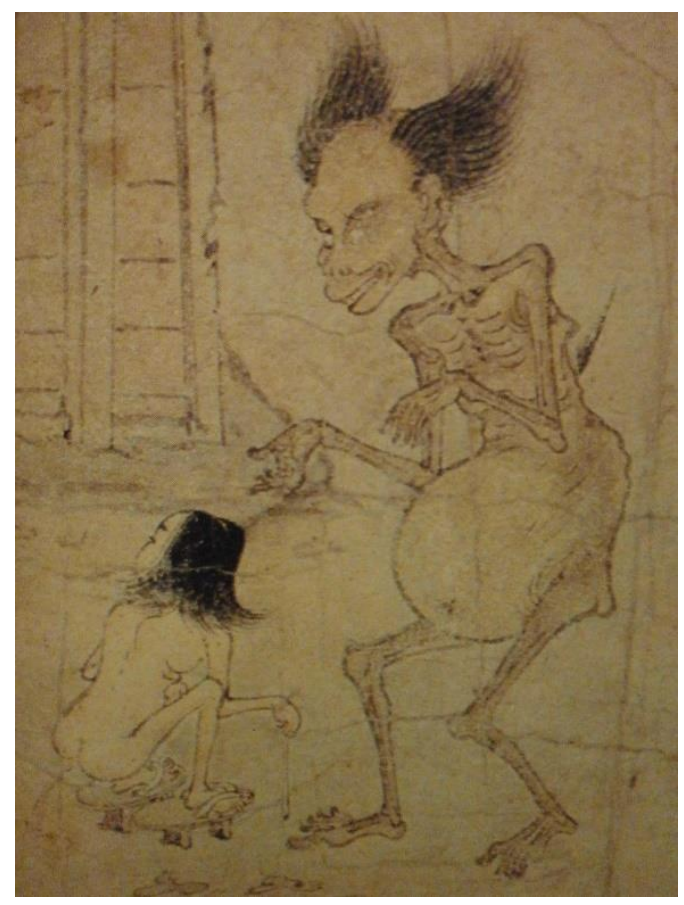


Figure 7: Gwyn Lord of Cinder (top), Gwyn Lord of the Sun
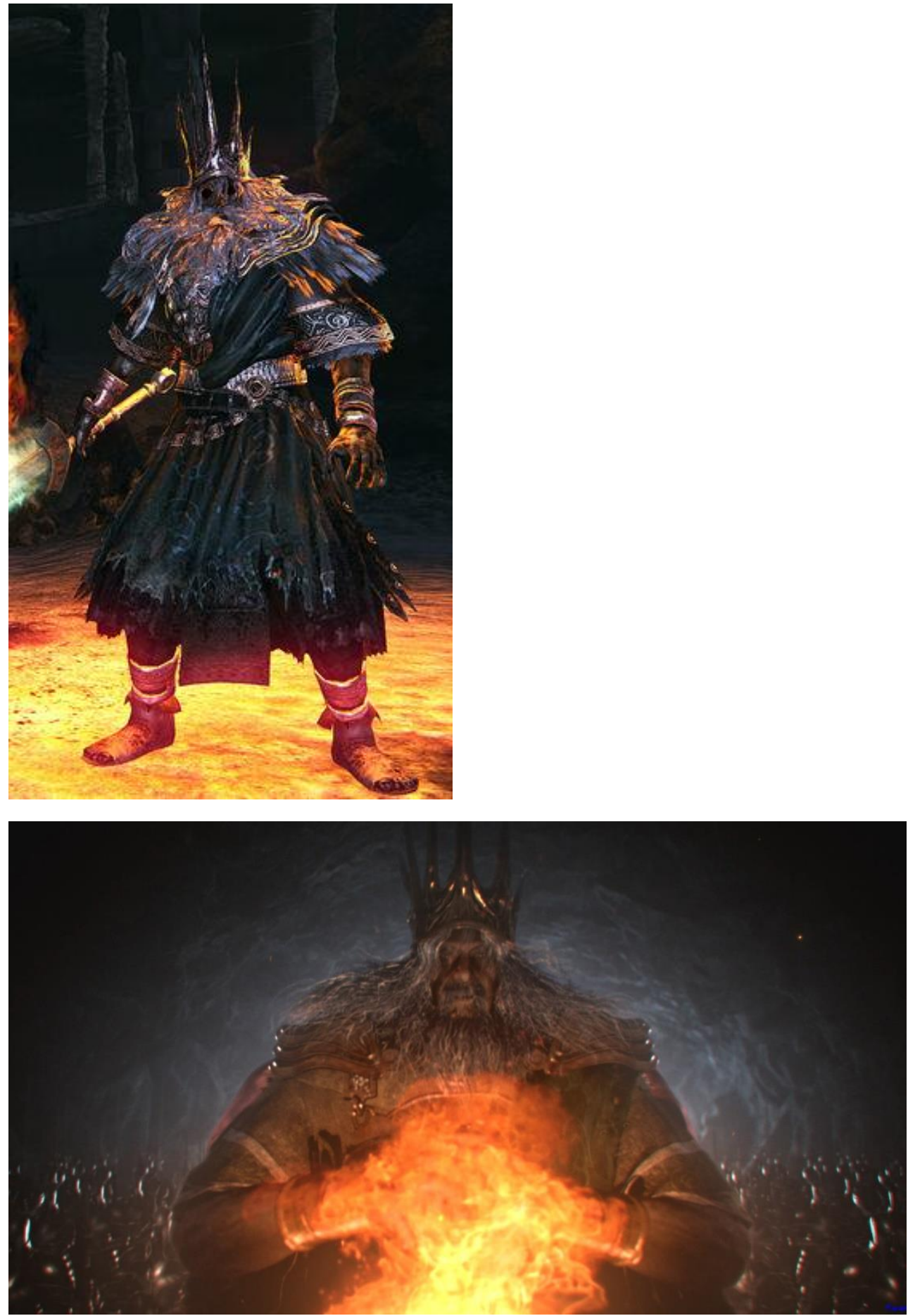